\title{
The New House Museum: How the Development of Modern House Museums are Changing the Philosophies and Standards of Interpretation and Preservation
}

Jillian Barto

West Virginia University

Follow this and additional works at: https://researchrepository.wvu.edu/etd

\section{Recommended Citation}

Barto, Jillian, "The New House Museum: How the Development of Modern House Museums are Changing the Philosophies and Standards of Interpretation and Preservation" (2012). Graduate Theses,

Dissertations, and Problem Reports. 821.

https://researchrepository.wvu.edu/etd/821

This Thesis is protected by copyright and/or related rights. It has been brought to you by the The Research Repository @ WVU with permission from the rights-holder(s). You are free to use this Thesis in any way that is permitted by the copyright and related rights legislation that applies to your use. For other uses you must obtain permission from the rights-holder(s) directly, unless additional rights are indicated by a Creative Commons license in the record and/ or on the work itself. This Thesis has been accepted for inclusion in WVU Graduate Theses, Dissertations, and Problem Reports collection by an authorized administrator of The Research Repository @ WVU. For more information, please contact researchrepository@mail.wvu.edu. 
The New House Museum:

How the Development of Modern House Museums are Changing the Philosophies and Standards of Interpretation and Preservation

Jillian Barto

\begin{abstract}
Thesis submitted to the
College of Creative Arts

at West Virginia University

in partial fulfillment of the requirements

for the degree of

Master of Arts

in

Art History

Examining Committee:

Kristina Olson, M.A., Chair,

School of Art and Design

Rhonda Reymond, Ph.D.,

School of Art and Design

Melissa Bingmann, Ph.D.,

Department of History
\end{abstract}

Morgantown, West Virginia

2012 


\begin{abstract}
The New House Museum:

How the Development of Modern House Museums are Changing the Philosophies and Standards of Interpretation and Preservation

Jillian Barto

This study discusses how the emergence of architecturally significant modern house museums has necessitated implementation of new philosophies guiding interpretation and preservation distinct from those governing historic house museums. Traditionally, many historic house museums' significance is the history that took place there, with interpretive themes presented to visitors being based on the historical background, and with preservation work directed at saving the historic material. With modern house museums, the significance is the architectural design, with interpretive themes and preservation or restoration efforts revolving around the building's design and the architect's intentions. With these modern architectural sites, the interpretation is about the architecture, and social history is used to support the architectural interpretation. Instead of preserving the historic material and allowing patina to show as at historic house museums, modern house museums have begun to concentrate on preserving the architectural design, staying true to the modern aesthetic rather than showing patina. The Kaufmann House (known as Fallingwater) (1934-39 in Mill Run, Pennsylvania), the Gropius House (1939 in Lincoln, Massachusetts), and the Farnsworth House (1945-1951 in Plano, Illinois) are three examples of modern house museums where the staff has adopted these new philosophies to be used as case studies in this thesis.

Modern house museums are an emerging type of house museum with more and more architecturally significant, Twentieth-Century homes opening to the public but, there are no set standards or professional practice literature for the staff of these sites to follow. This thesis addresses the differences between modern house museums and traditional historic house museums demonstrating the need for these new operational standards and offering examples from practices currently in use that provide the basis for developing such standards.
\end{abstract}




\section{ACKNOWLEDGEMENTS}

I would like to thank my committee members; Professor Olson, Dr. Reymond, and Dr. Bingmann; as well as Valerie M. Wright and Dr. Snyder for all their guidance and advice throughout this process. Without your help, this thesis would not possible. Your support and guidance has helped me get through graduate school and prepared me for my future.

I need to thank Justin Gunther, Whitney French, Peter Gittleman, and Wendy Hubbard for taking the time to meet with me and provide much of the information for this study, as well as the rest of the staffs at Fallingwater, the Farnsworth House, and the Gropius House for all their help.

I would also like to thank all of family and friends for being so supportive and understanding while going through this process; it means the world to me. I especially want to thank my parents who have put up with me and provided so much so I could get to where I am today. 


\section{TABLE OF CONTENTS}

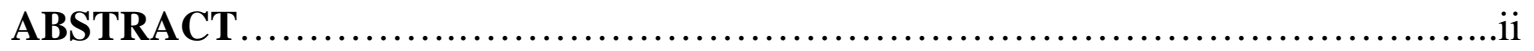

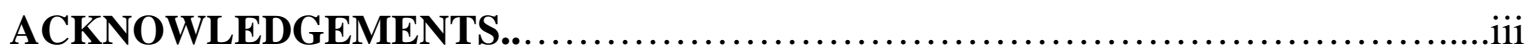

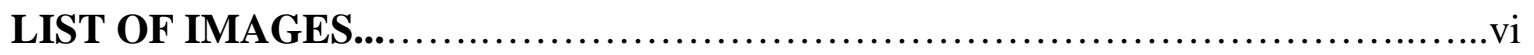

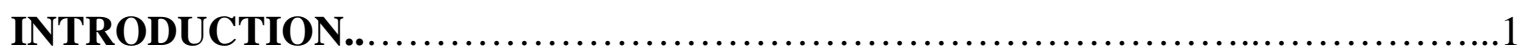

\section{CHAPTER ONE:}

A New Genre of House Museum.

Background of the Gropius House, Fallingwater, and

the Farnsworth House, and How They Became Museums.....................................15

Background of the Operating Institutions..................................

What Makes Modern House Museums and Traditional

Historic House Museums Different......................................20

\section{CHAPTER TWO:}

Architectural Interpretation of Modern House Museums.............................33

Tours: The Necessary Background Information.............................35

Architecture as Main Interpretive Theme...................................40

How Social History Interpretation Supports Architectural Interpretation..........49

Conclusion.............................................................55

\section{CHAPTER THREE:}

New Philosophies and Standards in Preservation of Modern House Museums............56

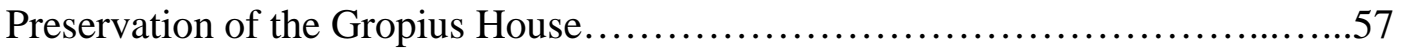

Preservation of Fallingwater...........................................64

Preservation of the Farnsworth House....................................70

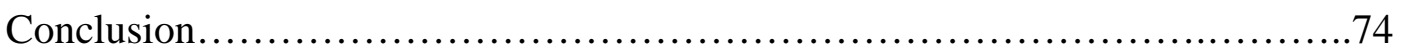

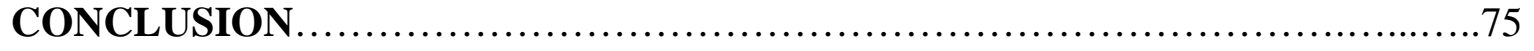




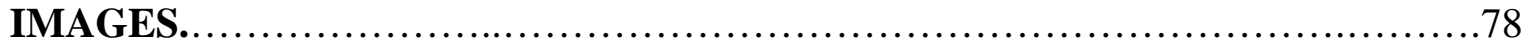

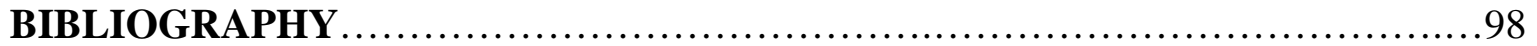




\section{List of Images}

Image

Page

1. The Gamble House, 1908

Charles and Henry Greene

Pasadena, California

2. The Gropius House, 1938

Walter Gropius

Lincoln, Massachusetts

3. Fallingwater, 1934-1939

Frank Lloyd Wright

Mill Run, Pennsylvania

4. The Farnsworth House, 1951

Ludwig Mies van der Rohe

Plano, Illinois

5. Mount Vernon, 1757-1799

George Washington

Mount Vernon, Virginia

6. Monticello, 1769-1782

Thomas Jefferson

Charlottesville, Virginia

7. Paris Opera House, 1857-1874

Charles Garnier

Paris, France

8. Chrystal Palace, 1851

Joseph Paxton

London, England

9. Eiffel Tower, 1899

Gustave Eiffel

Paris, France

82

10. Bauhaus, 1925-1926

Walter Gropius

Dessau, Germany 
11. Seagram Building, 1958

Ludwig Mies van der Rohe

New York City, New York

12. Vanna Venturi House, 1964

Robert Venturi

Philadelphia, Pennsylvania

13. Barcelona Pavilion, 1929

Ludwig Mies van der Rohe

Barcelona, Spain

14. Belle Grove Plantation, 1797

near Middletown, Virginia

15. Owens-Thomas House, 1816-1819

William Jay

Savannah, Georgia

16. Wright Home and Studio, 1889-98

Frank Lloyd Wright

Oak Park, Illinois

17. Biltmore Estate, 1889-95

Richard Morris Hunt

Ashville, North Carolina

18. Kentuck Knob, 1953-56

Frank Lloyd Wright

Chalk Hill, Pennsylvania

19. The Schindler House, 1922

Rudolf Schindler

West Hollywood, California

20. Fallingwater from bridge, 1934-1939

Frank Lloyd Wright

Mill Run, Pennsylvania

21. The Gropius House entrance, 1938

Walter Gropius

Lincoln, Massachusetts

22. Fallingwater living room, 1934-1939

Frank Lloyd Wright

Mill Run, Pennsylvania 
23. Fallingwater hatch in living room, 1934-1939

Frank Lloyd Wright

Mill Run, Pennsylvania

24. Fallingwater fireplace in living room, 1934-1939

Frank Lloyd Wright

Mill Run, Pennsylvania

25. Fallingwater windows in Edgar Kaufmann, Sr.'s bedroom, 1934-1939

Frank Lloyd Wright

Mill Run, Pennsylvania

26. The Gropius House kitchen, 1938

Walter Gropius

Lincoln, Massachusetts

27. The Gropius House entry, 1938

Walter Gropius

Lincoln, Massachusetts

28. The Gropius House screened back porch, 1938

Walter Gropius

Lincoln, Massachusetts

29. The Gropius House office, 1938

Walter Gropius

Lincoln, Massachusetts

30. The Gropius House living room, 1938

Walter Gropius

Lincoln, Massachusetts

31. The Farnsworth House, 1951

Ludwig Mies van der Rohe

Plano, Illinois

32. The Farnsworth House entrance, 1951

Ludwig Mies van der Rohe

Plano, Illinois

33. The Farnsworth House living room, 1951

Ludwig Mies van der Rohe

Plano, Illinois 
34. The Farnsworth House kitchen, 1951

Ludwig Mies van der Rohe

Plano, Illinois

35. Fallingwater Liliane Kaufmann’s bedroom, 1934-1939

Frank Lloyd Wright

Mill Run, Pennsylvania

36. The Gropius House dining room, 1938

Walter Gropius

Lincoln, Massachusetts

37. The Farnsworth House bedroom, 1951

Ludwig Mies van der Rohe

Plano, Illinois

38. Fallingwater Edgar Kaufmann, Sr.'s bedroom, 1934-1939

Frank Lloyd Wright

Mill Run, Pennsylvania

39. Photo of the Farnsworth House flood, 2008

Ludwig Mies van der Rohe

Plano, Illinois 


\section{INTRODUCTION}

Modern architects (working from late 1800s until the first half of the Twentieth-Century) created new philosophies and a new style of architecture, no longer looking to past architecture, rejecting ornamentation, and embracing modern technology and materials into their designs. In the second half of the Twentieth-Century, the homes designed by these modern architects have become a new type of house museum. Traditionally, many house museums’ significance has been due to the social history of the site, with an emphasis on how its occupants lived in the past. With modern house museums, the significance is generally the architectural design by a famous architect. Because this new type of house museum now has the architecture as its significance, there have been changes in interpretive themes and new philosophies of preservation.

The significance of a house museum affects the interpretive and preservation plans of the site. With many traditional historic house museums, where the significance is the history, the interpretation is about a historical event or figure, or about how people of a certain time lived. ${ }^{1}$ Historic house museums typically have three to five interpretive themes which consist of the history of the site, with architecture being a sub-theme. ${ }^{2}$ Each theme has a topic that is discussed throughout the interpretative tour. Themes of a historic site can be the life of a historical figure, how the occupants lived, servitude, and more.

Because the history is so important to the traditional historic house museum, the preservation efforts focus on preserving the historic material of the structure. ${ }^{3}$ The institutions

\footnotetext{
${ }^{1}$ Interpretation at house museums is an explanation of the story of the site done through guided tours, recorded selfguided tours, wall texts, and informational placards. For modern house museums, the interpretation educates the visitor of the design concept of the structure.

${ }^{2}$ Barbara Abramoff Levy, Sandra Mackenzie Lloyd, and Susan Porter Schreiber, Great Tours! Thematic Tours and Guide Training for Historic Sites (New York: Alta Mira Press, 2001) 4.

${ }^{3}$ Preservation is defined by the National Park Service as the act or process of applying measures necessary to sustain the existing form, integrity, and materials of an historic property.
} 
running the sites want to keep the site as original to the historically significant time period as possible; therefore, keeping as much of the original material as possible. To make the house feel authentic to the period, some preservationists allow the patina to show on the historic material. For example, the arts and crafts structure, the Gamble House (by Charles and Henry Greene, 1908, in Pasadena California) (figure 1). In 2003 a major project to conserve the exterior materials (mainly different types of wood), where they did not preserve it to match its 1908 appearance, but allowed the patina continue to show. ${ }^{4}$

With modern homes becoming public museums, attitudes toward interpretation and preservation have changed. Where the significance of historic sites is the history, modern structures often focus on the architecture. Most of these sites are designed by famous architects of the modern movement, making them significant to architectural history. Some are considered architectural masterpieces. Because these houses are so important to the architectural world, their main interpretive theme is the architecture. Social history is discussed to support the architectural interpretation.

Along with the interpretation changing with modern house museums, the preservation philosophies have also transformed. Since the architecture is the main significance, part of the mission of these sites is to preserve the architect's design. Unlike historic sites where they often keep the historic material and show patina, the staff of modern house museums is typically less hesitant to remove historic material in order to preserve the original design.

Three examples of modern house museums that will foreground the changes in interpretation and preservation to be explored in this study are the Gropius House (1938 in Lincoln, Massachusetts) (figure 2), the Kaufmann House, most commonly known as

\footnotetext{
${ }^{4}$ Hadiya Strasberg, “A Philosophy of Respect Guided the Conservation of Greene \& Greene’s Gamble House,” Period Homes, http://www.gamblehouse.org/conservation/articles/periodhomes.html (accessed March 27, 2012).
} 
Fallingwater (1934-39 in Mill Run, Pennsylvania) (figure 3), and the Farnsworth House (19451951 in Plano, Illinois) (image 4). The Gropius and the Farnsworth houses are run by traditional organizations (the Gropius house by Historic New England and the Farnsworth House by the National Trust for Historic Preservation), while Fallingwater is under the trust of a organization not traditionally known for its work with house museums (the Western Pennsylvania Conservancy). A traditional organization is one that has been established and customarily works with historic properties. ${ }^{5}$ At each of these sites, designed by significant figures in modern architecture, the architectural design is interpreted, and all work to preserve the design of the homes; however, they all vary in the way they approach preservation and restoration. The Gropius House is the most traditional, the Farnsworth House is the most progressive, and Fallingwater falls between the two.

The start of historic preservation and house museums was in the 1850s, and began for political reasons. In Patricia West’s book, Domesticating History: The Political Origins of America's House museums, she discusses the political origins of historic house museums with four case studies. She discusses the beginning of historic preservation and the first American house museum at George Washington’s Mount Vernon in 1860 (1757-1799 Mount Vernon, Virginia). West describes the beginning of Mount Vernon (image 5) as a historic house museum started by Ann Pamela Cunningham and the Mount Vernon Ladies Association (MVLA) to save and preserve Washington's home during the antebellum period. The MVLA brought women into the public sphere by making house museums a task for women since they are about domesticity. Not only did the MVLA want to save Mount Vernon from deterioration, they

\footnotetext{
${ }^{5}$ The National Trust and Historic New England are both organizations that have been long established in the preservation field.
} 
wanted to "exert their moral influence on the public realm."6 They wanted to "regenerate the corrupted politics of the country by reviving, by the green shades and flowing streams of Mount Vernon, those great principles of Christian polity."7 West shows that this was not easy for Cunningham, due to trying to involve both Southern and Northern women in the effort to save the home before the American Civil War. The MVLA did not want to preserve the house to make a shrine for Washington, but a place where visitors could experience where the founding father lived among his possessions. The women wanted to recreate his domestic environment. ${ }^{8}$

West uses Thomas Jefferson’s Monticello (1769-1782 Charlottesville, Virginia) to discuss how the house museum field became professionalized, and when the federal government became involved. The project of turning Monticello (image 6) into a house museum was initially started by another woman's group in the late 1910s and early 1920s, but evolved into a men's project as the Thomas Jefferson Memorial Foundation took on developing the house into a museum in 1923. What was also new was the involvement of the federal government, due to the Democratic influence of the foundation. One of the issues they faced during negotiations for purchasing the home, was that some members thought the house should be taken by eminent domain of the government, going against Jefferson's political philosophy and ideals. However, the Levy family eventually sold the property to the foundation. The development of Monticello as a museum also established the role of professional men in house museums. Fiske Kimball is one of the first male professionals working for a house museum and changed the way many things were done. For example, he would not allow furniture or artifacts in the home unless it

\footnotetext{
${ }^{6}$ Patricia West, Domesticating History: The Political Origins of America's House (Washington D.C.: Smithsonian Books, 1999), 2-3.

${ }^{7}$ Ibid., 2-3.

${ }^{8}$ Ibid., 99.
} 
could be proven they were there when Jefferson lived, resulting in more period appropriate items and more research done on these items. ${ }^{9}$

Historic preservation is considered to have started with the Mount Vernon Ladies Association and George Washington's home; but since then, national standards and laws have been established for the practice of preservation of historic properties, including historic house museums.

Preservation standards practiced by most house museums typically come from the Secretary of the Interior's Standards for the Treatment of Historic Properties (first published online in 1992). The guidelines are set for all historic structures for preserving, rehabilitating, restoring, and reconstructing; although, the standards are based on Victorian houses. It instructs how to choose a method, and how to carry out the method chosen for each kind of historic structure. The guidelines state the differences between the four methods in hierarchal order, starting with preservation, rehabilitation, restoration, and then reconstruction. Priority is put on preservation, since it "places a high premium on the retention of all historic fabric through conservation, maintenance and repair." ${ }^{10}$ The standards and guidelines for preservation stipulate the original character, historic material, and historic features are kept to maintain the historic significance of the structure. Guidelines are listed to show the process of preservation, including choose how to the appropriate treatment (for different types of structures and materials); identify, retain, and preserve the historic material and features; stabilize or repair the historic material and features; and protect and maintain the historic material and features. Restoration is the treatment used to remove material not from the significant period, but to maintain the historic materials from the significant period. The standards for restoration are much like the ones for preservation;

\footnotetext{
${ }^{9}$ West, Domesticating History, 123.

${ }^{10}$ Secretary of the Interior's Standards for the Treatment of Historic Properties, http://www.nps.gov/hps/tps/standguide/overview/using_standguide.htm (accessed November 21, 2011).
} 
instead, it makes sure that, although it is not original, the restoration retains historical integrity and nothing that is historically unrelated is added. The guidelines go into detail in order to help identify the best treatment to use for the historic building based on the condition, and the materials used. $^{11}$

The 1993 book Historic House Museums: A Practical Handbook for Their Care, Preservation, and Management, Sherry Butcher-Younghans provides a resource for house museums to use to guide the staff on preservation, and interpretation. When discussing preservation for historic house museums, Younghans defines conservation as "the preservation and maintenance of cultural materials as well as of the house itself."12 She focuses on how museums should carry out preventative conservation through identifying problems, controlling the physical environment (including climate control and lighting), pest control, housekeeping/ cleaning, and collection handling procedures. ${ }^{13}$ Housekeeping is expanded upon by explaining how to set procedures, in order to carry on preventative conservation. A chapter of the handbook is reserved for preservation (for continual maintenance of a historic structure), rather than restoration. She refers to restoration as "recreating the original architectural elements in a building so that it closely resembles the appearance it had at some previous point in time."14 She does not cover restoration, as the book assumes the house has been restored. Younghans states that historic house museums are ethically committed to preservation standards as established by the Secretary of the Interior's Standards for the Treatment of Historic Properties. The main objective of this section is how to keep up with the inevitable deterioration through regular

\footnotetext{
${ }^{11}$ Secretary of the Interior's Standards for the Treatment of Historic Properties (accessed November 21, 2011).

${ }^{12}$ Sherry Butcher-Younghans, Historic House Museums: A Practical Handbook for Their Care, Preservation, and Management (New York: Oxford University Press, 1993), 103.

${ }^{13}$ Conservation is maintaining the material without making changes, while preservation work can include repairs to the material.

${ }^{14}$ Butcher-Younghans, Historic House Museums, 146.
} 
maintenance. ${ }^{15}$ Younghans does briefly address restoration, saying "replacements should be identical, or replacements-in-kind" and should use "similar materials, sizes, finishes, and designs" to preserve the integrity of the house. ${ }^{16}$

Historic House Museums also addresses the interpretation for house museums for the public. Younghans states "from the experience the visitor understands a number of historical realities. ${ }^{17}$ She discusses how to create an interpretive program by conducting historic research using house contents and physical research, deciding on an interpretive approach (how to present information thematically), and choosing the best interpretive technique for different types of house museums. ${ }^{18}$

Jessica Foy Donnelly’s Interpreting Historic House Museums, from 2001, is a compilation of essays all dealing with the interpretation of house museums. The author of each essay discusses a different issue within the house museum field. In the introduction, Donnelly discusses the audience, saying the interpretation must not only reflect the knowledge about the history of the site, but the knowledge of the site's audience. The effectiveness of the interpretation is based on addressing the visitor's interests, making the house mean something to them. ${ }^{19}$

Patrick H. Butler III’s essay in Donnelly’s book “Past, Present, and Future: The Place of the House Museum in the Museum Community" discusses the challenges of the present and the future, including the change in audiences and interpretation. He states that historic house museums evolve much as visitors do. He also feels society's understanding of the past is

\footnotetext{
${ }^{15}$ Butcher-Younghans, Historic House Museums, 149.

${ }^{16}$ Ibid., 164.

${ }^{17}$ Ibid., 182.

${ }^{18}$ Ibid., 182. Three types of house museums are described: the documentary historic house museum, the representative historic house museum, and the aesthetic historic house museum.

19 Jessica Foy Donnelly, Interpreting Historic House Museums (Walnut Creek, CA: AltaMira Press, 2002$), 9$.
} 
changing, and now it is no longer efficient to speak of the historical figure, but rather suggests placing the house in the context of its time. ${ }^{20}$

“Interpretation Planning: Why and How,” by Barbara Abramoff Levy, is an essay on creating effective interpretation for a house museum. She discusses the best strategy for creating an interpretive plan by learning the history of the site, understanding the audience, and so on. Levy also discusses how to create themes for the interpretation, stating "themes are essential to successful interpretation." 21 She says that the interpretive theme is the main importance to the history of the site, and should express the concerns of the visitors. She suggests that there should be three to five themes which, when woven together, make up one storyline that conveys the “important ideas, events, and features that make that site special.”22

These resources are valuable to the historic house museum field when it comes to the areas of preservation and interpretation, yet none address these issues in relation to modern house museums. Today’s modern house museums cannot simply be slipped into the same standards and guidelines for the preservation and interpretation of historic house museums. They are faced with different circumstances, stemming from their differences in significance. Modern house museums’ concern is generally the architectural design, and there are only a few references about how to deal with preserving the intent of the architectural design, while there are none for historic or modern structures.

These sites are unique not just because of the architecture, but because of the new types of materials being used and because the structures are site specific. The materials are a substantial part of modern architecture's aesthetic. These were new materials of the time that were mass-produced, which make them more accessible today compared to historic house

\footnotetext{
${ }^{20}$ Donnelly, Interpreting Historic House Museums, 63.

${ }^{21}$ Ibid., 51.

${ }^{22}$ Ibid., 51-52.
} 
museum that can include rare materials (such as different types of wood, marble, or other materials that can be hard to access). These sites are also site specific; the modern structures’ designs were designed specifically for their location, where historic structures' designs do not reference its context like modern buildings do.

The adaptation of new philosophies to the new genre of modern house museums is not commonly discussed in the field. The new philosophies reference the new ideas of interpretation and preservation for modern house museums. This is mainly due to the fact that modern house museums are so new; Fallingwater, for example, is one of the oldest that became a house museum in 1963, the Gropius House in 1985, and the Farnsworth House in 2003. A common set of new standards, mainly for preservation, for modern house museums has not been established, leaving each site to create their own standards based on those set by the Secretary of the Interior first in 1978 and last revised in 1992, which are based on Victorian houses and other structures that fit into the fifty-year rule (the site must be at least fifty years old to be considered for the National Register of Historic Places). ${ }^{23}$ Journal articles, news reports, and symposia have acknowledged this new issue, but no official standards have been set specifically for modern house museums. These articles discuss the preservation efforts, but do not address how these sites’ preservation efforts and interpretation is different from traditional historic sites. Although they bring up the topic, they do not go into detail how significant and progressive these sites are with their developing standards. A symposium held by Fallingwater staff at the Carnegie Museum of Art in Pittsburgh, Pennsylvania in 2011, "Private Domains/ Public Displays: The Modern House Interpreted,” is one of the first instances where preservation and interpretation of modern sites was specifically discussed, where professionals from nine modern house museums spoke publically about what their institutions are doing.

\footnotetext{
${ }^{23}$ Secretary of the Interior's Standards for the Treatment of Historic Properties (accessed November 21, 2011).
} 
This study explores how these particular modern house museums have adapted to the changes in interpretation and preservation in the field, and how they are developing new standards. Insight to issues currently being discussed are offered in addition to how each site is dealing with the issues, and what can be done collectively by these sites to create universal standards for modern house museums.

This study involved onsite research at the Kaufmann House/ Fallingwater, the Gropius House, and the Farnsworth House. After interning at Fallingwater, I became familiar with their interpretation and preservation methods, and continued with more research going through their archives and reviewing their interpretation and preservation manuals, along with discussing the issues with the Curator of Building and Collections. At the Gropius House, I visited the site for a standard tour, met and discussed with the project managers how they operate interpretive tours and preservation, and researched the archives dealing with preservation. At the Farnsworth House, I was able to meet with the director of the site to discuss preservation and interpretation, and take a tour to analyze the interpretation. I also attended a symposium where professionals of modern house museums discussed the interpretation and the preservation efforts at their museum.

It is clear that the new philosophies of interpretation and preservation at modern house museums is important because they represent a change in standards that are not entire compliant with the Secretary of the Interior’s Standards and Guidelines. With new standards developing, there needs to be a collective agreement on a universal set of standards as more and more modern houses are becoming museums. 


\section{CHAPTER ONE \\ A New Generation of House Museums}

Modern house museums are a distinct type within the house museums field. These houses were created differently, became museums under different circumstances, have different reasons for significance, and some operate under different institutions than the typical historic house museums; therefore, leading to new operational philosophies. This chapter identifies these differences, and how they affect the sites.

The three modern house museums being explored here use the standards set by the Secretary of the Interior, but are more lenient about not preserving historic material. Modern sites are more concerned with the architectural design by the significant architect than saving the historic material. ${ }^{24}$ This is because the mission of modern house is to educate the public on the modern movement in architectural history, and most modern architects (such as Mies van der Rohe, Walter Gropius, Le Corbusier, Frank Lloyd Wright, Rudolph Schindler, etc.) were concerned with the use of modern materials, such as steel and glass, using them to create a smooth, sleek, unadorned, aesthetic. These architects wanted to stop looking to the past; therefore, they would not want their designs to look like a structure from the past.

Modern architecture started to develop in the mid 1800s during the Industrial Revolution. Because of the revolution, there were new and better materials (such as steel and larger plate glass) available for building structures. Originally architects were using the new materials, such as steel, as the inner skeleton of the structure (for example the Paris Opera House by Charles Garnier built in 1857-1874 in Paris, France) (image 7) but kept the traditional and classical look

\footnotetext{
${ }^{24}$ The historic material, in this case, is the building material (such as glass, siding, flooring, stonework, etc.).
} 
being taught at the Ecole des Beaux Arts. ${ }^{25}$ But architects were thinking about new ways to use the new materials, and began using them as part of the aesthetic for the building. For example, Joseph Paxton's Chrystal Palace for the London Exhibition of 1851 displayed the industrial innovations by using a metal armature- no longer making the walls load bearing- and allowing for more use of glass for the walls and roof (image 8). Gustave Eiffel took this use of material farther and used metal as part of his aesthetic for the Eiffel Tower (1899 in Paris, France) (image 9). ${ }^{26}$

These structures started making architects think about a new aesthetic. Like with Louis Sullivan's (1856-1924) buildings in Chicago, Illinois, where due to new technologies, structures were able to be built taller. He created a new aesthetic by finishing off buildings in stone and making a nod to the past without being a revivalist building, and by using roman arches and breaking the tall building into three parts referencing the classical order of the classical column. ${ }^{27}$ Frank Lloyd Wright (1867-1959) started his career under Louis Sullivan, learning the new aesthetic from him. He took this aesthetic and designed buildings that responded to their context, starting off the early part of his career by creating the Prairie Style house where the building responds to the flat land of the mid-west. Having his buildings respond to their natural context began his theory of organic architecture, where the site dictates the aesthetic. ${ }^{28}$ He felt that organic architecture should both be "visually and environmentally compatible, closely integrated with the site," and reflect the concern with the process of nature and the forms they produce. ${ }^{29}$

\footnotetext{
${ }^{25}$ The Ecole de Beaux Arts is an art academy in Paris, France where the traditional system of training in art and architecture was taught based on traditional arts.

${ }^{26}$ Gerd Hatje, Encyclopedia of Modern Architecture (London: Thames and Hudson, 1963).

${ }^{27}$ Louis H Sullivan, “The Tall Office Building Artistically Considered,” Lippincott's Magazine (March 1896).

${ }^{28}$ Hatje, Encyclopedia of Modern Architecture.

${ }^{29}$ John Flemming, Hugh Honour, and Nikolaus Pevsner, The Penguin Dictionary of Architecture and Landscape Architecture (London: Penguin Books, 1999), 413.
} 
In Europe, architects were also changing their aesthetic due to the expansion of industry. The Deütcher Werkbünd, founded 1907) was a group of architects who produced new progressive architecture to take advantage of mass production and the change in times. They also wanted to produce well-designed functional buildings. Walter Gropius (1883-1969) was part of this group, and helped create the factory aesthetic (such as the Fangus Shoe Factory in Alfeld, Germany, 1911-1913) designing for a new kind of building where German architects were thinking about the functionality of a factory and how to design an aesthetically pleasing building. Walter Gropius was also the founder of the Bauhaus School originally in Dessau Germany in 1919 (image 10) known for a more progressive way to teach art and architecture, it had a profound influence on the way art and architecture are taught to this day. One of the main purposes of the Bauhaus was to unite art and architecture, which he felt were separate for far too long and the distinction between the two should not be separated. One of his Bauhaus philosophies was that design should be a collective effort and promoted team-work in the creation of building structures and furniture. He also taught architecture in relation to industrial production, promoting the increased use of machinery in the production of well-designed objects. $^{30}$

The machine aesthetic spread among other modern architects of the first half of the $20^{\text {th }}$ century, including Le Corbusier (1887-1965) and Ludwig Mies van der Rohe (1886-1969), who were part of the architectural style that came to be called the International Style. ${ }^{31}$ The architects of this time wanted to create a unifying architectural style after the devastation of World War I. They embraced the machine aesthetic; for example, Le Corbusier was famous for saying the

\footnotetext{
${ }^{30}$ Hatje, Encyclopedia of Modern Architecture, 43-44.

${ }^{31}$ The International Style name was coined by Philip Johnson and Henry-Russell Hitchcock when they curated an exhibit about modern architecture at the Museum of Modern Art, and wrote "The International Style: Architecture Since 1922", in 1932.
} 
house is "a machine for living in.” The style included architectural elements such as white geometric forms, no applied ornamentation, glazing (the glass curtain wall), flat roofs, and a weightless and transparent affect (through the use of glazing and raising the building on steel pilasters). Mies van der Rohe followed this aesthetic, most notably in the Seagram Building (1958, New York City, New York). With the Seagram Building (image 1), he used solid geometrical forms with the use of the glass curtain wall, and the use of steel supports to raise the building off of the ground. There was no applied ornamentation in his designs, but he used Ibeams or pilotis for support and aesthetic reasons (creating a grid, which is evident in most of his designs).

The modern architectural movement dissipated in the second half of the $20^{\text {th }}$ century when the post-modern architects rejected the uniform and unsymbolic designs of the moderns. They felt modern architecture had lost relevancy to the current society, and started using applied ornamentation and symbolic forms in their designs. Robert Venturi’s (1925) designs are examples where he uses symbolic architectural elements, such as the Vanna Venturi House (1964 in Philadelphia, Pennsylvania) (image 12) where he prominently points out the chimney and uses the Roman arch.

Since the fresh and modern look of these buildings is so important, modern house museums want to keep with the architect's desired aesthetic and will restore the material, or even replace worn material all together, where historic houses will allow patina to show because it is the original material of the significant time period emphasized at the house. Keeping the original material is desired at modern house museums, but it is not as important as it would be in a historic house. Modern house museums go by many of the standards set by the Secretary of the 
Interior, but the standards do not specifically mention buildings with modern designs in order to provide guidance for the best treatment.

\section{Background of the Gropius House, Fallingwater, and the Farnsworth House, and How They}

\section{Became Museums}

The Gropius House (1938 Lincoln, Massachusetts) (image 2) was the home of Walter Gropius (1883-1969), leading International Style architect and a founder of the Bauhaus, that he built for himself and his family. Gropius moved to the United States after leaving Nazi Germany in 1934 and England in 1937. He and his family settled down in New England after Gropius became the chairman of the Harvard Graduate School of Design in Architecture in $1937 .{ }^{32}$ Gropius and his wife, Ise, both lived at the home until their deaths; although, Ise donated the house to the Society for the Preservation of New England Antiquities (now known as Historic New England) in 1979, she lived there the rest of her life. Two years after her death, the Gropius House opened to the public as an historic house museum, and it has been operating under Historic New England ever since. ${ }^{33}$ The Gropius House is important to the architectural world because it is an example of Gropius' Bauhaus philosophy implemented in his own home in America. As discussed later in this study, the design was a collaborative effort of the entire family, and it shows the love of new mass produced materials (such as steel, cork, and other modern materials) much like in his design for the Bauhaus building (1925-1926 in Dessau, Germany) (image 10).

The Kaufmann House (1934-1939 Mill Run, Pennsylvania) (image 3) was designed by American architect Frank Lloyd Wright (1867-1959) for a wealthy Pittsburgh, Pennsylvania

\footnotetext{
${ }^{32}$ Historic New England, http://www.historicnewengland.org/historic-properties/homes/Gropius\%20House/gropiushouse-history\#1983-present-becoming-a (accessed November 21, 2011).

${ }^{33}$ Ibid.
} 
family after the son, Edgar Kaufmann, Jr., suggested to his father, Edgar Kaufmann, Sr., to commission Wright. They asked Wright to build the home by their favorite spot on their vacation property in nearby Bear Run, Pennsylvania, and Wright surprised them by building the house cantilevered over the waterfall. Wright named his design "Fallingwater." The house stayed in the possession of the Kaufmann family after the deaths of Edgar Kaufmann, Sr. and his wife Liliane, until Edgar Kaufmann, Jr. donated the house and surrounding 1,600 acres to the Western Pennsylvania Conservancy in 1963. A year later, the house was opened to the public as a house museum. Although it was no longer Kaufmann's vacation home, he still had some control over the site and how it was interpreted and what was collected for it until his death in 1989. ${ }^{34}$ Fallingwater is believed by many architectural historians to be the most significant piece of modern architecture in America. Also it exemplifies Wright's theory of organic architecture, along with his earlier home and studio Taliesin East (b.1911 in Hillside, Wisconsin) and immediately following West (1938-1941 in Scottsdale, Arizona).

The Farnsworth House (1945-51 in Plano, Illinois) (image 4) was designed by International Style architect, Ludwig Mies van der Rohe (1886-1968), for Dr. Edith Farnsworth, an accomplished nephrologist of Chicago, as a weekend home after the two met and developed a close friendship. In 1968, Dr. Farnsworth put the house up for sale and it was purchased by Lord Peter Palumbo, a collector of contemporary and modern art and architecture who took possession of it in 1971. While in ownership of the house, Lord Palumbo enlisted Mies' grandson, architect Dirk Lohan, to help redecorate the interiors with Mies-designed furniture he thought Mies would have used if given the chance by Dr. Farnsworth. ${ }^{35}$ In 1997, Landmarks Illinois and the National Trust purchased the home and saved it from possible demolition after Lord Palumbo put the

\footnotetext{
${ }^{34}$ Linda Waggoner, Fallingwater (New York: Rizzoli, 2011), 12.

${ }^{35}$ Franz Schulz, The Farnsworth House (Lohan Associates), 22-28.
} 
house up for sale. The furnishings added by Palumbo and Lohan remained in the house. The house has been open to the public since then, and as of 2003, has been operated by the National Trust. $^{36}$ The Farnsworth House is a distinctive design by Mies, with the of floor to ceiling glass making the house transparent, the use of I-beam supports, the grid pattern, and use of volume of mass. This is similar to his design for the Barcelona Pavilion for the 1929 International Exposition in Barcelona, Spain (image 13).

\section{Background of the Operating Institutions}

Historic New England is one of the oldest historic preservation organizations. It was founded by William Sumner Appleton who originally named it the Society for the Preservation of New England Antiquities (SPNEA). After he learned about the significant alteration of a structure where an important American Revolution event happened, Appleton took the legal steps to found SPNEA in 1909. His legacy "brought a scientific method to his approach and defined procedures that are largely followed to this day. He came to see a building as an evolving organism, whose changes over time preserved the historic record of many eras. This enabled him to resist the temptation to restore a building to a particular period to make it easier for a layperson to understand., 37

Historic New England's mission is to protect, preserve, and present New England's

heritage and cultural history to the public. The mission statement reads:

Historic New England is a museum of cultural history that collects and preserves buildings, landscapes, and objects dating from the seventeenth century to the present and uses them to keep history alive and to help people develop a deeper understanding and enjoyment of New England life and appreciation for its preservation. ${ }^{38}$

\footnotetext{
${ }^{36}$ Whitney French, Conversation with author, Plano, Illinois, August 2, 2011.

${ }^{37}$ Historic New England's “About Us,” http://www.historicnewengland.org/about-us (accessed March 4, 2011).

${ }^{38}$ Ibid.
} 
The operation for the Gropius House is also included under this mission statement, along with other historic properties. One of the reasons the Gropius House is important and falls under the mission of Historic New England is because the design combines traditional architectural elements of New England with the modern principles of the Bauhaus. ${ }^{39}$ Operating under Historic New England is reflected in the care of the Gropius House; although, the modern house museum is being treated uniquely since it is their only modern style "historic house museum." Because the Gropius House is a modern house museum operated by an organization among historic house museums, it makes the situation unique with peculiar context.

The Farnsworth House is also under the care of a traditional and longstanding organization for historic preservation, the National Trust for Historic Preservation. In 1947, the National Council for Historic Sites and Buildings began efforts to form a National Trust in the United States, and became the National Trust for Historic Preservation in 1949 when President Harry Truman signed legislation for it. In 2003, the National Trust helped save the Farnsworth House by purchasing the site, and opened it to the public a year later. ${ }^{40}$

The National Trust states that they provide "leadership, education, advocacy, and resources to save America's diverse historic places and revitalize our communities.”41 The organization strives to save structures at risk of deterioration or destruction in order to save America's history. The Farnsworth House falls into their mission because the structure (once in danger of being relocated) is important to the history of the modern architecture movement in America. Because of their “diverse historic properties,” they are faced with unique cases in preservation and have dealt with individual needs, including the Farnsworth House.

\footnotetext{
${ }^{39}$ Historic New England's “About Us.”

${ }^{40}$ National Trust for Historic Preservation “About Us.” http://www.preservationnation.org/about-us/ (accessed March 2, 2012).

${ }^{41}$ Ibid.
} 
The Western Pennsylvania Conservancy (WPC) does not typically deal with historic preservation. They are an organization that works to conserve the natural elements of Western Pennsylvania. Their mission statement reads:

The Western Pennsylvania Conservancy protects and restores exceptional places to provide our region with clean waters and healthy forests, wildlife and natural areas for the benefit of present and future generations. The Conservancy creates green spaces and gardens, contributing to the vitality of our cities and towns, and preserves Fallingwater, a symbol of people living in harmony with nature. ${ }^{42}$

Fallingwater is the only house under the care of the Western Pennsylvania Conservancy (WPC), making it a unique case in the preservation and house museum field. Edgar Kaufmann, Jr., felt the conservancy was a good fit because of Wright's organic design philosophy demonstrated at Fallingwater with its connection to nature, and explained this was the reason for his decision to donate to the Western Pennsylvania Conservancy, rather than to a traditional preservation agency.

Edgar Kaufmann, Jr. did not want to donate his family’s weekend home to an institutions such as the National Trust or another traditional institution because he was worried that Fallingwater would turn into another “dusty” historic house museum. Instead he donated it to the Western Pennsylvania Conservancy, and entrusted them to allow the house to transform over time by allowing changes to happen while maintaining Wright's design. Wright designed the home to have the Kaufmanns' living in harmony with nature, which is never a constant and evolves over time. Edgar Kaufmann, Jr. wanted the house, like the landscape inspiring the design, to evolve over time as well. For example, Edgar Kaufmann, Jr. wanted objects in the collection to move and change.

\footnotetext{
${ }^{42}$ Western Pennsylvania Conservancy “About Us,” http://www.paconserve.org/2/about (accessed March 2, 2012).
} 
Part of the mission of the Western Pennsylvania Conservancy’s operation of Fallingwater is to preserve the home and its history as well as applying Edgar Kaufmann, Jr.'s philosophy of maintaining the house's union with its surrounding nature. The mission statement says part of its purpose is "to maintain in Fallingwater its character as a weekend home of the period it was occupied by its owners” and “to preserve its original furnishings, art and household objects.” ${ }^{43}$ In doing so, it is exhibited as naturally as possible, making the house and its interiors seem as if it is living, domestic home while it still functions as a public space. ${ }^{44}$ Having the house's contents alter over time helps the museum exhibit the home in a natural way, keeping the character of the family using it as a weekend home. The spaces being transformed makes the house seem like it is being lived in by the Kaufmanns, who changed the spaces throughout their time there. In accordance with Edgar Kaufmann Jr.'s wishes, the Western Pennsylvania Conservancy makes it part of their mission to show the house's evolution instead of keeping it frozen in time by never making any changes within the house. The Conservancy wants to represent nature in the house, as well as maintain the character of the house as a weekend retreat of the Kaufmann family. They achieve their mission showing the house changing over time, by moving objects around, changing out objects, and when Edgar Kaufmann, Jr. was there, adding pieces to the collection.

\section{The Differences between Modern House Museums and Traditional Historic House Museums}

There are many ways in which modern house museums differ from the traditional historic house museums. They have different ways in which they are significant; traditional house museums are significant because of the history of the site, while the modern house museums are significant because they are examples of points in the modern architecture movement and

\footnotetext{
${ }^{43}$ Western Pennsylvania Conservancy's mission statement, http://www.fallingwater.org/64/mission (accessed March 22, 2012).

${ }^{44}$ Ibid.
} 
designed by renowned architects. These sites also come across new issues and administrative circumstances. They are used for different purposes compared to historic house museums, have different circumstances with ownership, and have influence from people who had a role in the site as a museum after living during its time of significance. Also many of these sites attract a different audience than the traditional house museum.

One of the differences that stands out is the significance of the house museums. Traditional historic house museums' significance is a historical figure who lived there, a historical event that happened there, or it represents a specific time period. These sites usually tell a story through their interpretation.

An example of a historic house museum where the significance is a historical figure is a president’s home. Monticello (1769-1782, Charlottesville, Virginia) (image 6) is a historic house museum that's significance is the man that lived there, Thomas Jefferson (1743-1862). The reason why it is an important home is because the third president of the United States built the home and lived there throughout his adult life; although, it is also significant because of its architectural qualities. The story being told is about Jefferson's everyday life there and the significance of his presidency. ${ }^{45}$

Other historic house museums have significance due to a historic event that happened on the site. One example of this is Belle Grove Plantation (1797 near Middletown, Virginia) (image 14). Here the history of the occupants and the architecture of the house are part of its significance, but another major part is the Civil War battle of Cedar Creek that happened on the property on October 19, 1864. During the battle, the house served as a headquarters for Union General Phillip Sheridan. Today Belle Grove and Cedar Creek are in partnership under the

\footnotetext{
${ }^{45}$ Thomas Jefferson’s Monticello Tour, Charlottesville, Virginia, October 2010.
} 
National Trust for Historic Preservation as Cedar Creek and Belle Grove National Historical Park. $^{46}$

Other house museums represent a significant time period in history, which can also include open air museums with multiple houses to tour. For example, Colonial Williamsburg is an open air museum that represents early America during colonial and Revolutionary times. Its interpretation focuses on how people lived at the time, telling the history of the people that lived there.

There are historic house museums that are significant for the architecture and the architect, and therefore interpret the architecture and its significance. An example is the OwensThomas House Museum (1816-1819 in Savannah, Georgia) (image 15), an English Regency style house designed by William Jay, one of the first professionally trained architects in America, originally for Richard Richards. The architecture is one of the main interpretive themes; although, there is a balance between the social history and the architectural history. Paulette Thompson, the Lead Interpreter, says the guide staff discusses a little bit of everything on their tours: the social history; including the family, servants, and Marquis de Lafayette's stay at the house; and the architecture; including the architectural elements, Jay’s designs, and the mechanics (such as the plumbing system). Thompson states that it is important to them that the entire story of the site is told to please all visitors. ${ }^{47}$

Historic house museums' significance is most often the historical person, event, or time period it represents, while the significance of modern house museums is usually the architecture. These sites become museums because they exemplify the modern architectural movement through the structural design. Usually these sites are significant because of the notable architect

\footnotetext{
${ }^{46}$ Belle Grove Plantation “About Us,” http://www.bellegrove.org/index.php?/about (accessed March 11, 2012).

${ }^{47}$ Paulette Thompson, telephone conversation with author, March 20, 2012.
} 
that designed the structure. And many of the houses are considered architectural masterpieces, such as Wright's Fallingwater.

Like traditional house museums, modern house museums demonstrate the history of a certain time period; although, they are exemplifying a certain time in architectural history. For example, Frank Lloyd Wright's Home and Studio in Oak Park, Illinois (1889-98) (image 16) is not only a house museum for a significant person, but it is also an example of architecture early in the modern movement, when Wright was first starting his professional career as an architect working for Louis Sullivan. ${ }^{48}$ Modern house museums exemplify a time in the architect's career as well. Fallingwater is an example of Wright's work in the middle of his long career. The house also is the example of organic architecture; a philosophy that defined Wright's mature approach to architecture during the second half of his career. ${ }^{49}$ The Farnsworth House, completed by Mies van der Rohe in 1951, is an example of a modern house built toward the end of the modern movement.

The Gropius House is different from other modern house museums like the Frank Lloyd Wright Home and Studio in Oak Park, Illinois. Both are not only examples of points in the modern architecture movement and of a significant modern architect, but they are instances of a home for a significant figure in modern architecture. Although the house tells the story of the person and family that lived in the house, its a modern architect's private home. The design and

\footnotetext{
${ }^{48}$ Frank Lloyd Wright (1867-1959) began his career under Louis Sullivan, learning the new aesthetic from him. He took this aesthetic and designed buildings that responded to its context, starting off the early part of his career creating the Prairie Style house where the building responds to the flat land of the mid-west. Modern architecture in American started with Sullivan in Chicago, Illinois where building were being able to build taller buildings creating a new aesthetic by finishing off buildings in stone and making a nod to the past without being a revivalist building, using roman arches and breaking the tall building into three part referencing the classical order of the classical column.

${ }^{49}$ Wright's theory of organic architecture is based on a building's response to its natural context, where the site dictates the aesthetic. He felt that organic architecture should both be visually and environmentally compatible, closely integrated with the site, and reflect the concern with nature's processes and forms.
} 
the appearance of the home are important to the architect, so the architecture of the home is the main significance of the site.

Modern house museums have many new philosophies that are not implemented at most historic house museums. For instance, modern house museums work to make sure the house does not seem stagnant and want the house to seem as natural of a home as possible.

Fallingwater is a leading example of this new philosophy. Edgar Kaufmann, Jr. wanted his family's weekend home to be a public museum, but did not want it to turn into a historic museum that remained stagnant. The staff today makes sure Kaufmann’s vision remains by displaying the house as naturally as possible. The changes over time also show how the home evolves over time like nature does, tying to Wright’s organic theory. Edgar Kaufmann, Jr.'s philosophy was that the house represents man living harmoniously with nature, and in order for Fallingwater to continue to be harmonious with nature it has to evolve over time as nature does.

In April of 1985, Edgar Kaufmann, Jr. gave a tour of his former family weekend retreat. In the tour, he described the renewal of nature, and how this affects visitors to the forested area. ${ }^{50}$ In his introduction, he explains the reason for his family's use of the area. He stated they were "entirely accustomed to the idea that people who lived and worked in the city needed to get away, whenever they could, to nature, to the country, to recharge themselves."51 Even before the house was built, the family used the property to get away from the stresses of work and city life and recharge themselves through their experience of being one with nature. They even used their property along Bear Run for employees of the Kaufmann Department Store to recharge themselves. Edgar Kaufmann, Jr. described the matter of renewal with people, as well as with nature. "The third thing that reinforces all of this attitude, which I think is a big part of it

\footnotetext{
${ }^{50}$ Edgar Kaufmann., Jr., “Edgar Kaufmann Jr. Tour of Fallingwater: April 1985,” Western Pennsylvania Conservancy Archives, Fallingwater Mill Run, Pennsylvania.

${ }^{51}$ Ibid., 1.
} 
although it's a rather inconspicuous part of it, is the fact that the nature here in this area, is also a matter of renewal, and a matter of recreation, recreation. This is a place where renewal was not only a matter of people, but a matter of the woods and the streams, themselves.”52

When Wright designed the house with this in mind, he intended the family to live in harmony with the surrounding landscape, tying into his organic architectural theory where the architecture should respond to the natural context. Wright and the Kaufmanns both "shared a belief that human beings are refreshed and- not to put too much weight on the word- bettered if they spent some time in nature, responding to nature, trying to bring out whatever lies within them which is in harmony with simple, natural selection.”53 Edgar Kaufmann, Jr. also once stated in reference to the house: "It is a powerful statement of the fertile relationships between mankind and the natural environment." ${ }^{54}$ Wright's intention for Fallingwater was to be a catalyst for human's relationship with nature. Wright said of the building being one with nature and that relationship with humans: "I think you can hear the waterfall when you look at the design. At least it is there and he lives intimately with the thing he loves." 55 To be the method for the occupants to go through renewal like the Kaufmanns intended when they had retreats in nature, the house must act like nature and be in constant evolution or revival.

In his 1985 tour, Edgar Kaufmann, Jr. also explained how the woods of their property had repaired itself through the years. He said:

Nature grew up here. So what we're seeing here is not the 'forest primeval,' but a wonderful piece of very beautiful terrain that has its own vitality, that has recovered from its own problems in its own way. So that when other people, or my parents as it happened, came here to this, the whole idea of the relationship

\footnotetext{
${ }^{52}$ Kaufmann., Jr., “Edgar Kaufmann Jr. Tour of Fallingwater: April 1985,” 1.

${ }^{53}$ Edgar Kaufmann., Jr., “Edited Text of Fallingwater Discussion: 31 May 1974,” Western Pennsylvania Conservancy Archives, Fallingwater Mill Run, Pennsylvania., 2.

${ }^{54}$ Edgar Kaufmann., Jr., "Remarks on Fallingwater as Administered by the Western Pennsylvania Conservancy," Western Pennsylvania Conservancy Archives, Fallingwater Mill Run, Pennsylvania, 1.

${ }^{55}$ Bruno Zevi, Towards an Organic Architecture (London: Faber \& Faber Limited, 1950), 111.
} 
between people and nature was already thoroughly, thoroughly established... It was just part of existence ${ }^{56}$

The area had been affected by human interaction before the house was built, and even before the Kaufmanns owned the property. The land was used for lumbering, and there was a stone quarry on the property. Edgar Kaufmann, Jr. was describing how nature recovered from this in its own way. This is another reason for demonstrating change over time in Fallingwater, because like nature, the house goes through repair. From the time the Kaufmanns moved into the house to today, the house has gone through many changes due to repairs (such as cracks in concrete, broken rocks in the floor, and deflecting terraces), like any home would. Making changes through repairs enforces the mission to make Fallingwater a living house museum.

Edgar Kaufmann, Jr. also emphasized how the house, like nature is a living organism: "The house is a breathing organism, and it has to be given a chance to breathe, it has to be given a chance to accept what little leak there is, and it's still going to give trouble, but not nearly as much trouble, if we really focus on it." ${ }^{\text {57 }}$ This can be interpreted that if you keep the house stagnant and stuck in one moment in time, it keeps the house from "living." Or in other words, this keeps it from seeming like a living house museum and an inhabitable place. Also, this statement reflects what Edgar Kaufmann Jr. said about the repair of the house. Like nature, the house accepts and evolves with the changes with which it is faced.

Along with the house being an organism of renewal and showing the evolution over time, Fallingwater also serves as a frame for the changing and surrounding landscape. Edgar Kaufmann, Jr. said:

Wright has responded to a relatively featureless plant growth, masses of rhododendron, repeated verticals of tree trunks, no particular accents nor openings

\footnotetext{
${ }^{56}$ Edgar Kaufmann., Jr., “Edgar Kaufmann Jr. Tour of Fallingwater: April 1985,” 1.

${ }^{57}$ Ibid., 13.
} 
and closings of space. Generally, just a mass of green; or, in the winter, of white; or, in the fall, of warm colors; but an undifferentiated expanse. He has given a pattern and rhythm by framing it in metal, in equal segments, by contrasting it to the horizontals of the floor and ceiling... he merged the architecture with the outdoors. $^{58}$

Wright used his design, especially the windows, to frame the ever-changing outside scenery through the seasons and the years. The house, in order to frame the landscape aesthetically and continue to merge with the landscape, changes along with nature.

Because Edgar Kaufmann, Jr. wanted Fallingwater to evolve over time after it had made the transition from private residence to a public museum, he was selective of the organization to which he donated the house and property. He did not want his family's vacation home to turn into another traditional historic house museum or institution: "Fallingwater is not an institution, it is a humane experience, gauged to the whole gamut of public attendance so that mere curiosity and professional investigation, and all intermediate stages of interest, can find their ways unimpeded by any preconceived dogmas or standards."59 Donating the house to an institution like the National Trust of Historic Preservation would not fit with Edgar Kaufmann, Jr.'s wishes. That is why he entrusted it to the Western Pennsylvania Conservancy. He said it is important for the "inevitable changes brought by time" to be embraced by the Conservancy. ${ }^{60}$ He felt the real mission of Fallingwater is not predetermined, but should evolve "out of the excellence of art and the matching excellence of responsible caretaking," and the Conservancy is capable of the responsible caretaking. ${ }^{61}$ This philosophy of showing changes over time and evolving like nature around the house that Edgar Kaufmann, Jr. emphasized is at odds with that of traditional

\footnotetext{
${ }^{58}$ Edgar Kaufmann, Jr., “Edited Text of Fallingwater Discussion: 31 May 1974,” 14.

${ }^{59}$ Edgar Kaufmann., Jr., "Remarks on Fallingwater as Administered by the Western Pennsylvania Conservancy,” 2.

${ }^{60}$ Ibid., 2.

${ }^{61}$ Ibid., 2.
} 
historic house museums, which many strive to keep the house as it was during the significant time period.

The change over time is shown through the changes made to the interiors over the years by objects and furniture being replaced or moved, and by repairs made to the structure. Also, it is represented by discussing how Frank Lloyd Wright designed the house to live in harmony with nature, which evolves over time. This key concept of living in harmony with nature is emphasized throughout the house when the tour guides discuss elements, such as the horizontal windows spanning the entire width of the wall in the living room. ${ }^{62}$ It is introduced at the beginning of the tour, when the tour guide greets a group at the bridge over Bear Run leading to the house. This is where the general history of the Kaufmanns and Fallingwater, and Wright's design, "which resulted in the creation of a masterpiece of modern architecture which symbolizes living in harmony with nature.”63 The interpretive guide book given to tour guides does mention the preservation philosophy, held by the Western Pennsylvania Conservancy, which will maintain the structural integrity, but allows that changes can be made as long as there are no revisions to the original design by Wright. ${ }^{64}$

Today the curatorial staff of Fallingwater does their part in presenting the house as naturally as possible. The Fallingwater Preservation Guidelines state under the preservation philosophy that "the interiors should be presented as home-like as possible and people should be able to experience the house by walking freely within every room without typical museum devices barriers, ropes, vitrines, labels, etc.”65 Unlike historic house museums where rooms are roped off so the visitors cannot move through and interact with the space, Fallingwater is

\footnotetext{
${ }^{62}$ Fallingwater Interpretive Manual, revised 2009, n.p.

${ }^{63}$ Ibid., section: Day 2, n.p.

${ }^{64}$ Ibid., History section: structure history, n.p.

${ }^{65}$ Justin Gunther, Fallingwater Preservation Guidelines, 4.
} 
presented without these hindrances to make it feel as though you are visiting the Kaufmann's vacation home instead of a museum.

Edgar Kaufmann, Jr.’s influence on Fallingwater’s transformation into a house museum, as discussed above, is another way modern house museums are unique. Many historic house museums become public years after the significant occupant has vacated the property. At modern house museums, as seen in two of the case studies, the governing organization takes control when the property is donated by the original owner to them. And if this is not the case, the property has not gone through many owners.

The Gropius house was donated to Historic New England (then known as Society for the Preservation of New England Antiquities or SPNEA) in 1979 by Gropius’s wife Ise, and officially taken over in 1983 following her death. ${ }^{66}$ Their daughter, Ati Gropius Johansen, has had much influence since then. She had an influence on the furnishings plan, has given oral histories, written about her father's design for the house, and to this day visits the house regularly to give her input on how things should look (as discussed later in this thesis).

The Farnsworth House had a curatorial influence similar to Fallingwater and the Gropius House. When Dr. Farnsworth sold the house in 1971 to Lord Peter Palumbo, ${ }^{67}$ Dr. Farnsworth took her furniture, which was not designed by Mies van der Rohe nor modern in design, leaving Lord Palumbo to furnish the house himself. ${ }^{68}$ Palumbo wanted to decorate the home in furniture designed by Mies van der Rohe. To do this, he hired Mies van der Rohe’s grandson Dirk Lohan, who is also an architect, to design the interior as Mies would have if he had the opportunity. He used Mies’ furniture, as well as his philosophy on simplicity, less is more. When Lord Palumbo

\footnotetext{
${ }^{66}$ Gropius House website, http://www.historicnewengland.org/historic-properties/homes/Gropius\%20House (accessed March 11, 2012).

${ }^{67}$ Lord Palumbo is a real estate developer from England and a collector of modern art and architecture.

${ }^{68}$ Dr. Farnsworth originally had Scandinavian furniture and later replaced it with a mixture of Chippendale and modern furniture.
} 
auctioned the house to Landmarks Illinois and The National Trust in 1997, he included the furniture collection with the home. The Farnsworth House staff and The National Trust still consult with Palumbo and Lohan on curatorial issues that arise. ${ }^{69}$

Another difference modern house museums have versus traditional historic house museums is the audience. Fallingwater is an exception in that it has a wide variety of visitors, and a large attendance yearly. But modern architecture sites such as the Gropius House and the Farnsworth House have a more specific audience than Fallingwater and other historic house museums. Current executive Director of the Farnsworth House, Whitney French, states that their audience is mostly people who are educated in architectural history, specifically modern architecture. These visitors range from architects, designers, artists, art and architectural historians, etc. This type of audience is not as concerned with antiquities and history, they are more concerned with getting to experience the site and spaces, and to be able to see the architecture in person. The content of the tours require some knowledge of the modern architectural movement; but for those who are not knowledgeable, the goal at the Farnsworth House is to get them to understand and experience the structure while helping them understand the significance of the design within the modern movement. French breaks down their audience into thirds. One third of the visitors are international, interested in Mies van der Rohe (from Germany) and the International Style. Another third are people from Illinois, most of whom bring friends or family that are visiting. The final third are the professional designers, architects, and historians. $^{70}$

What also sets some of these modern house museums apart is that the owners continue to collect and introduce pieces of art into the house. Some house museums are not owned by a

\footnotetext{
${ }^{69}$ Whitney French, conversation with author, Plano, Illinois, August 2, 2011.

${ }^{70}$ Ibid.
} 
nonprofit organization, but rather by a private owner. One well-known example of this is the Biltmore Estate (1889-95 in Ashville, North Carolina) (image 17), where William Cecil (grandson of George Vanderbilt) runs the house museum for profit in order to keep up with preservation work. ${ }^{71}$ Kentuck Knob (1953-56 in Chalk Hill, Pennsylvania) (image 18), another Frank Lloyd Wright house near Fallingwater, is also privately owned by Lord Peter Palumbo. Since the house museum is under his ownership, he is able to acquire art as he pleases, and introduce new pieces into the house. For Palumbo, this is usually contemporary art work. ${ }^{72}$ When Edgar Kaufmann, Jr. was still alive and after he left Fallingwater to the care of the Western Pennsylvania Conservancy, he would collect art for the house regularly. As at Kentuck Knob, these were usually artworks such as paintings, sculptures, and pottery. When Kaufmann died in 1989, pieces for the house were no longer being acquired, leaving only the donated pieces from Kaufmann. ${ }^{73}$

Modern house museums are no longer being used as typical house museums with interpretive tours. Some are becoming art museums that still teach about the modern architecture of the building. An example of this is the Schindler House (1922) in West Hollywood, California (image 19). The house was built by Rudolf Schindler for himself, and years after his death, in 1977, the Friends of Schindler House group acquired the property to preserve it. In August of 1994, the MAK center (the Austrian Museum of Applied Arts) made an agreement with the friends group to create the MAK Center for Art and Architecture at the Schindler House. The MAK uses it for programs for art and architecture, mainly as gallery and studio

\footnotetext{
${ }^{71}$ Howard E. Covington Jr., Lady on the Hill (Hoboken: John Wiley and Sons, Inc., 2006).

${ }^{72}$ Lisa Berg, conversation with author, Chalk Hill, Pennsylvania, March 2011.

73 Justin Gunther, conversation with author, Mill Run, Pennsylvania, March 2011.
} 
spaces for resident artists to exhibit their work. Their goal is to use the programs and art to teach Schindler's theories on architecture, and to keep the house alive. ${ }^{74}$

With the creation of modern house museums, new and unique differences have developed in the house museum field. Because the architecture is designed by a famous architect of the modern movement, the house's significance is different from past house museums, making their treatment in many aspects different. Some modern house museums are under operation of organizations not typical for historic preservation, they are not used as typical house museums, and they are not interpreted or preserved as traditional historic house museums.

\footnotetext{
${ }^{74}$ Kimberli Meyer, “The MAK Center at the Schindler House: Taking Cues from a Modern Experimentalist” (presentation at Private Domains, Public Displays: The Modern House Museum Interpreted symposium, Pittsburgh, PA, April 5, 2011).
} 


\section{Chapter 2}

\section{The Interpretation of Architecture at Modern House Museums}

Historic house museums interpret the social history of the house through the method the museum adopts, whether with tours given by guides, audio tours, interpreted labels, and wall text. Most of these museums discuss the architecture of the house; although, the focus of the interpretation is different for each house museum. With traditional historic house museums, the main theme of the interpretation is generally about the social history of either a significant event or person, with a supporting theme containing the architectural history. The architectural history of the building usually is a brief overview of the style, its significance, and by whom (for example: Thomas Jefferson's Monticello (image 6) tours briefly discuss the style he used when building his house and why). With the modern house museums today, the main theme is the architecture, with the social history supporting the architectural interpretation. These sites interpret the architect's intent and vision, and how this was carried out through the structure. Going through these houses, the visitor is told about the architectural elements, and how these elements support the architect's overall design concept.

Fallingwater (1934-1939 in Mill Run, Pennsylvania) (image 3) is considered to be one of the most significant examples of modern architecture in America; therefore, Frank Lloyd Wright's design for the Kaufmann's weekend home is the main theme for its interpretation. The social history of the site is used in order to support the main theme of architectural significance. The architecture is discussed throughout the interpretive tour by tour guides, pointing out and discussing the architectural elements and how they contribute to Wright's vision for the design. When the social history of the site is discussed, it is usually in relation to how the Kaufmann 
family used the space or the relationship between architect and client, all relating back to the architecture and Wright's design.

The Western Pennsylvania Conservancy states that one of their missions is "to demonstrate by the example of Fallingwater the powerful result that can be achieved through the harmonious union of man's work with nature” through the interpretation of its architectural elements. ${ }^{75}$ At each stopping point, inside and outside of the house, guides explain significant architectural elements as well as the social history of the house, which supports the mission of demonstrating the design promotes harmonious living between man and nature. Part of the social history of Fallingwater is telling stories about how the Kaufmanns used the spaces, which is how they were able to live harmoniously with nature through Wright's design.

The Gropius House (1938 in Lincoln, Massachusetts) (image 2) also has the main interpretive theme of a modern architectural design. Like other modern house museums, the social history that is interpreted supports the architectural interpretation. Here the social history is told by discussing the background of Gropius designing the house, and how he and his family’s needs dictated his designs. Gropius’ background as an important architect is also interpreted. There are two themes for interpreting the architecture at the site: New England architecture with the Bauhaus approach and Gropius’ design for maximum efficiency and simplicity. $^{76}$

As with both Fallingwater and the Gropius House, the Farnsworth House’s (1951 in Plano, Illinois) (image 4) interpretive tours’ main theme is the architecture designed by Ludwig Mies van der Rohe. Visitors are told about Mies’ design aesthetic and how the architectural elements of the Farnsworth House fit into the aesthetic. The social history of the site supports

\footnotetext{
${ }^{75}$ Western Pennsylvania Conservancy mission statement for Fallingwater (accessed March 22, 2012).

${ }^{76}$ Gropius House Tour Outline, 1.
} 
Mies' architectural design for the house, which is dominated by the relationship between architect and client, and how Dr. Farnsworth used and felt about the spaces and design features.

\section{Introductions of Tours: The Necessary Background Information}

With most modern house museums, the basic history of the residents, architect, and the site is briefly given at the beginning of the tour. This is done in order for visitors to understand the context in which the house was built. The basic background tells why and how the house was built, and it helps visitors understand the decisions the architect made for the designs. At Fallingwater, the Farnsworth House, and the Gropius House tour guides discuss the brief history of the residents, how they came into possession of the property, and why they chose the architect for their home (at Fallingwater and the Farnsworth House).

This social history of Fallingwater is integral part understanding the architecture. It is interpreted throughout the site, from the background of the family, Wright, the relationship between architect and client, and the site, to stories that happened in the spaces. ${ }^{77}$ Basic information about the family, architect, and the site give visitors the context in which the house was built.

The history begins with the Kaufmann family. Edgar Kaufmann, Sr. (1885-1955) was the owner and the operator of the Kaufmann Department store, a Pittsburgh, Pennsylvania institution since the 1870s. Edgar J. Kaufmann Sr. took leadership of the store in 1919 until his death in 1955. The store was known for its innovative retail spaces, and for bringing good design to the area through its collaboration with the Museum of Modern Art. Kaufmann's wife Liliane (1889-1952) was also active in the department store, and was devoted to the public

\footnotetext{
${ }^{77}$ All interpretive information from Fallingwater Interpretive Guide.
} 
health of the area. Their son, Edgar Kaufmann, Jr. (1910-1989) was a student of architecture and the arts and became a Frank Lloyd Wright scholar, a curator at the Museum of Modern Art, and professor at Columbia University. The entire family was "committed to the ideals of living in harmony with nature, and of the value that good design brings to everyday life.” These ideals and values are what brought the family to commission Wright for the design of their vacation home in $1934 .^{78}$

Frank Lloyd Wright (1867-1959) was an American architect who was a key figure in the development in modern architecture, with a long and expansive career, and an infamous personal life. He started his career working under Louis Sullivan, until he was fired for taking outside commissions. Wright developed modern, organic architecture, beginning with the prairie style houses. Just as Wright was establishing himself as an architect, personal scandal brought his career to a halt in the early 1900s. When he was sixty-seven, he visited Bear Run for the first time, when he was commissioned for the Kaufmann weekend retreat home. After the completion of Fallingwater in 1939, Wright's reputation was revived, and he went on to build over 200 more buildings until his death in $1959 .^{79}$ Fallingwater is significant in Wright's career because it brought him back into the spotlight at the time it was completed, and it is considered by many architectural historians to be his masterpiece.

The Kaufmanns owned the property to use as a vacation retreat to escape the everyday stresses of Pittsburgh and the city's summer heat and population. This area served as a place for their employees at the department store to use as a retreat as well, staying at the camp the Kaufmanns provided up until the depression of the 1930s. The family and employees would go to the woods for refreshment and renewal. The Kaufmanns stayed in a rustic cabin upstream

\footnotetext{
${ }^{78}$ Fallingwater Interpretive Manual, revised 2009, n.p.

${ }^{79}$ Ibid., n.p.
} 
from where they would later build their famous home. As Edgar and Liliane Kaufmann grew older, they wanted a more comfortable place to stay further away from the highway, near their favorite place on the property. Edgar Kaufmann, Jr. convinced his parents to commission Frank Lloyd Wright, with whom he had studied at Taliesin in 1935. Both the Kaufmann family and Wright shared a love and understanding of living harmoniously with nature, which made an ideal patron and architect relationship. The project was commission in 1935, and a year later construction began on the main house. Construction was completed in 1939 with the guest house. Immediately after the completion of the main house in 1937, it became a world renowned architectural masterpiece, boosting Wright’s reputation. It was captivating “for its close integration with its surrounding landscape and for its bold, cantilevered construction over a waterfall.” The family continued to vacation at the house for over twenty years. ${ }^{80}$

This basic social history of the house is told to visitors at the very beginning of the tour, which is located at the bridge leading to the entrance of the house (image 20). Here the brief history of the family, the site, and the commissioning of the design is given. This part gives enough background information to allow the visitor to understand the more detailed information given during the tour.

As at Fallingwater, the Gropius House tour discusses the basic historical background at the beginning outside the front entrance (image 21). The tour guide explains who Walter Gropius was and how he came to prominence in the architectural world, stating he was one of the leading architects in the International Style movement in Europe and that he created the Bauhaus school in Germany to teach modern philosophies in art and architecture. Another point about Gropius' history that is mentioned at this point is his leaving Germany before World War II, and

\footnotetext{
${ }^{80}$ Fallingwater Interpretive Manual, n.p.
} 
he moved to America. The final point given about his history is how he ended up in Lincoln, Massachusetts after being recruited to teach architecture at Harvard University. ${ }^{81}$

At traditional historic house museums where a significant figure is interpreted, much of the interpretation is about why the site is so important to history. The Gropius House is similar to this because Gropius' significance is interpreted. What makes it different, though, is that Gropius' significance is his influence in modern architecture, and this part of the interpretation is to support the architectural interpretation. Gropius's career consisted of being a designer, educator, and critic. He was one of the few inventors of modern architecture (was part of the Deütscher Werkbünd and helped create the factory aesthetic), and was the founder of the Bauhaus and became one of the most influential architectural teachers. ${ }^{82}$

At the beginning of the tour where Gropius' professional background is given, his Bauhaus philosophy is also introduced. Here, the guide discusses Gropius’ historical background, including how Gropius was a German-born architect starting off working under Peter Behrens. Gropius then went on to join the Deütcher Werkbünd and was one of the architect who started the factory aesthetic where function determined the design. Then Gropius founding the Bauhaus is discussed and what he wanted to teach at the innovative school in Germany, where the main principle was to create a unity between the arts and teach modern philosophies about collaborative efforts in design. ${ }^{83}$ This information becomes important later in the tour so the visitor is made aware of concepts brought up later in the tour as architectural elements in the house are discussed.

The basic background information at the Farnsworth House is discussed when the interpretive tour is moving down to the house from the visitor's center. The background

\footnotetext{
${ }^{81}$ Gropius House Tour Outline, 1.

82 James Marston Fitch, Walter Gropius (New York: George Braziller, Inc., 1960), 7.

${ }^{83}$ Dennis Sharp, Bauhaus, Dessau: Walter Gropius (London: Phaidon Press Limited, 1993), 2.
} 
information given is about Dr. Edith Farnsworth, Mies van der Rohe, how their meeting led to this collaboration to build her weekend retreat, and about the second owner of the property, Lord Peter Palumbo. The tour stops at different points along the walk down to the house.

At the first stop the basic background information is discussed at the wooden bridge to inform the visitors about the people who are part of the site's history. The visitors are told about Dr. Edith Farnsworth and how she was a prominent doctor in Chicago and all the accomplishments that made her such a successful nephrologist. This location is also where the background of Mies van der Rohe is given. The guide briefly describes Mies’ architectural career and that he was one of the main architects of the International Style along with how he moved to the United States, specifically the Chicago area, before World War II in 1937. The third person who is part of the history's site discussed here is Lord Palumbo. Visitors are told about how he is a collector of modern architecture and art, and that he purchased the Farnsworth House to add to his architectural collection (which also includes Wright's Kentuck Knob). The guide also informs the visitors about how Palumbo purchased the Mies-designed furniture with the help of Dirk Lohan, Mies’ grandson. ${ }^{84}$

The tour proceeds until it comes to a second bridge where the history of the site is discussed. Dr. Farnsworth's purchase of the property and the meeting between her and Mies is the topic of this stop. The guide starts with Dr. Farnsworth purchasing the property outside of Chicago along the Fox River to build a weekend vacation home. Then the guide tells the story how the two met after Mies’ move to Chicago in 1937, and the two becoming close due to their common intellectual interests (including architecture, art, and literature). This lead to the commission for the house in 1945, and the guide explains the circumstances of the personal

\footnotetext{
${ }^{84}$ Farnsworth House Tour, Plano, Illinois, August 2, 2011.
} 
fallout between the two after the house was completed. ${ }^{85}$ It is believed that the two had an affair and Mies lost interest in Dr. Farnsworth after she commissioned the house. Dr. Farnsworth also complained about the design not being exactly what she wanted after moving into the house. ${ }^{86}$

\section{Architecture as Main Interpretive Theme}

The main significance of these modern homes is the architectural design, therefore when they become museums; the main interpretive theme is the architecture. The interpreter takes the visitors through the spaces and discusses the architectural elements and how they are important to the overall design.

At Fallingwater, the majority of the interpretation is about the architecture of the house: Frank Lloyd Wright's design of promoting harmonious living with nature. The interpretation of the architecture includes the structure and materials, and different architectural elements that are highlighted throughout the tour.

Because of the innovative engineering and design, much of the interpretation is about the structural and material aspect of the house’s design. Throughout the tour, the guides discuss the structural engineering, especially when it comes to the cantilevered terraces and their support. Also the materials are integral characteristic to the architectural interpretation. This is especially true when it comes to conveying the use of the locally quarried stone, the steel supports painted Cherokee red, and use of the windows bringing the attention outdoors. For example, in the living room the guide brings visitor's attention to the use of windows, that they are at the height to make the occupants look straight outside to the landscape, to the fact that Wright made the

\footnotetext{
${ }^{85}$ Farnsworth House Tour.

${ }^{86}$ Farnsworth House Director, Whitney French, explained that tour guides are told to discuss the factual evidence about the relationship between Mies and Dr. Farnsworth, and then let the visitor make up their own mind about what they believe to be true.
} 
windows span the entire wall, and that they are almost seamless to make it appear as though there is no barrier (image 22).

Many architectural elements are discussed in the interpretation. One example is the hatch located in the living room on the first floor (image 23). Here the visitors are told how Wright incorporated this element as another way to emphasize living harmoniously living with nature. This was also Wright's way of emphasizing the Kaufmann’s relationship with Bear Run.

On the west terrace of the house (image 3), the waterfall inspiring the architecture is interpreted. The tour guide discusses how Wright designed the terrace to symbolize the rock outcroppings, specifically the cantilevered rocks of the waterfall. The use of locally quarried stone adds to the house blending in with the surroundings by blending in with the surrounding rocks. Also on this terrace, the placement on the house on top of the boulders is described to the visitors.

The hatch and terraces are architectural elements that are discussed to teach visitors about Wright's organic architectural philosophy. He felt the architecture had to respond to and fit seamlessly within its surroundings, making it organic. These elements are just a couple examples of where Wright designed the house to tie in with the surrounding nature; the hatch (and other entrances and exits) making indoors and outdoors seamless and the terraces blending with the existing outcroppings.

In the living room, the hearth offers another example of interpretation of Wright's design (image 24). Here visitors are informed of how the placement of the hearth was important to Wright, because he felt the hearth was the heart of the home. He usually places the hearth at the center of the homes he designs (like his home and studio in Oak Park, Illinois and the Robie 
House in Chicago, Illinois), but in the case of Fallingwater, he placed it in the far wall to comply with the Kaufmann's desires.

Edgar Kaufmann, Sr.'s bedroom on the second floor is another space where architecture is a major part of the interpretation. Here the main focus is on the windows, which are part of the vertical core of the house. The corners of the windows are pointed out, because there is no need for structural support, allowing for the glass to meet seamlessly. Also the sound control from the opening and closing of the windows is demonstrated in this space.

At the Gropius House, the main interpretive theme is also the architectural design, and information is broken into three different sub-themes. The three architectural sub-themes are Gropius’ Bauhaus philosophy, the New England architectural influence along with the Bauhaus approach incorporated into the design, and how Gropius designed for maximum efficiency and simplicity. $^{87}$

Gropius was the founder of the Bauhaus School in Germany, and used the Bauhaus philosophies he developed in the architectural design of his New England home. Much of the interpretation is based on how Gropius carried out the Bauhaus philosophy throughout the home. The Bauhaus approach is discussed in the study off the entryway. Gropius' philosophy for the Bauhaus is explained in more depth here, and is also used as support to explain the design of the room. The guide discusses how Gropius emphasized collaborative effort, both at the Bauhaus early in his career and later in 1945 when he created The Architects Collaborative (TAC). Then it is explained how Gropius carried out this collaborative idea in the room. For instance, the desk was built for two people to work at, each having equal space but being able to work together. Also the guide mentions that the design of the house was a collaborative effort by all

\footnotetext{
${ }^{87}$ Gropius House Tour Outline, 1.
} 
three Gropiuses. ${ }^{88}$ Before leaving the room, visitors listen to a tape recording of the architect discussing his philosophy and his ideas on design and education. ${ }^{89}$

In Gropius’ daughter’s (Ati Gropius Johansen) room the interpreter also explains more about the collaborative emphasis of the Bauhaus philosophy, and Gropius’ ideas on education. They explain how Gropius encouraged Ati to create her own space. It shows how the design of the house was a collaborative effort for the entire family, and how Gropius believed that children should be encouraged in creativity. ${ }^{90}$

Although there is a lot of social history discussed to support the architectural interpretation, the main tour information is Gropius’ design for his home. There are three architectural themes of the tour: the Bauhaus influence on architectural elements, the New England architecture with a Bauhaus approach, and Gropius’ design for maximum efficiency and simplicity. ${ }^{91}$ Another one of his Bauhaus philosophies is that design should be a collective effort and he promoted team-work in the creation of building structures and furniture. He also taught architecture in relation to industrial production, promoting an increased use of machinery in the production of well designed objects. $^{92}$

In the pantry and kitchen, more of the Bauhaus design is explained (image 26). One point about the Bauhaus design used in Gropius' home is the use of the new materials of the machine age. Part of the Bauhaus philosophy and the International style aesthetic is the use of mass-produced materials, making the structures easy to be constructed anywhere. This love of using mass-produced materials the International Style architects shared stems from the new

\footnotetext{
${ }^{88}$ Gropius House Tour Outline, 3.

89 Gropius House tour, Lincoln, Massachusetts, May 22, 2011.

${ }^{90}$ Gropius House Tour Outline, 6.

${ }^{91}$ Ibid., 1.

${ }^{92}$ Hatje, Encyclopedia of Modern Architecture, 43-44.
} 
factories being built that produce these materials (the factories in which Gropius created the aesthetic for). For example, he used a plastic curtain over the window and plastic mass-produced dishes, showing that he thought "plastic was king."93 The use of mass produced and new material exemplifies the design philosophies he created earlier in his career where he embraced new materials produced by machinery. It is then brought up that Gropius uses the Bauhaus palette: black, white, grey, and a touch of red for emphasis (colors of the machine age), which were colors used throughout his career including the Bauhaus building (1925-1926) in Dessau, Germany (image 10). ${ }^{94}$

Gropius' Bauhaus approach is interpreted even in the bathrooms, particularly the master bath. Here the Bauhaus practicality is seen and discussed through the dual sinks and mirrors that allowed both Walter and Ise Gropius to use the space at the same time. Another point made is that all of the items, including the toilet, are mass-produced products ordered from American catalogs. ${ }^{95}$ These mass-produced products tie into the Bauhaus and International Style philosophy because of the architects' love of products that are mass produced in factories.

The basis of Gropius' design for his home is the Bauhaus philosophy, but Gropius also took into consideration the context of the site and incorporated elements of traditional New England architecture into his design. This is also interpreted within one of the three main architectural interpretive theme.

The New England architecture with the Bauhaus approach is another architectural interpretive theme at the Gropius House. One of the main points about the architecture discussed at the beginning of the tour, at the house's entrance explains how Gropius designed the house as a New England home, using modern design to bring the New England architecture into the

\footnotetext{
${ }^{93}$ Gropius House Tour Outline, 4.

${ }^{94}$ Ibid., 4.

${ }^{95}$ Ibid., 4.
} 
twentieth century. Traditional New England architectural elements used at the Gropius House are pointed out, including the fieldstone foundation, white wood exterior, grey trim, and traditional New England plantings with the apple orchard in the front lawn. Gropius brings the New England architecture into the twentieth century by using modern elements, such as the flat roof, white façade, and lack of ornamentation (image 2). ${ }^{96}$

After entering the home, the tour guide points out how Gropius created a modern design out of a traditional New England elements in homes. It is explained to the visitors how Gropius put a modern twist on the traditional New England entry hall (image 27). It is traditional by having two doors for the entrance, and having a central hall. However, he made the design modern by using curtains instead of a door from the mud room for flexibility, and excluded a door altogether for the coat closet to display the coats and hats as artwork. ${ }^{97}$ At the end of the tour on the screened porch (image 28), the use of traditional New England architectural elements is made apparent again. For example, how it is typical of New England homes to have a screened porch, but Gropius designed the outdoor room to be functional all year long. ${ }^{98}$ The siding of the house is another example of where Gropius combined Bauhaus philosophy with traditional New England architecture. He mimicked the clapboard siding of other traditional New England homes, but used modern mass-produced materials as the Bauhaus philosophy emphasized. ${ }^{99}$

The third and final architectural sub-theme is how Gropius designed for maximum efficiency and simplicity. This is mainly interpreted when the materials Gropius picked are discussed, and how the spaces were laid out so the family could use them efficiently. Like the

\footnotetext{
${ }^{96}$ Gropius House Tour Outline, 1.

${ }^{97}$ Ibid., 2.

${ }^{98}$ Ibid., 7.

${ }^{99}$ Ibid., 7.
} 
theme of the Bauhaus philosophy being carried out in the design, much of this architectural interpretation is supported by the social history, specifically how the family used the spaces. This is because the design is supposed to allow for the family to use the spaces efficiently. The simplicity is interpreted through showing how Gropius used modern design, not using ornamentation, and how he was economic, getting the most out of his designs.

This theme is first discussed at the beginning of the tour outside of the entrance (image 21). When the Gropiuses first immigrated to the area, they did not have much money, so they had to be economical with the materials for the structure and the items going into the house (mainly mass produced items purchased from catalogs). For example, in the hallway it is interpreted that Gropius used stock items to build the house to be efficient financially. He ordered these items from nontraditional catalogs, and he wanted to prove that one could design a custom home using catalog items, ultimately making it less expensive. ${ }^{100}$ Also, Gropius used the placement of the house to be economical for heating and cooling. He placed the house on top of the hill to allow breezes to enter the house for natural cooling in the summer, and oriented the house for passive solar heating in the winter. ${ }^{101}$

Gropius encouraged flexible spaces in order for them to be more efficient. This can be seen in the study where it is shown how the space was multifunctional (image 29). It was used as a passageway for the family and guests, giving views of the orchard as one was moving through the room while having the desk seems inconspicuous in the shadow. ${ }^{102}$ As the name of the room implies, it is used as a study that is designed around Gropius' needs by making it private and sound proof when the doors are shut. ${ }^{103}$

\footnotetext{
${ }^{100}$ Gropius House Tour Outline, 2.

101 Ibid., 1.

102 Gropius House Tour Outline, 3; Tour of Gropius House.

${ }^{103}$ Gropius House Tour Outline, 3
} 
The living room also has architectural elements that are interpreted to show how it was designed to be a multifunctional space that was open as well (image 30). It has an open floor plan, allowing the furniture to be moved around in order to make it function in different ways. ${ }^{104}$ The furniture the Gropius' chose for the living room is discussed, making it apparent how the pieces could be used for socializing and as a place for guests to sleep. ${ }^{105}$

In the upstairs hallway, guides acknowledge that Gropius was practical and functional in almost every space with his designs. Visitors are shown how he used wasted space for hidden storage and a sewing nook for his wife. Also, he designed the floor plan so the four bathrooms of the house were grouped together to save pluming and repair costs. Visitors are also shown how the windows on the north side are used to minimize the view of the street and also to reduce heat loss. $^{106}$

Like the modern house museums mentioned above, the Farnsworth House's main interpretive theme is the architectural design of Mies van der Rohe. It is discussed at different areas around the house, giving different perspectives for visitors as they hear about the architectural elements. The guide mainly discusses how Mies’ aesthetic is expressed in this house, and how he did so through the use of materials, mainly glass and steel.

In front of the house, visitors are told about the overall modern design of the house, and how it is Mies’ signature aesthetic (image 31). ${ }^{107}$ The guide describes how Mies used no ornamentation at all in the design, staying true to the International Style. Also the planes of the

\footnotetext{
${ }^{104}$ The open floor plan is an innovation from the modern movement, started by Frank Lloyd Wright to make the spaces flow together more organically in contrast to Victorian homes where each space is separate and can be shut off from the other. The open plan can is also used in order to maximize the use of space in the interiors.

${ }^{105}$ Gropius House Tour Outline, 3.

${ }^{106}$ Ibid., 3.

${ }^{107}$ The Farsnworth House's aesthetic can be compared to his design for the Barcelona Pavilion (1928-29 in Barcelona, Spain) for the 1929 International Exposition. This can be seen in the use of the grid, creating transparency with the use of large glass panes and slender I-beams for support, and choosing volume over mass. These elements can be seen in other buildings such as the Seagram building in New York City and the S.R. Crown Hall on the campus of the Illinois Institute of Technology.
} 
surfaces are described, and how Mies chose volume over mass by pointing out the volumes of the house and the linear emphasis on a grid through the forms. To discuss these elements, the guide talks about how they expressed through the structure, the main elevated interior floor and the multi-level porch/entry. Mies’ use of materials being an important part of his design is also discussed at the time. The guide points out how Mies used mainly steel and glass as a part of his aesthetic as well as part of the construction, much like he designed in the Seagram Building in New York City and the Barcelona Pavilion in Spain (image 13). The steel (painted white) and glass create a smooth and sleek look. The steel adds to the horizontally linear affect with a vertical emphasis through the use of slender supports lifting the structure and holding the planes of glass. 108

The architectural interpretation is continued as the tour progresses to the interior of the house (image 32). As visitors are moving from the exterior into the interior they are told about the cohesiveness between indoors as outdoors because Mies’ design makes the transition nearly seamless because of the floor-to-ceiling glass. The lack of seems at the doorway is pointed out to emphasize this design element. Also mentioned are the square stones continuing from the exterior landing into the interior of the home uninterrupted without the grid being broken up to emphasize the seamlessness. ${ }^{109}$

The living room is where Mies’ interior architectural design is discussed (image 33). The guide shows how the layout and the built-in consoles/ fireplace are integral to the overall design concept. The wing walls of the interior near the center are used for subtle separation between the different spaces on the entirely open floor plan. Also the layout of the interior console, the placement of the fireplace, and the furniture layout are identified as adding to the linear emphasis

\footnotetext{
${ }^{108}$ Farnsworth House Tour.

109 Ibid.
} 
because they are all on a grid pattern, but situated to be asymmetrical by placing the void of the fireplace at one end and using differently sized furniture opposite each other. The guide shows how Mies hid the electrical elements that he thought took away from his minimalist aesthetic by opening the cabinets in which they are hidden. ${ }^{110}$ The modern aesthetic Mies embraced is the main topic of the kitchen area (image 34). The guide discusses the use of Alcoa stainless steal for the countertops which add the sleek design, and how it was becoming popular to use in commercial kitchens of the time. ${ }^{111}$

The way Mies’ modern aesthetic is discussed in the interpretation at the Farnsworth House is similar to Wright's organic architecture being discussed at Fallingwater and Gropius' Bauhaus philosophy being discussed at his home in Lincoln, Massachusetts. Each of these sites make the architect's design philosophy or aesthetic as the main interpretive theme of their respective house design.

\section{How Social History Interpretation Supports Architectural Interpretation}

Although the architecture is the main theme of modern house museums, the social history of the sites is also discussed. Where other house museums have the social history as the main interpretive theme, the social history of modern house museums is used to support the architectural interpretation. This is usually done through discussing how the occupants used the designed spaces and the relationship between architect and client.

\footnotetext{
${ }^{110}$ Farnsworth House Tour.

111 Ibid.
} 
Interpretation of How Occupants Used the Designed Spaces

At Fallingwater, part of the social history interpreted throughout the house is about the Kaufmanns and their uses in the spaces. One example of this is in Liliane Kaufmann's room (image 35). Here tour guides discuss her personal style and recreational habits. Her eye for design, especially in Fallingwater is mentioned here, as well as her love of swimming. Another example is in Edgar Kaufmann, Jr.'s room and study on the third floor of the house. Here the interpreter discusses how he switched his bed from one space to the other more naturally lit space, because he wanted to wake with the sunrise. It is here the visitor hears about Edgar Kaufmann, Jr.'s background in the arts and architecture, mainly about his being a curator at the Museum of Modern Art.

The Gropius House also uses the social history as a supportive theme for the architectural interpretation, although it is emphasized more particularly since it is the home of the architect. Also it makes the Gropius House more comparable to historic house museums by interpreting a significant figure in architectural that lived in the home. Social history is also used in the interpretive tour to describe how the family used the spaces of the home. Along with the other social history discussed, it is to support the architectural interpretation. Gropius’ emphasis on efficiency is conveyed by how the family's use of the spaces affected his design for the house.

One story of how the family had an influence on the architecture involves where Gropius designing around having a teenage daughter. In the study visitors hear about the spiral staircase on the outside front façade of the house that leads up to Ati's bedroom (image 2). It is discussed in this room because it is easily seen outside of the window. ${ }^{112}$ The guide explains that Gropius added this exterior staircase so that Ati's friends who came over frequently could go straight to her room. It is also explained that Gropius placed the staircase there because he would be able to

\footnotetext{
${ }^{112}$ Gropius House Tour Outline, 3.
} 
see who was coming in and out from his desk, making sure teenage boys were not sneaking into his daughter's room. ${ }^{113}$ This supports the Bauhaus philosophy of collaboration because it shows how Gropius worked with his daughter to create an architectural element that fit the needs and wants for the both of them.

Another area where the way the family used the space is interpreted is the dining room (image 36). Here in this space for small scale living and entertaining, the Gropius’ love of entertaining is discussed. The Gropiuses placed a small round table in the center of the room for small groups, but for larger groups there is a sideboard buffet style table along the inside wall. Walter Gropius and his wife designed the room so they could execute well-planned dinner parties. The tour guide then describes the parties the Gropius' had, and illustrates how the layout of the dining room helped their guests socialize easily. ${ }^{114}$ The efficient use of space in the dining room supports the architectural interpretive theme where Gropius designed for maximum efficiency, because the design allows for the Gropius' to use the entire space efficiently for their dinner parties.

Near the end of the tour on the screened porch, more stories of how the family used the space are told (image 28). In the summer, the screened porch was used as an outdoor living room, while in the winter it functioned as a playroom. The tour guide provides photographs of the Gropiuses using the spaces in both seasons. ${ }^{115}$ The screened porch is another example where the efficient architectural design interpretive theme is supported by showing how the space can function for each New England season.

At the Farnsworth House, part of the interpretive social history is about how Dr. Farnsworth used the spaces that Mies van der Rohe designed. This interpretation is much like

\footnotetext{
${ }^{113}$ Gropius House tour.

114 Gropius House Tour Outline, 4.

115 Ibid., 7.
} 
the interpretation at Fallingwater and the Gropius House, but it is not discussed as much as the other sites, keeping most of the short tour dedicated to the architecture. ${ }^{116}$

The only time Dr. Farnsworth's use of the house is discussed in the first half of the tour is in the living room where her furnishing of the home is addressed. The guide discusses this by using pictures of the house while she lived there. Visitors are told how Dr. Farnsworth did not own the furniture that is currently there or any Mies designed furniture, instead she used excess furniture from her main home in Chicago.

After the tour moves into the bedroom, more about of how Dr. Farnsworth used the spaces is discussed (image 37). It is pointed out this space is closer to how it looked when she owned the house. The interpretation offered in the kitchen is where most of the stories about her use of the spaces are discussed. The guide tells the group how she felt about the transparency of the house. Its is a story about how Dr. Farnsworth would go into the kitchen first thing in the morning, open up the curtains, and there would be people in the yard taking pictures of the house.

Interpretation of Relationships between Architects and Clients

A social history sub-theme in modern house museums, along with how the residents lived in the home, is the relationship between architect and client. This can be seen in Fallingwater and the Farnsworth House's social history interpretation. Both sites have an infamous story about the relationship between the client and the architect they hired. It is an integral part to the architectural interpretation since the relationship had an influence on the final design.

\footnotetext{
${ }^{116}$ The tour at the Farnsworth House is shorter than the tours of Fallingwater and the Gropius House, mainly due to the smaller structure and lesser amount of spaces.
} 
At Fallingwater, a space in which the relationship between architect and client is mentioned is the hatch (image 23). Edgar Kaufmann, Sr. questioned the functionality of the steps down to the stream, but Wright kept them in his plans. Another area where Edgar Kaufmann, Sr.'s questioning Wright's design is told is on his bedroom terrace. The story tells how Kaufmann consulted an engineer about the structural integrity of the cantilevered terraces Wright designed, causing Wright to get angry with Kaufmann. Another incident where Wright became angry with Edgar Kaufmann, Sr. is in his bedroom (image 38), where Wright designed a small built-in desk. Kaufmann jokingly said he could not even write a check at the desk, leading Wright to design a larger desk and leaving a space for a hinged window to swing open.

At the Farnsworth House, the relationship between architect and client is an infamous story. Director Whitney French feels that this is an important part of the interpretation because it helps people relate to the site's history. It is kept minimal in the interpretation, addressing only to how it affected the design. Besides the relationship discussed at the beginning of the tour as background information, it is kept to the interpretation in the bedroom. The guide talks about how the wardrobe was added to the space, despite Mies’ objections. ${ }^{117}$ Dr. Farnsworth wanted more closet space to keep her clothes in, while Mies felt that since it was only a weekend home she did not need the extra space and also because it would cause more clutter and take away from his design. Dr. Farnsworth insisted that she need it, so Mies reluctantly designed a movable wardrobe. $^{118}$

\footnotetext{
${ }^{117}$ The wardrobe is currently not in the house due to needed restoration work because of a flood. A photograph is shown to the visitors so they can see what space is supposed to look like.

${ }^{118}$ Farnsworth House Tour.
} 


\section{Controversial Issues}

Like many sites, these modern house museums are often forced to deal with controversial issues from the history of the house in the interpretation. Fallingwater and the Farnsworth House especially have controversial issues that interpreters face. These issues deal with family turmoil, scandalous behavior, and personal relationships.

Some of the actions of the Kaufmann family could have been considered scandalous, and there is an interest in the personal relationships of the family members; although, these stories are not discussed on the tours out of respect to the family. When asked about the controversial stories about the Kaufmanns, the guide staff is trained to confirm or deny what is definitely known, but explain that out of respect to the family they cannot comment any further. ${ }^{119}$ These stories include the alleged affairs of Liliane and Edgar Kaufmann, Sr. and Liliane’s rumored suicide at Fallingwater. Another issue that is often asked about on tours by visitors is Edgar Kaufmann, Jr.'s homosexuality, where tour guides are told to confirm this but not go into further detail out of respect to him. ${ }^{120}$

The controversial past between Dr. Farnsworth and Mies van der Rohe, is also an issue with the interpretation at the Farnsworth House. It is rumored that the two had an affair that ended once Mies got the commission to design Dr. Farnsworth’s vacation home. It is apparent they had a friendship, and that it was an intellectual affair; although, many believe the relationship was more physical than just a friendship. When this topic is brought up during a tour, the interpreter is trained to say what some believe to be true, factual evidence, but allow the visitor to draw their own conclusions.

\footnotetext{
${ }^{119}$ Fallingwater Tour, Mill Run, Pennsylvania, March 18, 2011.

${ }^{120}$ Many of these stories (factual and alleged) that get brought up by visitors on tours stem from the book Fallingwater Rising by Franklin Toker, where he discussed the private lives of the Kaufmanns and Wright at Fallingwater.
} 


\section{Conclusion}

The Gropius House, Fallingwater, and the Farnsworth House each are house museums where new philosophies of interpretation are being implemented, making the architecture the significance and main interpretive theme. Throughout the interpretive tours, guides direct visitors' attention to architectural elements, and explain to them how these elements represent the characteristics of the home's aesthetic. The social history of these sites is conveyed mainly to support the architectural interpretation, by discussing the relationship between architect and client or how the client interacted within the spaces and design elements.

Where interpretation at historic houses may mainly discuss architecture, modern house museum interpretation discusses the design of a famous architect, and how the structure is significant in the modern movement. The Gropius House is slightly different because the house belonged to a significant figure in history, but since he was significant because of being an architect, his design philosophy is the main interpretive theme. Modern house museums, including those of the architect himself, are creating new interpretive themes, teaching visitors about the architect's aesthetic and how the modern house fits into the modern movement in architectural history. 


\section{Chapter 3 \\ Preservation of Modern House Museums}

Along with interpretation, modern house museums have different philosophies when it comes to the preservation of the structures. The main interpretative mission of modern house museums is to convey the design of the house to the public, so the main preservation mission is to preserve the design in order to interpret it.

The significance of traditional house museums is the historical event that happened at the site, or the historical person who lived there; therefore, the purpose of the preservation work on the structure is to preserve the historic material to keep the site as original to the period as possible. Modern house museums differ from their traditional counterparts because the significance of modern houses is the architectural design, usually by a historically notable architect. Since the significance of the modern house is the architectural design, the importance is preserving the design of the structure. The modern house museum philosophy of being organic makes the institutions more willing to update materials and techniques instead of replicating the original material, and allows the house to change over time.

Preservation work at modern house museums supports the interpretation of the site. Since the main interpretation theme is the architectural design, working to preserve that design is vital. Modern architectural sites work to maintain the original design so visitors can understand the interpretation. This is in contrasts to the traditional house museum, because the institutions allow patina to show, allowing the history of the site to show.

Traditional house museums, where the mission is to interpret the social history of the site, strive to preserve the original, historic materials of the building. For example, at George 
Washington’s Mount Vernon (image 5), preservationists want to save the material (such as the flooring) that existed when Washington lived there. Modern house museums' first intention is to preserve the historic material, but when necessary they will replace materials in order to preserve the design without altering the building aesthetically.

Fallingwater, the Walter Gropius House, and the Farnsworth House are modern house museums that have been confronted with forming the new philosophies of preservation for modern architecture, and are working on creating standards for this new genre of house museums. These three institutions have a range of preservation standards. The Gropius House is the most traditional of the three, Historic New England practices many of the traditional standards (as they do with their other sites) but is starting to use new standards of preservation that modern house museums are adopting. Fallingwater has established new and progressive guidelines for preservation, while still referencing the Secretary of the Interior's Standards for Historic Preservation. The Farnsworth House is very progressive in their preservation efforts; they are more concerned about keeping the appearance of the house to Mies’ aesthetic than preserving the historic material, making the efforts more about restoration than preservation.

\section{Preservation of the Walter Gropius House}

Although a modern house museum, the preservation work at the Gropius House is the most conservative of the three house museums examined in this study. The house is owned and operated by Historic New England, which oversees historic sites such as the Gropius House (the youngest in age of their properties and their only modern house museum). ${ }^{121}$ Due to the fact that the Gropius House is their only modern house, Historic New England typically takes the more traditional route when it comes to historic preservation.

${ }^{121}$ Judith Scott, Preservation of Gropius House, April 1, 2003, 2. 
Although the Gropius House is more traditional in its approach to preservation of the materials of the structure (siding, flooring, windows, glass, etc.) and the furniture, it go by some modern philosophies as well. Although a historically significant figure is interpreted at the site, Walter Gropius is one of the leading modern architects and created his home based on his own principles of modern design. Therefore it is important to restore and maintain his design as he originally intended since his house exemplifies Gropius’ architectural philosophies. Gropius’ only daughter, Ati Gropius Johansen, has had a major influence on curatorial decisions at the site. She visits the site regularly, and Historic New England takes into consideration her thoughts on how the house and its objects should look.

The work on the Gropius House and its collections falls under the former Society for the Preservation of New England Antiquities (SPNEA, but now known as Historic New England) and its preservation philosophy. The philosophy, written by former SPNEA president Jane Nylander states:

if the objects, buildings, and landscapes from the past are to convey their full meanings to people on the present and future, it is essential that their authenticity be protected and cherished. SPNEA believes that collections in its care must be treated in the most conservative manner through stabilization and traditional maintenance rather than restoration and reconstruction. The goal of our preservation philosophy is to assume that the collections are preserved unimpaired for the education and enjoyment of future generations. ${ }^{122}$

This philosophy shows the institution applies traditional historical preservation philosophies at the sites they manage, including the Gropius House. Their goal is to keep the structure authentic and original to educate their audiences. When an object or building is beyond repair, it is replaced or repaired with the same kind of material. ${ }^{123}$

\footnotetext{
${ }^{122}$ Scott, Preservation of Gropius House, 2.

${ }^{123}$ Ibid., 2.
} 
Historic New England has come across issues with preservation at the Gropius House that they do not see with their other historic homes. Gropius experimented with new materials when he built his home, which was not always appropriate for the New England climate. This has contributed to preservation challenges with the repair and replacement of materials did not hold up in the area's climate, such as the siding on the exterior of the home. Another issue Historic New England saw with preserving the house was the normal wear and tear from being a well-visited house museum.

An example of traditional preservation methods being carried out at the Gropius House is when normal wear and tear from being a public museum happens. The floor coverings are where the most work like this is done. Most of the floor coverings within the home have been replaced at least once over the years. The only original coverings left are the rubber tiles in the bathrooms and the wood underneath the carpet in the maid's room. In keeping with Historic New England preservation policy, these replacements were done with the same type of material originally used.

An example of where traditional preservation standards did not work, and new philosophies of modern house preservation took over, is in the work done on the house's windows. The steel-framed Hopes brand windows were normally used in industrial settings and not in residential ones. The metal frames and single pane glass allowed for a lot of condensation. This condensation and the window flashing caused significant problems over the years, leading to major preservation and restoration work.

Because of condensation problems due to Gropius using the materials unsuitable for the climate on the windows and inadequate flashing, there was much deterioration and corrosion. Much work was done to improve the effectiveness as well as the appearance. Work on the 
windows was done in 1985-1986. At that time preservationists from Historic New England tried to keep the original materials and just tighten them. This work was not very effective, and the same problems persisted. In 1998, a new project was started to fix the window problems. This project incorporated a new design by the engineering firm, Simpson Gumpertz \& Heger, Inc. ${ }^{124}$ They were able to remove the windows, repair and clean them, and reinstall them, but new flashing was required in order to fix their problems. Historic New England's goal is to safeguard the original materials and building methods through historic preservation, but in this case they recognized the original methods were in conflict with the long-term health of the house. ${ }^{125}$ This project illustrates the modern house museum new preservation philosophies that make exceptions to traditional preservation methods to maintain the building and the look of building in keeping the architect's vision for the appearance of the house.

While living there, Gropius did work to the house to retain the modern vision he desired in his designs. Gropius made lists of repair work that needed to be done, and made these repairs during his span of living at the site. This shows how important maintaining the clean, modern design of his house was to him and made it imperative to do the same today in order to interpret Gropius and his legacy as a modern architect. Maintaining the appearance of the house also enables the interpretation of Gropius’s life there by showing how important his designs and home were to him, and that he himself worked to maintain the appearance of the house. The traditional method of showing patina some historic sites apply for preservation by can conflict with this idea. Allowing materials to look their age would not benefit Gropius' design, because the materials he used were important to his aesthetic and he would not want them to look pristine instead of aged.

\footnotetext{
124 Scott, Preservation of Gropius House, 11-10.

125 Ibid., 11-10.
} 
Gropius’s daughter, Ati Gropius Johansen, has been a major part of upholding her father's vision for their family home. She has worked with the staff since Historic New England took ownership of the house in 1983 "to bring the appearance of the Gropius House closer to the time when her parents were living in the home." ${ }^{\text {2126 }}$ Johansen visits the house often, and lets the staff know of changes that need to be made, such as restoring the house and objects inside and objects needing to be moved or replaced (one example is that when the chrome on the furniture and the railings start to tarnish, Johansen points out her father would have wanted them to be polished). ${ }^{127}$ She expresses these needs of the house museum verbally to the staff. The furnishings plan by Elizabeth Redmond in 1987 references her input on curatorial decisions. ${ }^{128}$

It is very important to Johansen that her father's design for her family home be preserved. In an article for the Historic New England Magazine in 2003, Johansen described Gropius’s approach for his design as being "based on a philosophy that he had developed at the Bauhaus school in Germany nearly twenty years earlier. It was based on the time-honored, functional design process of nature: to let appearance be the result of performance, to let beauty is determined by function." ${ }^{129}$ This philosophy Johansen described is why the house's design is significant, and staying true to Gropius's design is important to her so visitors can experience it as he intended. She also goes on to write:

This way of approaching design is seen everywhere within the house. It is a total environmental approach, which means that every visual form and relationship has significance and is illustrative of a coherent vision springing from the core beliefs. These are: that elegant design solutions result from taking a fresh approach to problem-solving; that technology and modern materials are vital components in

\footnotetext{
${ }^{126}$ Peter Gittleman, “The Spirit of the House,” Historic New England Magazine (Fall 2002): http://www.historicnewengland.org/publications/historic-new-england-magazine/fall2002/2002FallPage01.htm/?searchterm=ati\%20gropius 
designing for contemporary needs; and that all materials, whether man-made or organic, must be recognized for their intrinsic characteristics. At my parents' house, this philosophy led to the elimination of the barrier between indoors and outdoors. Plants and objects from nature were set against man-made surfaces in order to highlight the intrinsic beauty of both. No problem during the design process was ignored or simply given over to a stale or inefficient solution. No opportunity to appreciate beauty, whether natural or man-made, was ever missed. ${ }^{130}$

Johansen's comments indicate that every detail of the design of their home was important to her family, making it important that these details remain how they were when they lived there.

Johansen has contributed much insight in almost thirty years to the Gropius House since it became one of Historic New England's properties. She has provided many of the details, such as the personal touches (the family's coats and hats hung in the entry, Ise Gropius's earrings on her dressing table, etc.), arranging furniture and objects how she and her parents would have, and donating many of the objects that were once in the house because "she felt they would illustrate her father's design philosophy." 131 With each visit, she fine-tunes displays, such as the placement of the curtains, fine art, jewelry, place settings at the dinner table, and even the furniture. For example, she advised the staff to add the couch in the living room, although it was not there when her parents were, saying that her father would have loved it (image 30). They never had one because Gropius felt the modern movement never produced a good loveseat. ${ }^{132}$

Johansen has also provided Historic New England with invaluable advice on their restoration efforts. She said that her father was delighted by natural beauty, and was equally "exhilarated by the fresh appearance of industrial products that expressed a forward moving

\footnotetext{
130 Johansen, "Designed for Living."

${ }^{131}$ Gittleman, "The Spirit of the House."

132 Gittleman and Hubbard, Conversation with author.
} 
technology and ingenuity.”" ${ }^{33}$ She stated her father had a fascination with modern materials, and he used them throughout the house with the construction and the furniture ${ }^{134}$ (such as the steel framed windows, laminate Bauhaus furniture, and cork floors). ${ }^{135}$ She told the staff that her parents always refinished the different materials around the house (such as the chrome of the railings and furniture); therefore, she wanted everything refinished like her parents would have done. The Historic New England staff would, however, rather reproduce the item than refinish it since they do not make changes that can not be reversed. ${ }^{136}$ There was even an issue after a professional paint analysis was done on the walls in the living room surrounding the fireplace (image 30), Johansen informed the staff that the color was wrong and her father would have wanted the color to be pure white. ${ }^{137}$ The problem was fixed as best as possible, but because of the concrete material on the wall, it cannot be painted the pure white color originally intended. ${ }^{138}$ The Gropius House staff believes their preservation work to be effective. According to the Preservation of Gropius House overview completed in 2003, the house is in good condition, looking lived in but not shabby. The house interior and exterior reflect the 1960s time frame, and the materials that could not be matched exactly to those available in the 1960s believed to match closely enough to reflect the original spirit. Currently, the only preservation work being done is cosmetic upkeep. ${ }^{139}$

\footnotetext{
${ }^{133}$ Johansen, "Designed for Living."

${ }^{134}$ Ibid.

${ }^{135}$ Scott, Preservation of Gropius House.

${ }^{136}$ Gittleman and Hubbard, Conversation with author.

${ }^{137}$ Ibid.

${ }^{138}$ Ibid.

${ }^{139}$ Ibid.
} 


\section{Preservation at Fallingwater}

At Fallingwater, as with other modern buildings, there is a struggle between preserving the historic material and preserving the design by Frank Lloyd Wright. To confront this struggle, preservation standards have been created and implemented at the site. The preservation work, mainly dealing with repairing the building structurally and the deteriorating materials, exemplifies the new preservation philosophies of modern house museums.

In order to govern the preservation work at the site, former Curator of Buildings and Collections, Justin Gunther, compiled a preservation manual to create standards for the preservation work. This manual takes into consideration the mission of Fallingwater under the Western Pennsylvania Conservancy, while creating a specific mission statement and philosophy for preservation at the site. It also references the Secretary of the Interior's standards and guidelines, and applies them to specific instances at Fallingwater. Each aspect of Fallingwater (including materials and architectural and structural elements) is then discussed by addressing its issues and how the preservation work should be handled.

With all house museums, the mission statement of the institution plays an important part with any preservation work at the site. The Western Pennsylvania Conservancy’s first point in its mission statement for its operation of Fallingwater is "to preserve, maintain and make available

for public education and appreciation Frank Lloyd Wright’s masterpiece, 'Fallingwater., "140 By describing Fallingwater as “Frank Lloyd Wright's masterpiece,” the statement makes plain that the building's significance is the architect's design. As with many museums, the goal is to make their collection or buildings available to the public, and as stated in the mission statement, Fallingwater wants to make Wright's masterpiece available to the public. In order to do this, the

\footnotetext{
${ }^{140}$ Western Pennsylvania Conservancy mission statement for Fallingwater.
} 
Western Pennsylvania Conservancy needs to maintain the design of the house as it originally appeared.

Another purpose of the Western Pennsylvania Conservancy included in the mission statement is "to demonstrate by the example of Fallingwater the powerful result that can be achieved through the harmonious union of man's work with nature.” In order to demonstrate man’s work being harmonious with nature through Fallingwater, they need to show how Wright did this through his organic architectural design by having Fallingwater respond to its natural context and by being "visually and environmentally compatible, closely integrated with the site," and reflect the concern with the process of nature and the forms they produce. ${ }^{141}$ By maintaining Wright's organic design at Fallingwater, the Western Pennsylvania Conservancy achieves their mission of demonstrating the harmonious union of man's work and nature.

The institution also preserves the site because it feels there is no substitute for the experience of the actual place. ${ }^{142}$ Fallingwater's staff works to maintain the atmosphere, as created by Wright, through preserving the site in order to sustain the original impression of the structure through the preservation of the design.

In the "Fallingwater Preservation Manual” the mission of preservation at the site is stated in the introduction. The final statement says its preservation standards mission: the approach of preservation work should be collaborative and meet the highest recognized standards of museum practices. This statement shows thee staff is still aware of and use the standards of traditional institutions.

\footnotetext{
${ }^{141}$ Flemming, Honour, and Pevsner, The Penguin Dictionary of Architecture and Landscape Architecture, 413.

142 Justin Gunther, Fallingwater Preservation Manual, 4.
} 
The aim of preservation at Fallingwater is to retain its cultural significance, along with including provisions for security, maintenance, and the future. ${ }^{143}$ This creates two drastically different agendas at Fallingwater: the structure as a work of art and the experience of place, and the site as a modern museum and its operations. ${ }^{144}$ One of the stipulations Edgar Kaufmann, Jr. had when donating his family's vacation house to the Western Pennsylvania Conservancy was that they maintain the design and experience of the house to demonstrate unity between man and nature, and displaying this to visitors in the most natural way possible. Kaufmann thought in order for visitors to truly experience Fallingwater, there should be as few obtrusions as possible. ${ }^{145}$ He wanted the house to feel as home-like as possible, allowing people to walk through freely without barriers and other typical museum devices, such as vitrines, labels, etc. It is the Fallingwater administration's challenge to make the house museum like a modern museum, in which the building is a technically sophisticated tool that protects the contents and structure from natural elements, time, and man, as well as creating the natural atmosphere as desired by Kaufmann. ${ }^{146}$

The "Fallingwater Preservation Manual” states that, "the goal of all preservation activities at Fallingwater is to maintain the designed relationship of the house with the surrounding natural landscape."147 Fallingwater addresses the problem of Wright's innovative use of technology. One example is the cantilevered terraces and the smooth surface of the concrete which makes repairs difficult, but every effort is taken in order to maintain the structural integrity of the cantilevers and the smooth appearance of the concrete. This means interventions that usually include some loss of authenticity of the cultural property are justified

\footnotetext{
${ }^{143}$ Gunther, Fallingwater Preservation Manual, 9.

${ }^{144}$ Ibid., 8.

${ }^{145}$ Ibid., 8.

${ }^{146}$ Ibid., 8.

${ }^{147}$ Ibid., 4.
} 
by the importance of preserving the structure for the future, such as the new technology and materials used for tensile strength to hold up the cantilevered terraces (image 3). It is recognized by the Fallingwater staff that these problems are unique and are resolved through education, research, and trial and error basis. ${ }^{148}$

There are principles set forth to define this preservation philosophy. These principles point out different areas of preservation at Fallingwater: doing the minimum and least invasive work as possible, preserving and maintaining the design and aesthetic of the building, and maintaining the historic material where possible. Making sure the preservation work is kept at minimum and is the least invasive alternative possible keeps in accord the preservation mission and philosophy by meeting the standards of museum and preservation practices. It states that any interventions should be the minimum necessary and every effort must be taken to make all conservation of the structure as noninvasive and in obtrusive as possible. This means the work to maintain the structural integrity, for example, must be done, but with minimizing the loss of cultural property.

This ties into the principles addressing the issues of maintaining the historic material of the structure, such as the repairs to the concrete finish and the stonework of the floors, inside and out and the walls (image 22). Doing the least invasive and minimal work possible helps maintain the historic material of the site. Any preservation work on Fallingwater must be governed with the respect for the aesthetic, historical, and physical integrity. These principles are part of the Western Pennsylvania’s goal to preserve the building for future generations; although, changes may be made to the original building systems if the changes contribute significantly to the long-term preservation to the building.

\footnotetext{
${ }^{148}$ Gunther, Fallingwater Preservation Manual, 5.
} 
It is important to maintain the historic material and integrity of the building, but it is also important for modern house museums, such as Fallingwater, to maintain the architectural design of the structure as Wright envisioned it. As stated above, preservation must be governed with respect to historical and physical integrity, along with the aesthetic integrity. Because the aesthetic integrity is so important, Fallingwater staff and the Western Pennsylvania Conservancy’s preservation work maintains Frank Lloyd Wright’s original vision. It is also important that no effort be made to revise or improve the original design for aesthetic purposes. This goes back to Edgar Kaufmann, Jr.’s philosophies about Fallingwater as a house museum, as well as his original intent when he entrusted the house to the Western Pennsylvania Conservancy. It is stated in the deed of gift that nothing be added or changed that affects Wright's design. ${ }^{149}$

An example of how the staff at Fallingwater is able to fit their modern philosophies within the standards of a traditional institution is the Secretary of the Interior's standard regarding restoration of deteriorated materials. The standard states that if deteriorated features will be repaired and not replaced, and if the severity of the deterioration requires replacement of that feature, the new feature will match the old in aesthetics and material. It is so important to keep the appearance of Wright's vision, that Fallingwater follows the second part of the standard by repairing and replacing materials but maintaining the original look and using the same material. The only exception to the rule the Fallingwater staff makes is using modern techniques and adding materials to the inner skeleton of the balconies for structural support. ${ }^{150}$

The Secretary of the Interior's standards emphasize the importance of preserving the structure's distinctive features and materials, which is also important to the preservation of

\footnotetext{
${ }^{149}$ Kaufmann, Jr., "Remarks on Fallingwater as Administered by the Western Pennsylvania Conservancy."

${ }^{150}$ Gunther, Fallingwater Preservation Manual, 28.
} 
Fallingwater. One of the most distinctive features of Fallingwater is the cantilevered terraces (image 3). Maintaining the cantilevers structurally is an integral part to Fallingwater’s preservation. Another distinctive feature of Fallingwater is the smooth concrete surfaces. This smooth concrete is also integral to the preservation of Fallingwater, and keeping the surfaces smooth maintains the modern design Wright created. In order to maintain this look, the staff at Fallingwater will repair cracks and add concrete to areas in which the existing concrete has fallen off, but they use the same kind of concrete and finish to maintain continuity with the rest of the house. ${ }^{151}$ This is the same with the rest of the materials of the house: if repaired or replaced, the same material and finish is applied.

An example of Fallingwater implementing their preservation guidelines is in the stonework throughout the interior and exterior of the house. Much work is done every year to repair the stonework used as flooring of the interior, and the terraces and steps of the exterior to fix broken stones and cracked grout. When grout becomes cracked or chips away, it is chiseled out and new grout (a predetermined mix based on the original cement) is added. When the stone is broken, there are two procedures implemented. If it is broken into three or fewer pieces, the flagstone is reset and grout is applied between the pieces. If it is broken into three or more pieces, a closely matching stone is used for its replacement. ${ }^{152}$

One of the most extensive preservation projects at Fallingwater was the structural repair to the cantilevered terraces. In 1994, an engineering graduate student analyzing the strength of the cantilevers found that the terraces were deflecting dramatically and recommended Fallingwater seek out further study. ${ }^{153}$ Robert Silman Associates did this study in 1996, and found that the stresses on the steel beams supporting the terraces were so significant that is was

\footnotetext{
${ }^{151}$ Gunther, Fallingwater Preservation Manual, 28-29.

152 Ibid., 35.

153 The engineering graduate student was John Paul Huguley
} 
actually dangerous. Three of the four first-story cantilever beams needed strengthened and the only way to strengthen them without altering the outward appearance, was to use post-tensioning on the main beams, connecting them to steel cables and using the tension in the cables to relieve the tension in the beams. ${ }^{154}$ This is an example of Fallingwater's and other modern house museums' new preservation philosophies at work. In order to save the structure from falling into the stream below, modern materials and technologies were used to repair and strengthen the supports and terraces in order to maintain Wright's original design. Although the new materials were added to the structure, the appearance was unaltered, keeping with the preservation mission and philosophies that were set. This demonstrates the new philosophies of modern house museums, because the institutions will make some exceptions to the traditional standards of preservation in order to maintain the original design where adhering to strict preservation guidelines would have forbidden this work.

The preservation work at Fallingwater goes hand in hand with and supports the interpretation at Fallingwater. The mission is to make available for public education Frank Lloyd Wright's masterpiece. The interpretation's mission is to present the architecture to visitors and assist in their understanding of the architecture and its significance. In order to do this, preserving the house is essential because it is important for the house to look the way Wright designed in order for the visitor to visually understand the concepts presented in the interpretation.

\section{Preservation of the Farnsworth House}

The Farnsworth House differs from most house museums because of the use of new and progressive standards for preservation. It is the most progressive of the three houses examined

\footnotetext{
${ }^{154}$ Gunther, Fallingwater Preservation Manual, 42.
} 
here, and has a very different attitude toward preservation. The staff of the Farnsworth House and the National Trust for Historic Preservation are more concerned about preserving Mies van der Rohe’s design for the house than preserving the historic material. If it helps preserving the aesthetic Mies intended, replacement of original material is approved by the Director and the National Trust. Through replacing material to preserve the architectural design, the Farnsworth House does more restoration than preservation.

Flooding has been a major preservation issue for the Farnsworth House (image 39). The house is located along the bank of the Fox River, and Mies had designed the house to be elevated by the I-beams in order for flood water to pass under the home, but periodically the flood waters rise high enough to get into the house. ${ }^{155}$ Since the house was taken over first by Landmarks Illinois and the National Trust in 2003, there have been a few instances where major flooding occurred. ${ }^{156}$ Each time a flood happens, the institution does restoration work to fix damages done to the house.

The flood that caused the most significant damage was the one in 1996. The house is elevated five feet off the ground, and the 1996 flood rose to approximately five and a half feet over the first floor and caused about half a million dollars in damages. Most of the repair that had to be done involved refinishing the materials so it looked brand new again. This included the wood finish of the cabinetry. ${ }^{157}$ The wardrobe (one of the only pieces Mies designed for the house) is currently not in the house anymore due to this flood. The piece was so extensively damaged that the piece was taken out until funds can be raised to repair it. ${ }^{158}$ The furniture, rugs,

\footnotetext{
${ }^{155}$ Braulio Agnese, “Farnsworth house flooded,” Architect (1997): 22.

${ }^{156}$ Whitney French, Conversation with author, August 2, 2011.

157 Ibid.

${ }^{158}$ Farnsworth House Tour.
} 
etc. needed to be replaced; but most importantly, the windows were replaced due to the pressure of the river water smashing the glass panes. ${ }^{159}$

In 2008, thirteen inches of the Fox River rose into the house. This time, no structural damage was done and preventative measures were taken to save the furniture from the flood waters; although, the museum was forced to close for a short period of time to clean and repair elements that were damaged, such as the wooden cabinetry. ${ }^{160}$

Because of Mies’ modernist design for the architecture of the house (sleek, unadorned, and white/ light colors), the slightest flaw stands out. That is why preservation and restoration is so important, because it is needed in order to maintain Mies’ design. The Farnsworth House administration and the National Trust will repair and replace materials in order to maintain this aesthetic. Although they will replace the original materials, the architectural intent is never modified or destroyed. The structure, although it may not be completely original, is and always will be the same design that Mies created. ${ }^{161}$ This progressive preservation work has been effective, because visitors are able to experience the architecture as Mies intended without flaws (due to deterioration) being distracting.

Since the National Trust purchased the house in 2003, the house has been in good condition, and is mostly low maintenance aside from flooding damage and major projects. Most of the major problems stem from flooding. Because the flaws stand out in this house and the institution wants to stay true to Mies' vision, the wardrobe that was once in the house is still off site because they would rather have a piece missing than it stay in the house damaged, taking away from Mies’ aesthetic. ${ }^{162}$

\footnotetext{
159 Agnese, “Farnsworth house flooded,” 22.

160 Ibid., 22.

${ }^{161}$ French, Conversation with author.

162 Ibid.
} 
Other major projects have been taken on. One includes the replacement of the roof system. The roof from the 1950s was not working properly anymore, threatening the safety of the interior. To protect the structure for the future, the staff had to replace and modify the existing roof. It was modified slightly, using contemporary technology, but was approved by the National Trust in order to protect the house because the new system did not modify the modern aesthetic of the house. The next project the Farnsworth House is going to undertake is repairing the stone on the exterior travertine steps; they are going to deconstruct it, replace damaged pieces, and put it back together so that it will maintain the sleek grid Mies intended. ${ }^{163}$ Since the structure of the house is so important to the site, there are plans for a study to be done on the steel supports and beams, which are corroding, to determine the best approach to restore or replace them. $^{164}$

Like the original material being altered to better suit Mies’ design, the furniture and interior design has been altered from when Dr. Farnsworth lived in the house. When Dr. Farnsworth moved into the house in 1951, she brought her own furniture with her (which was in the Chippendale style) instead of having Mies design pieces. ${ }^{165}$ In 1972, then owner Peter Palumbo hired Mies’ grandson, Dirk Lohan, to restore the house to its original condition, ${ }^{166}$ as well as to create the interior design like he thought his grandfather would have done if he had the opportunity (image 33). When the National Trust purchased the home in 2003 from Palumbo, they kept the furniture in the house, and received guidance from Lohan on how to arrange the interiors. ${ }^{167}$ This is another progressive idea in traditional house museum standards, because

\footnotetext{
${ }^{163}$ French, Conversation with author.

${ }^{164}$ Kim A. O’Connell, “Modern Marvels,” Period Homes (November 2007).

165 Farnsworth House Tour.

${ }^{166}$ O’Connell, "Modern Marvels.”

${ }^{167}$ Whitney French, Conversation with author.
} 
instead of trying to recreate how the spaces would have originally looked, the spaces were furnished in order to compliment the aesthetic of Mies’ architectural design.

\section{Conclusion}

In conclusion, the staff at these three modern house museums is each at different levels of progressiveness with their different approaches at preservation. At the Gropius House, the most traditional of the three, administrative staff (under Historic New England) work to save Gropius’s design in able to educate visitors on his design philosophies, but still maintain the historic material by not making changes that can not be reversed and using replicas instead of altering an existing piece. Fallingwater, in between the other two houses in terms of progressiveness, has created its own set of guidelines in order to ensure Wright's design for the vacation home are preserved, but they reference the Secretary of the Interior's Standards for the Treatment of Historic Properties. The Farnsworth House, while not having written guidelines, is the most progressive in that they striving to maintain Mies van der Rohe’s International Style design, and by replacing any historic material to preserve the integrity of the architectural design. Each institution varies with their implementation of preservation actions, but all are working toward a new standard of preservation for modern house museums. 


\section{Conclusion}

Modern house museums necessitate changes in house museum policy regarding interpretation and preservation. The Gropius House, Fallingwater, and the Farnsworth House are three examples where these new approaches are being carried out. These sites bring unique circumstances to the house museum world because of their significant architecture, and lead museum professionals to look at how to operate these museums differently. This study has revealed unconventional approaches in interpretation and preservation. These houses have become museums under different circumstances, have different reasons for significance and some are under the operation of different institutions than more typical for historic house museums; leading to new philosophies of operation. The areas of interpretation and preservation are extremely different for modern house museums in comparison to historic house museums.

With the recent emergence of modern house museums, interpretation is now being focused on the architectural design, which is generally the significance of the site. The social history interpretation (the focus of many historic house museums) is used as a secondary theme to support the architectural interpretation. This can be seen at the Gropius House, Fallingwater, and the Farnsworth House. Each of these three sites focus on the architectural design within their thematic tours. When the social history is discussed, it is to support the architectural interpretation, discussing how the occupants felt about and interacted with the design and the relationship between architect and client. These subjects help the audience understand the design and to feel a personal connection to the site.

The preservation of modern house museums has become a widely discussed issue within the modern house museum field. Where historic house museums want to preserve the historic 
material of the structure, modern house museums are more willing to part with the original materials and resort to restoration in order to preserve the design. The three case studies examined here vary in their approaches to preservation, but all have the same mission to preserve the integrity of the architectural design. The Gropius House is the most traditional of the three, where they make changes to the historic material that are not irreversible, but will integrate reproductions into the house in order to keep Gropius’s design pristine. Fallingwater comes in the middle because the staff strives to keep the historic material, but is willing to part with it if it means preserving Frank Lloyd Wright's design. The Farnsworth House is the most progressive with the staff's forward thinking about preservation, they are willing to replace original materials (even with more contemporary materials) to ensure Mies van der Rohe’s design is intact.

As seen throughout this study, modern house museums are unique in the museum field and necessitate unique treatment. Currently there are no national standards set for this new genre of house museum, which is a growing field where more and more modern houses are opening to the public (including Philip Johnson's Glass House built in 1949 in New Canaan, Connecticut opening in 2007). They cannot simply be placed in the same category with historic house museums, because they have different needs. Modern house museum professionals are creating their own standards and guidelines specifically for their sites, while keeping their ethical responsibility to the national standards set by the federal government. Professionals are also addressing these issues in articles, and symposia. For preservation, national standards set by the federal government need to address the best practices for modern architectural sites (as seen at the modern house museums discussed) as well as historic sites. Literature on preservation and interpretation needs to start addressing issues specific to modern house museums. This attention to the issues of modern house museums is important because the sites need to have a cohesive set 
of standards to follow to help professionals choose the appropriate actions for their particular modern house museum.

The purpose of this study is to bring attention to the issues of preservation and interpretation with which modern house museums are faced. This study was also done in order to show the importance for professionals in the field to become aware of these issues so a general standard can be developed. It is my hope for the interpretation and preservation, specifically for modern house museums, to soon be part of professional literature and national standards. 


\section{Images}

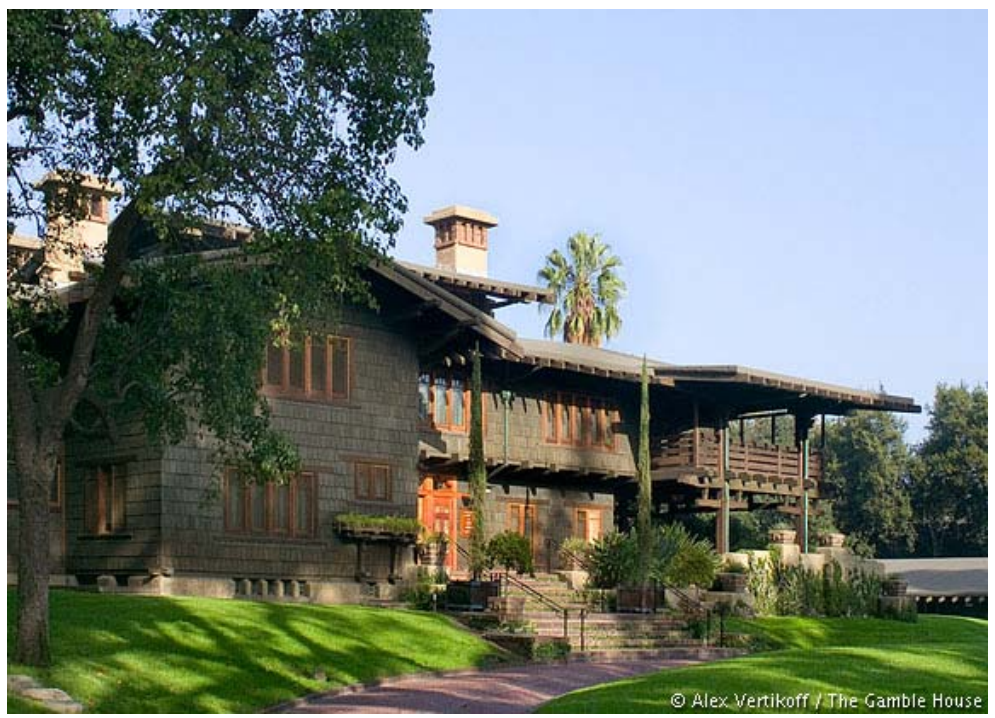

\section{Image 1}

The Gamble House, 1908

Charles and Henry Greene

Pasadena, California

(gamblehouse.org)

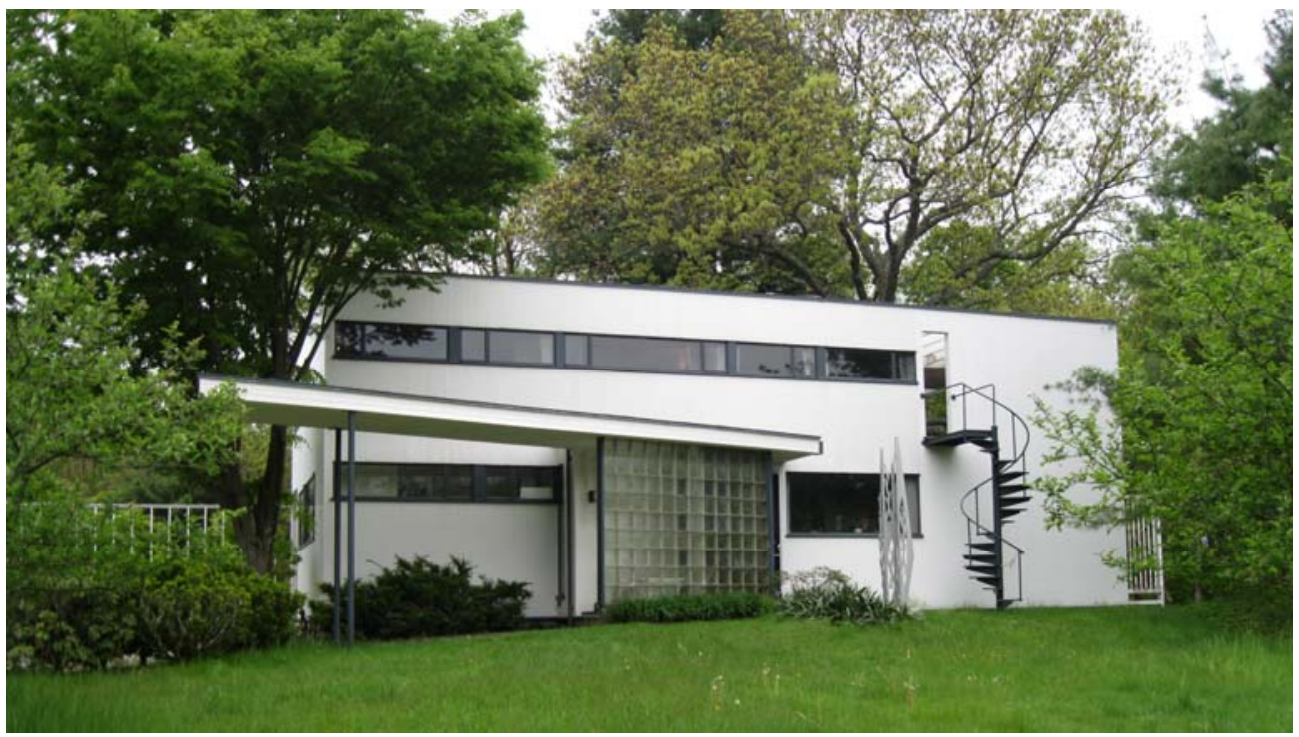

Image 2

The Gropius House, 1938

Walter Gropius

Lincoln, Massachusetts

(photograph by author) 


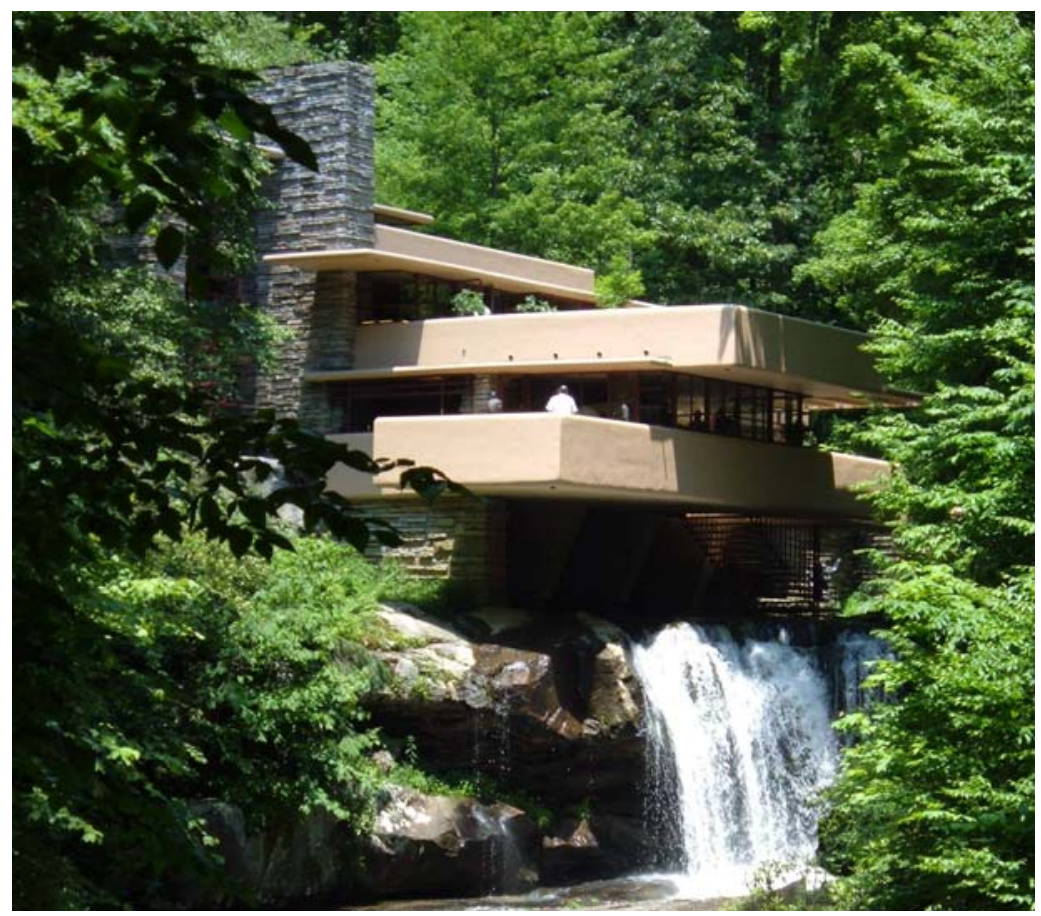

Image 3

Fallingwater, 1934-1939

Frank Lloyd Wright

Mill Run, Pennsylvania

(photograph by author)

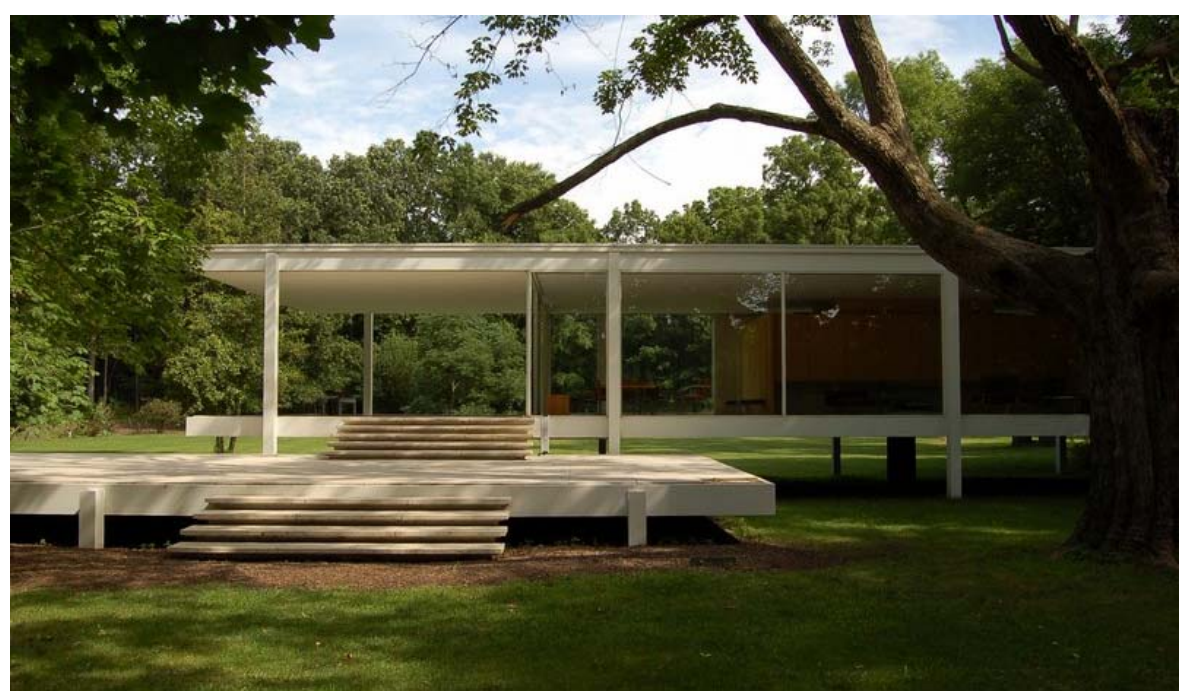

Image 4

The Farnsworth House, 1951

Ludwig Mies van der Rohe

Plano, Illinois

(farnsworthhouse.org) 


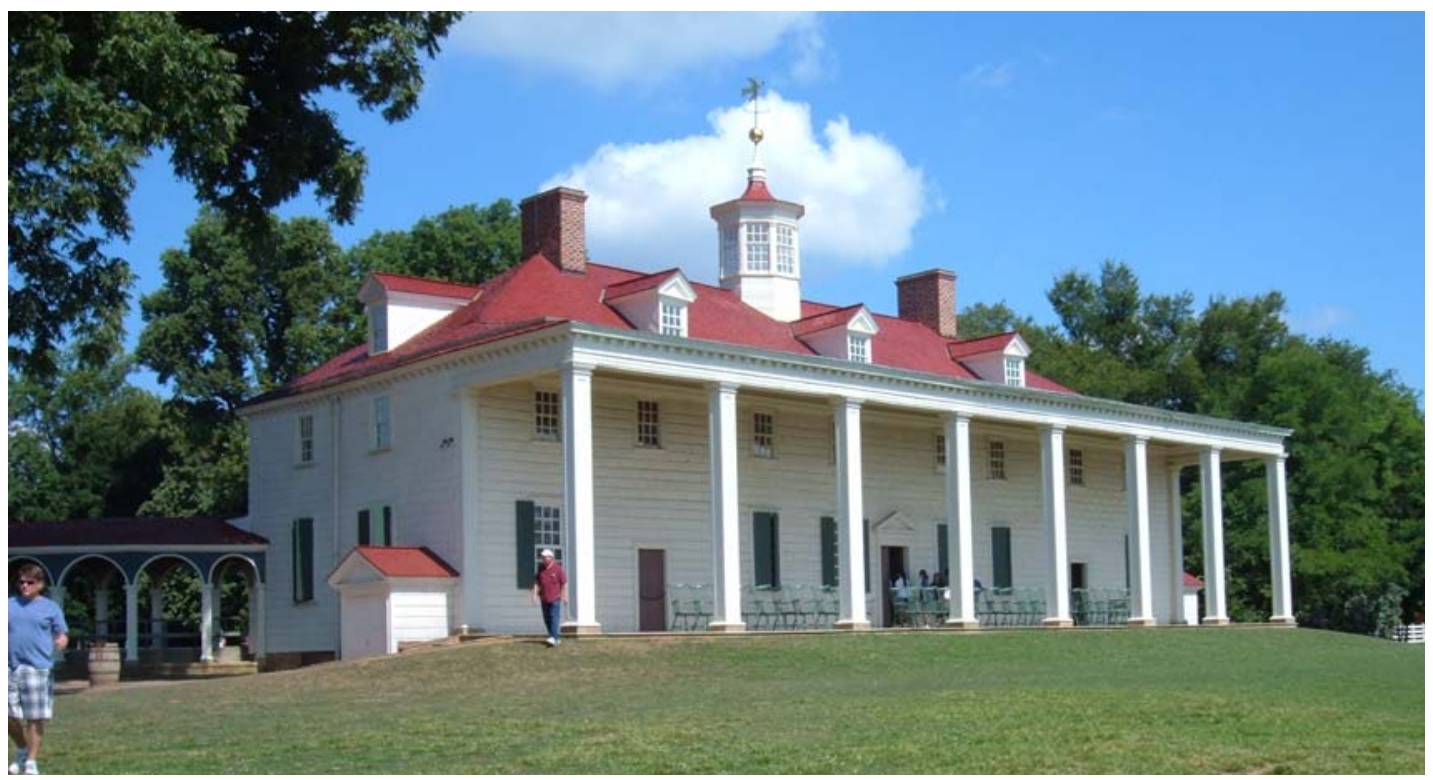

\section{Image 5}

Mount Vernon, 1757-1799

George Washington

Mount Vernon, Virginia

(photograph by author)

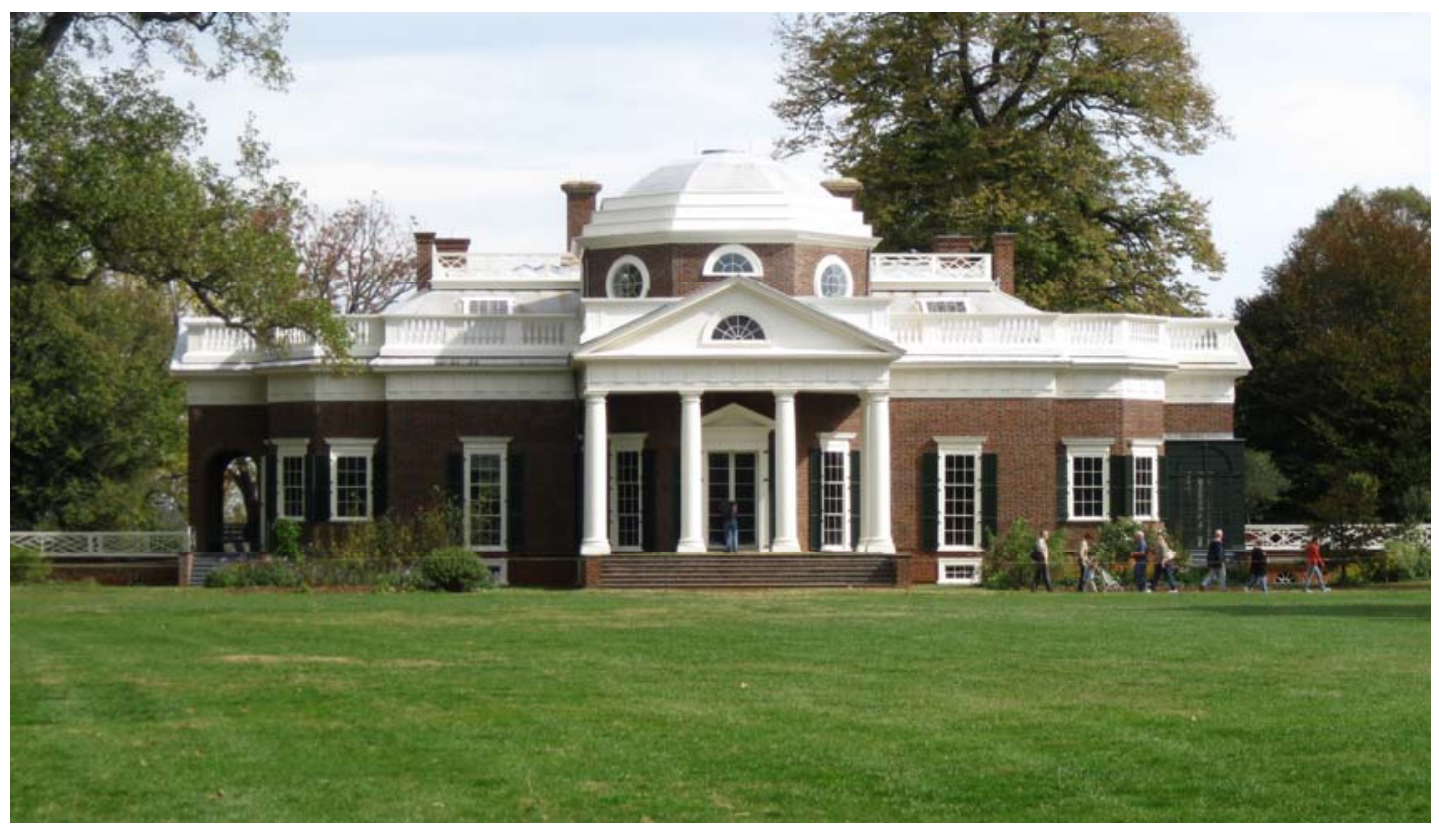

\section{Image 6}

Monticello, 1769-1782

Thomas Jefferson

Charlottesville, Virginia

(photograph by author) 


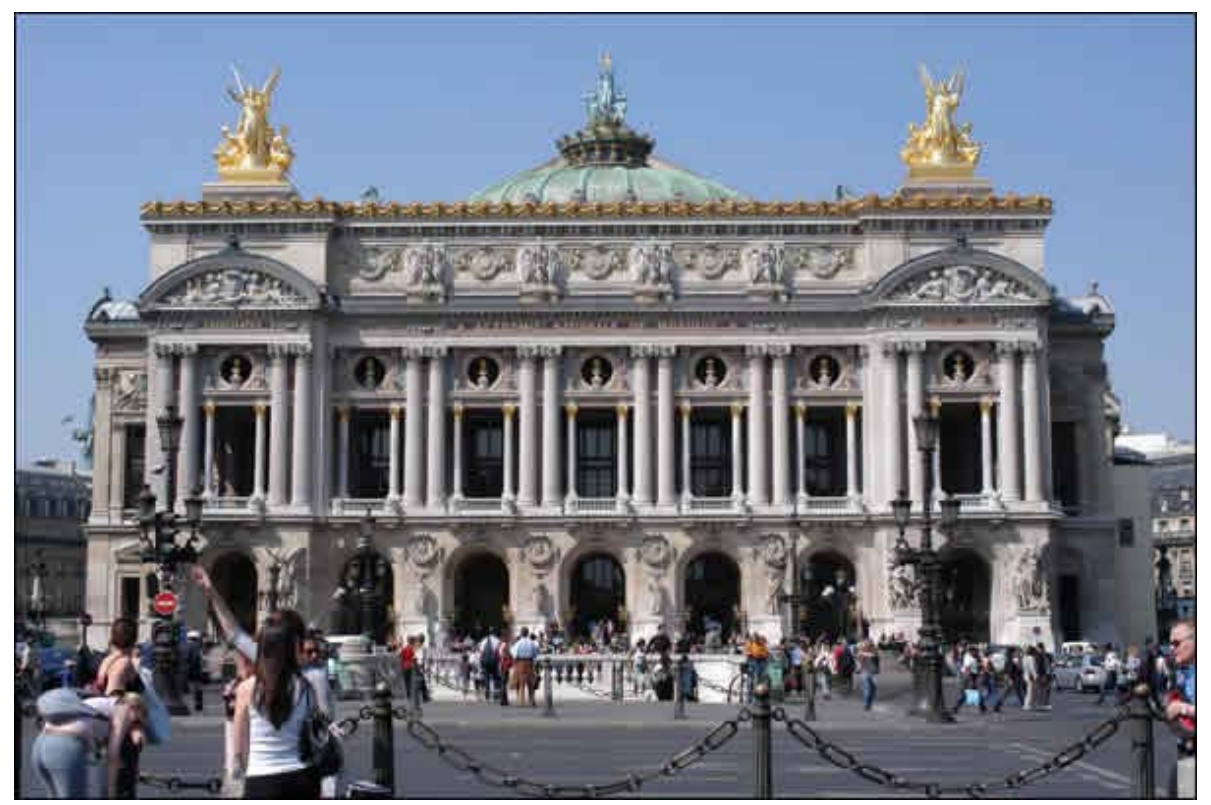

Image 7

Paris Opera House, 1857-1874

Charles Garnier

Paris, France

(http://paris-eiffel-tower-news.com/paris-stories/paris-story-opera-house-garnier.htm)

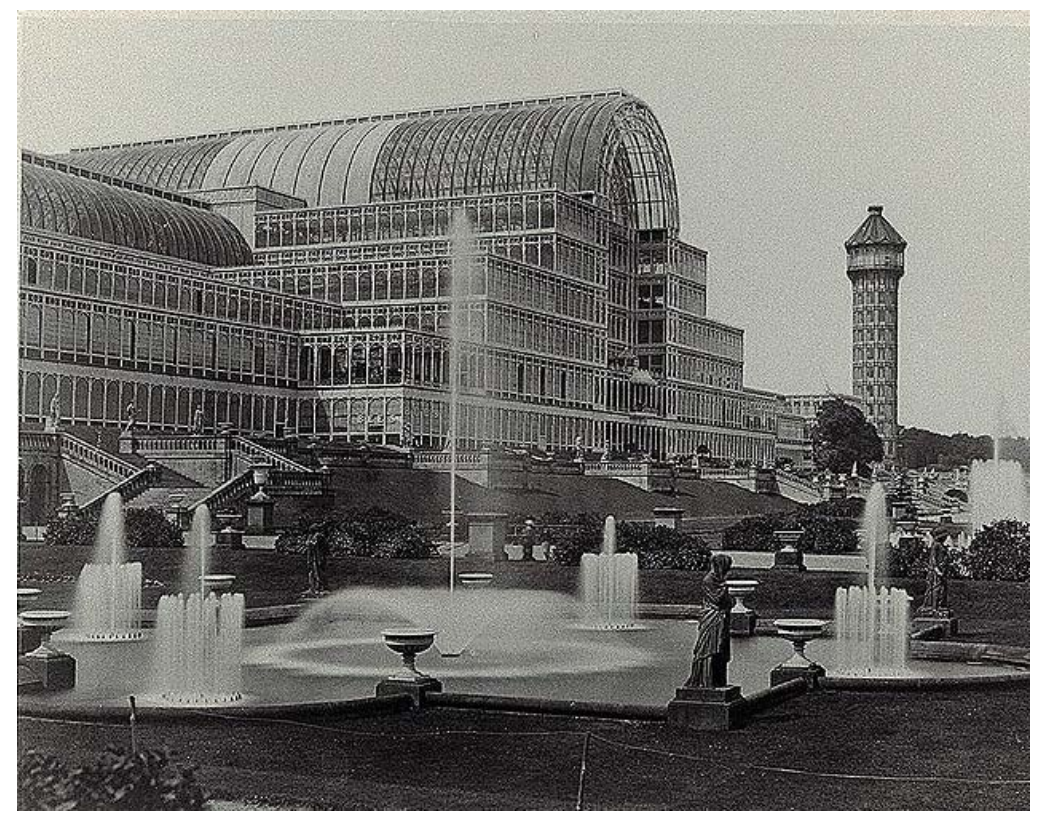

Image 8

Chrystal Palace, 1851

Joseph Paxton

London England

(http://www.designhistorylab.com/students/peters/?p=412) 


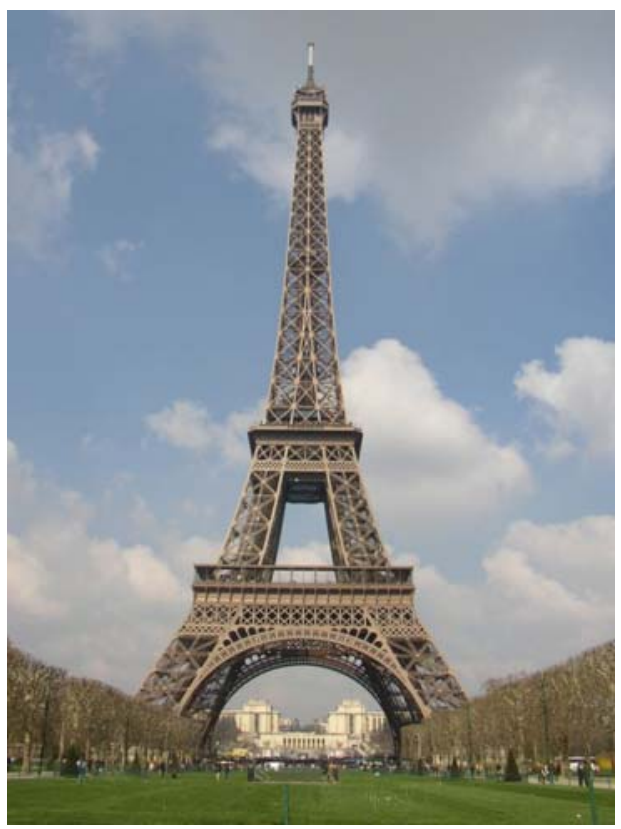

Image 9

Eiffel Tower, 1899

Gustave Eiffel

Paris, France

(http://www.eiffel-tower.us/Eiffel-Tower-Why-Was-the-Eiffel-Tower-Built.html)

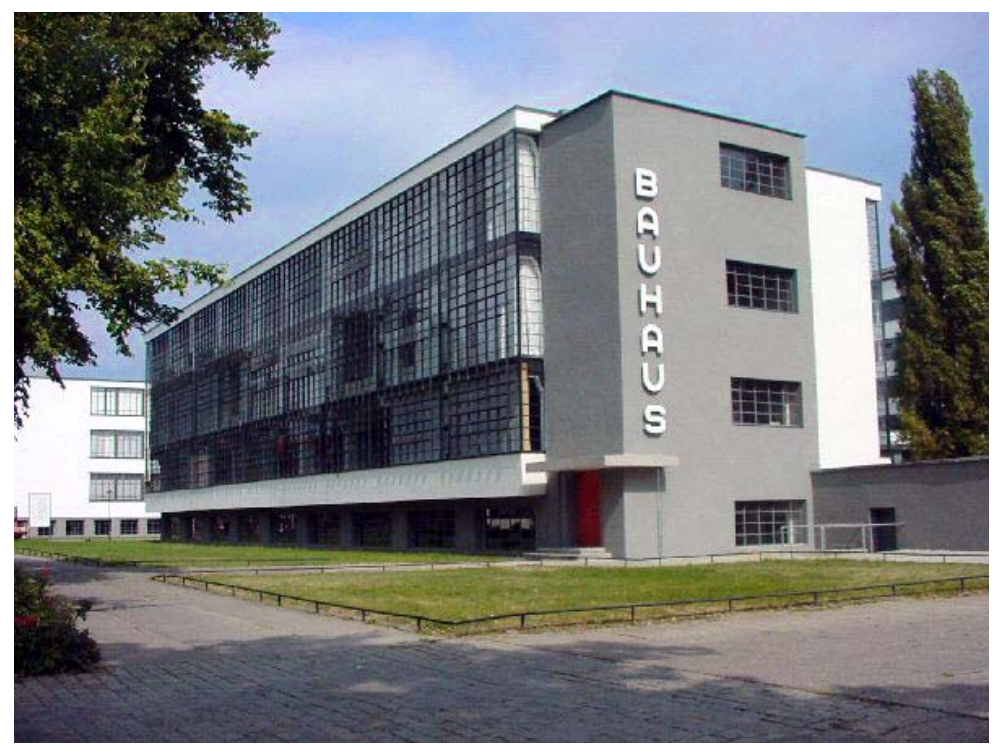

\section{Image 10}

Bauhaus, 1925-1926

Walter Gropius

Dessau, Germany

(http://en.wikipedia.org/wiki/File:Bauhaus.JPG) 


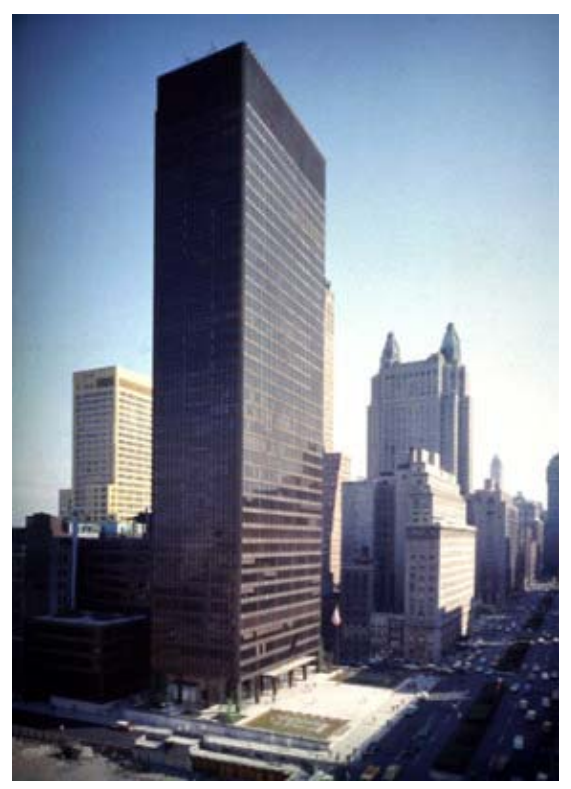

Image 11

Seagram Building, 1958

Ludwig Mies van der Rohe

New York City, New York

(http://s873.photobucket.com/albums/ab294/berginarchitects/Seagram\%20Building/?action=vie w\&current=joh0-023.jpg\&sort=ascending)

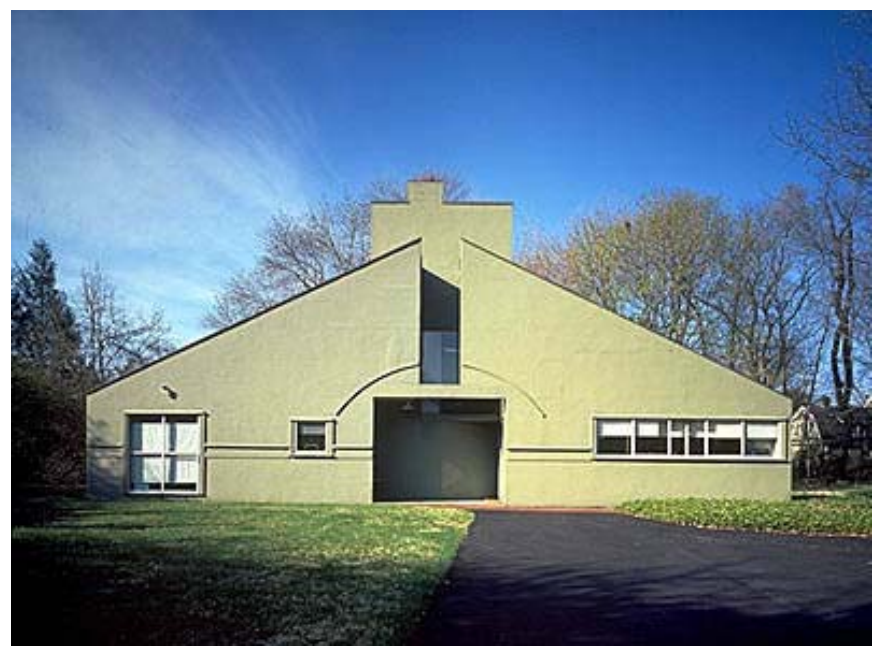

\section{Image 12}

Vanna Venturi House, 1964

Robert Venturi

Philadelphia, Pennsylvania

(http://architecture.about.com/od/greatbuildings/ig/Modern-and-Postmodern-Houses/VannaVenturi-House.htm) 


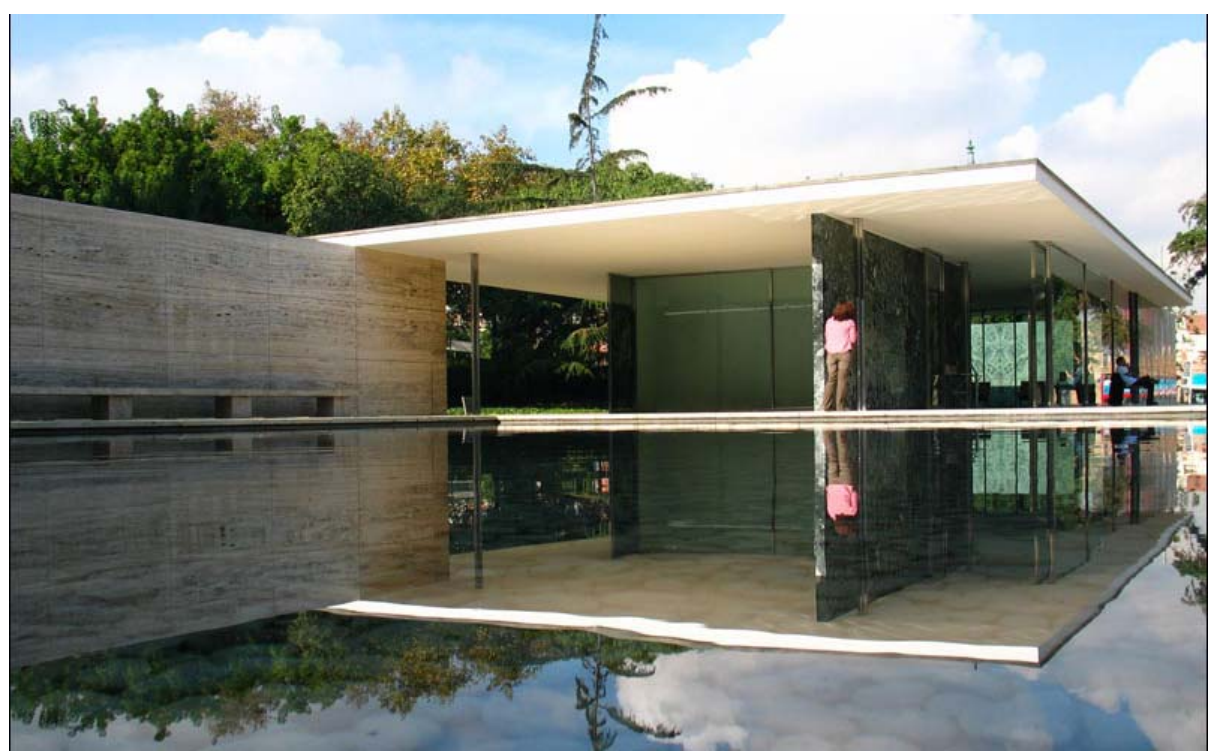

Image 13

Barcelona Pavillion, 1929

Ludwig Mies van der Rohe

Barcelona, Spain

(http://ccainteriordesignfall2010annamaciel.wordpress.com/2010/10/18/barcelona-pavilionstudy/)

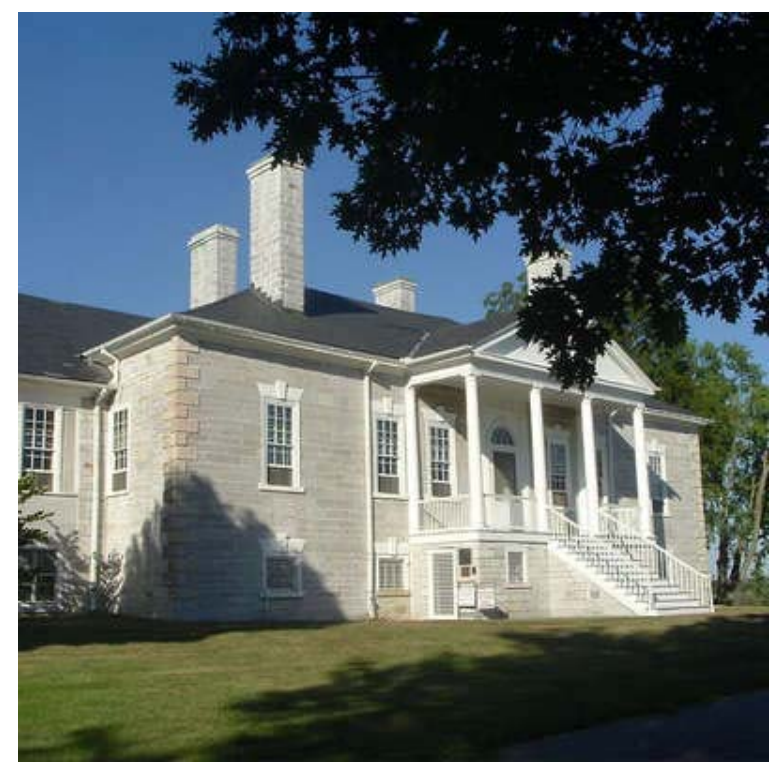

Image 14

Belle Grove Plantation, 1797 near Middletown, Virginia

(http://www.visitshenandoah.org/v.php?pg=453) 


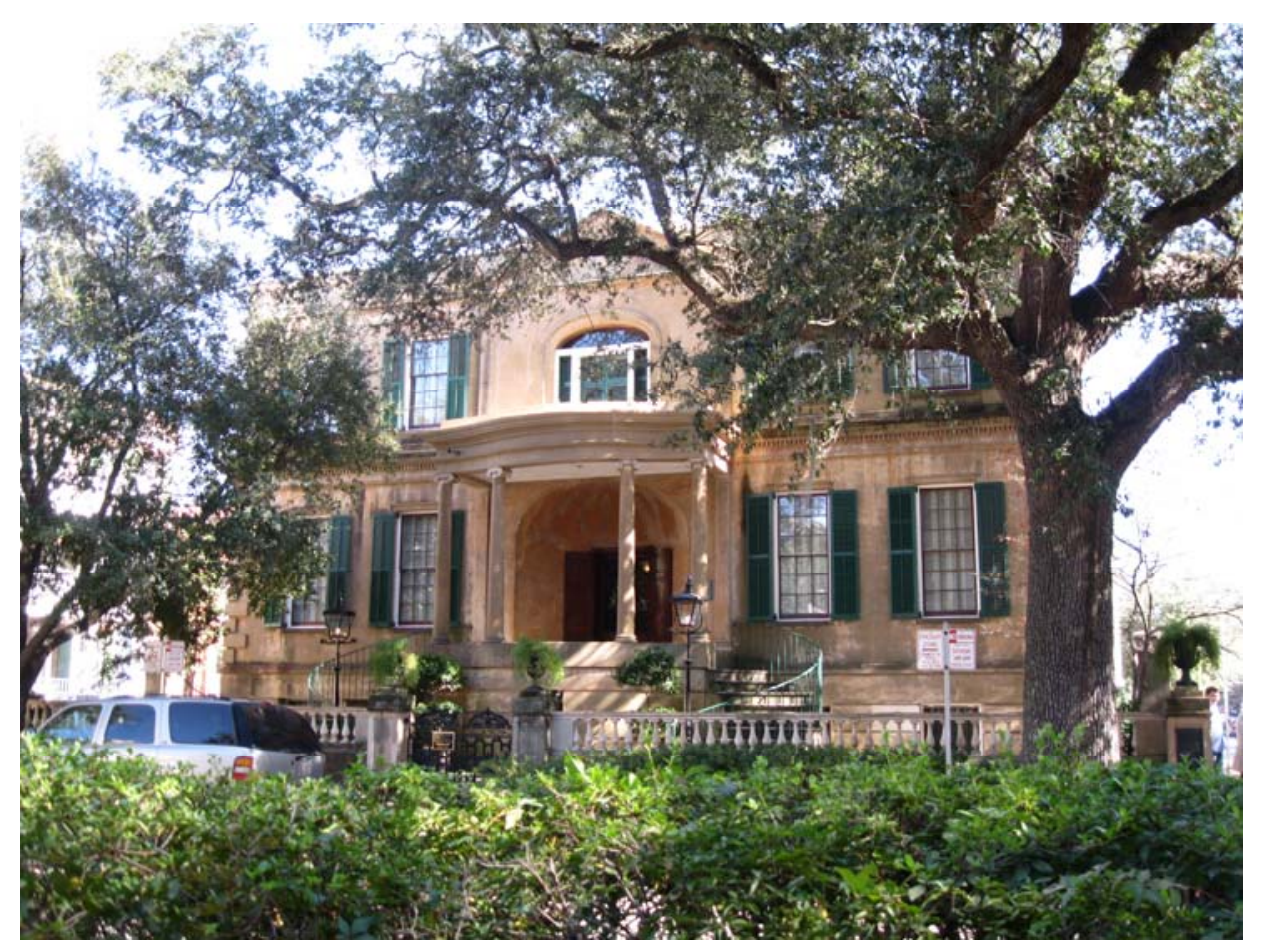

Image 15

Owens-Thomas House, 1816-1819

William Jay

Savannah, Georgia

(photograph by author)

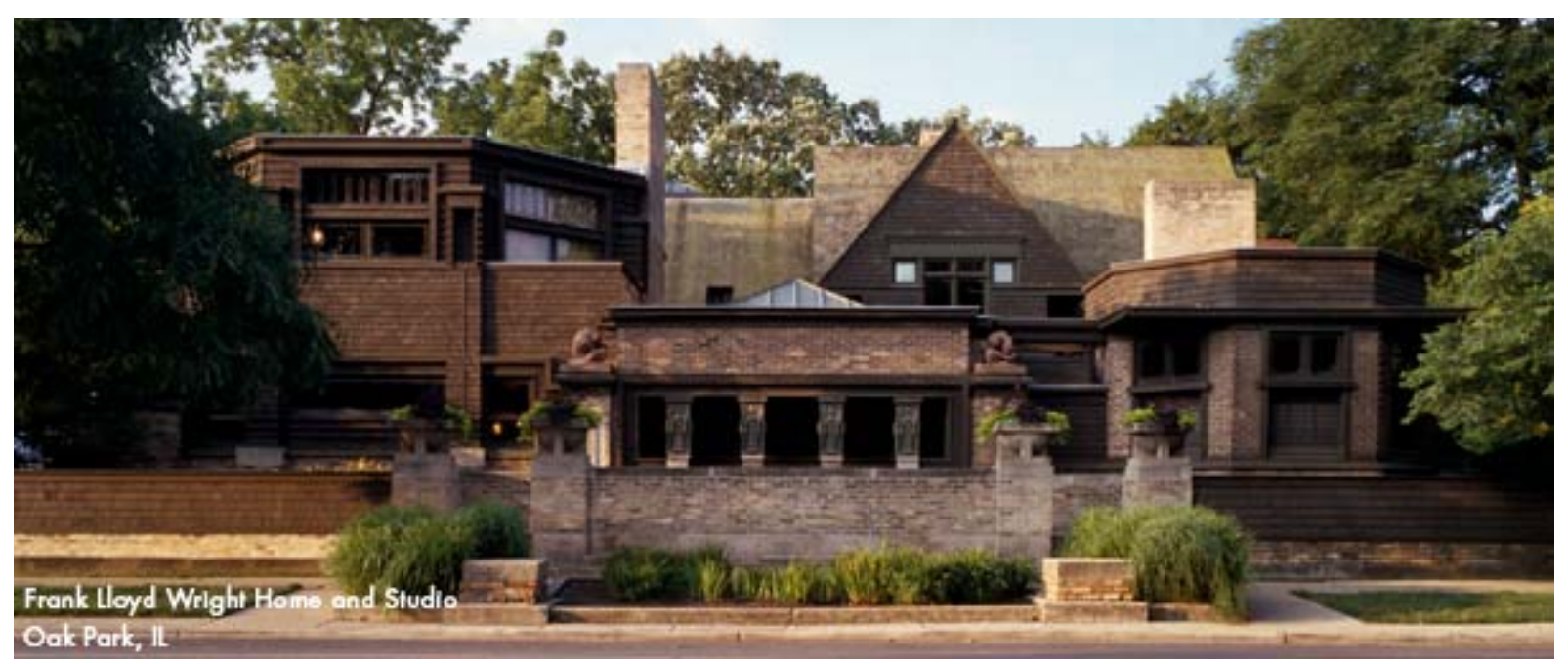

\section{Image 16}

Wright Home and Studio, 1889-98

Frank Lloyd Wright

Oak Park, Illinois

(gowright.org) 


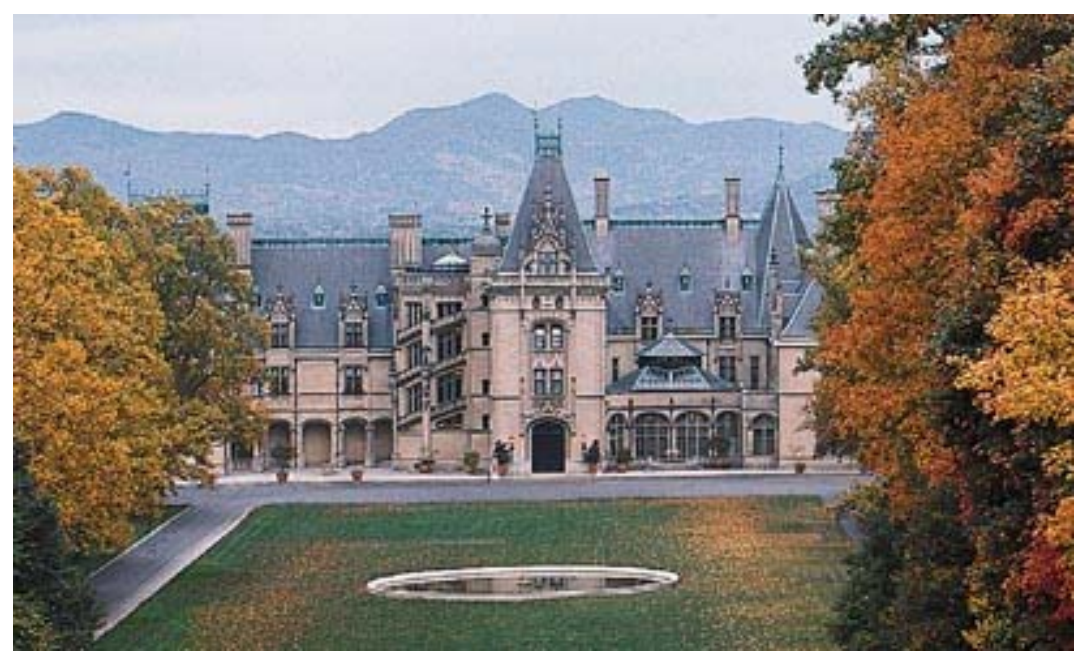

Image 17

Biltmore Estate, 1889-95

Richard Morris Hunt

Ashville, North Carolina

(http://www.biltmorevillage.com/BiltmoreEstate.htm)

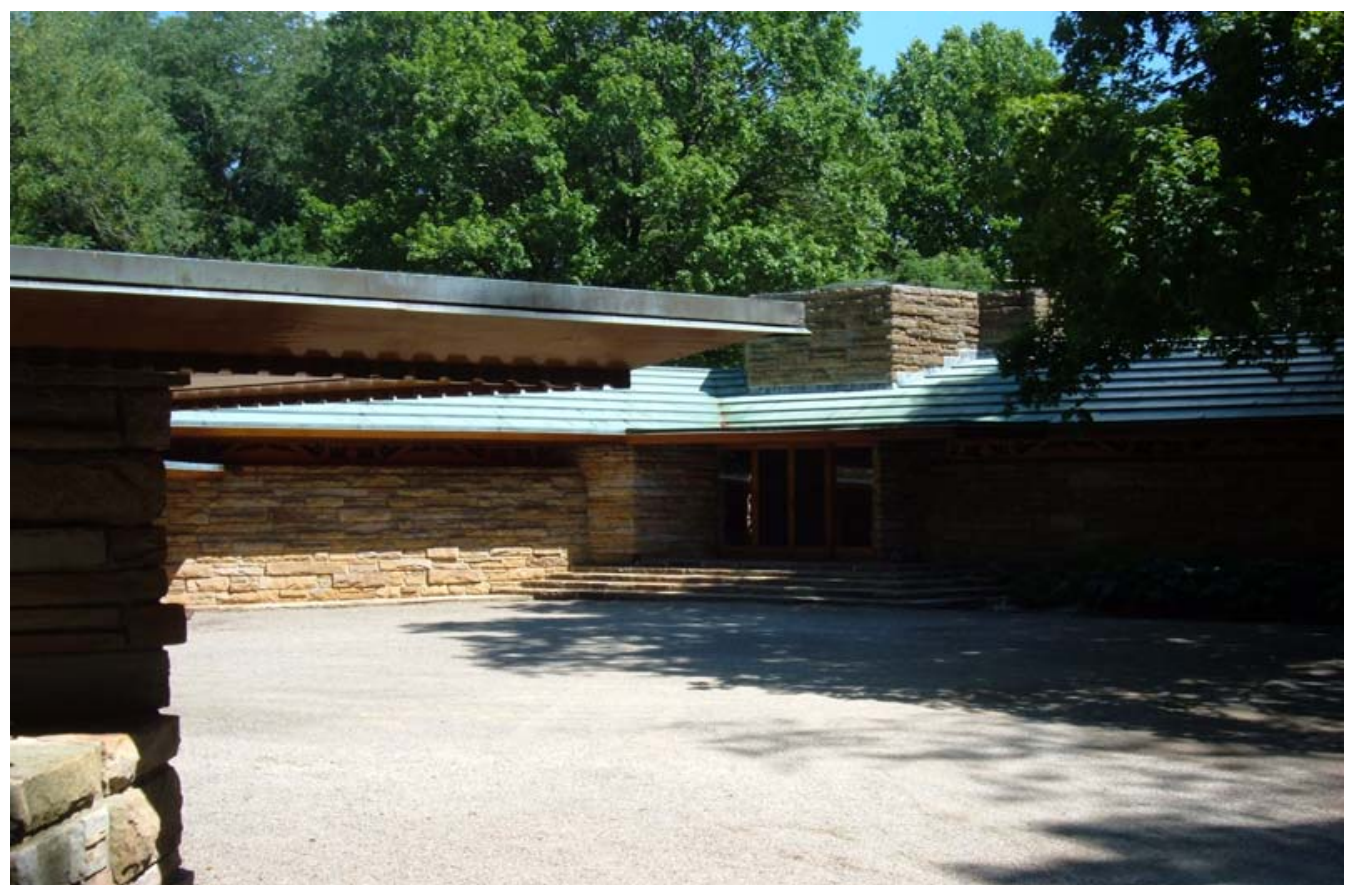

Image 18

Kentuck Knob, 1953-56

Frank Lloyd Wright

Chalk Hill, Pennsylvania

(photograph by author) 


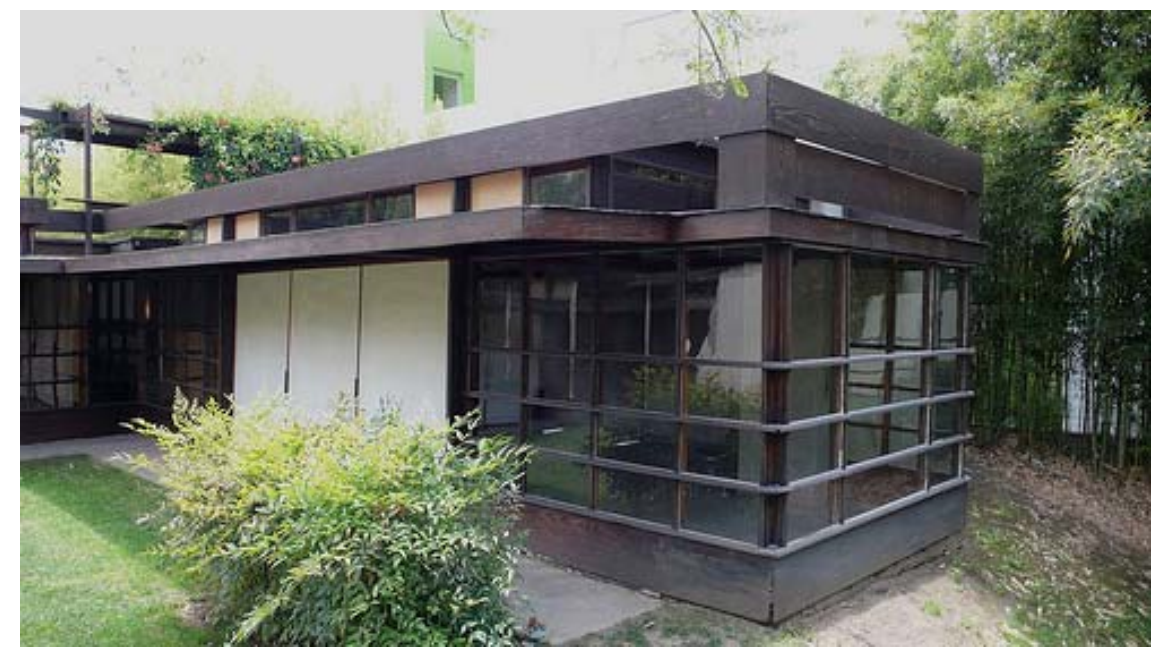

Image 19

The Schindler House, 1922

Rudolf Schindler

West Hollywood, California

(http://autobiographicalhouses.wordpress.com/2011/02/01/schindler-house/)

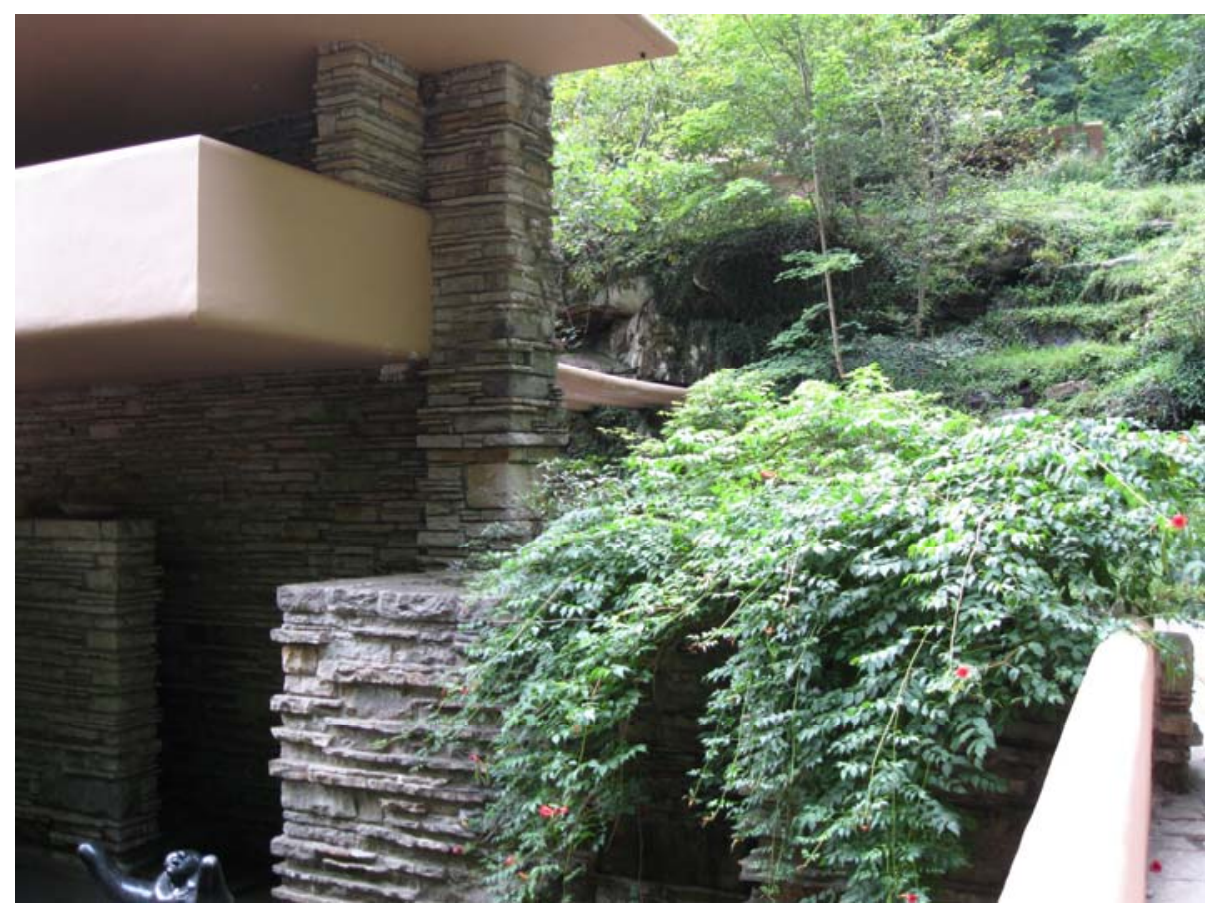

Image 20

Fallingwater from bridge, 2934-1939

Frank Lloyd Wright

Mill Run, Pennsylvania

(photograph by author) 


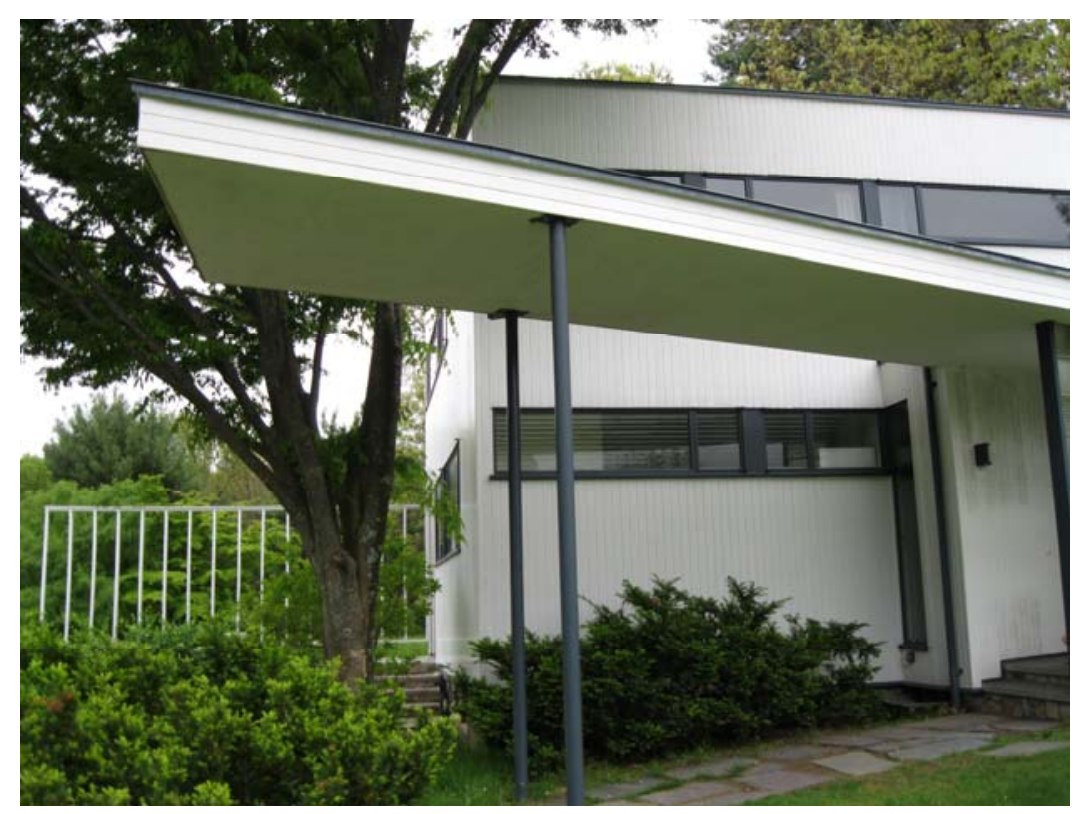

Image 21

The Gropius House entrance, 1938

Walter Gropius

Lincoln, Massachusetts

(photograph by author)

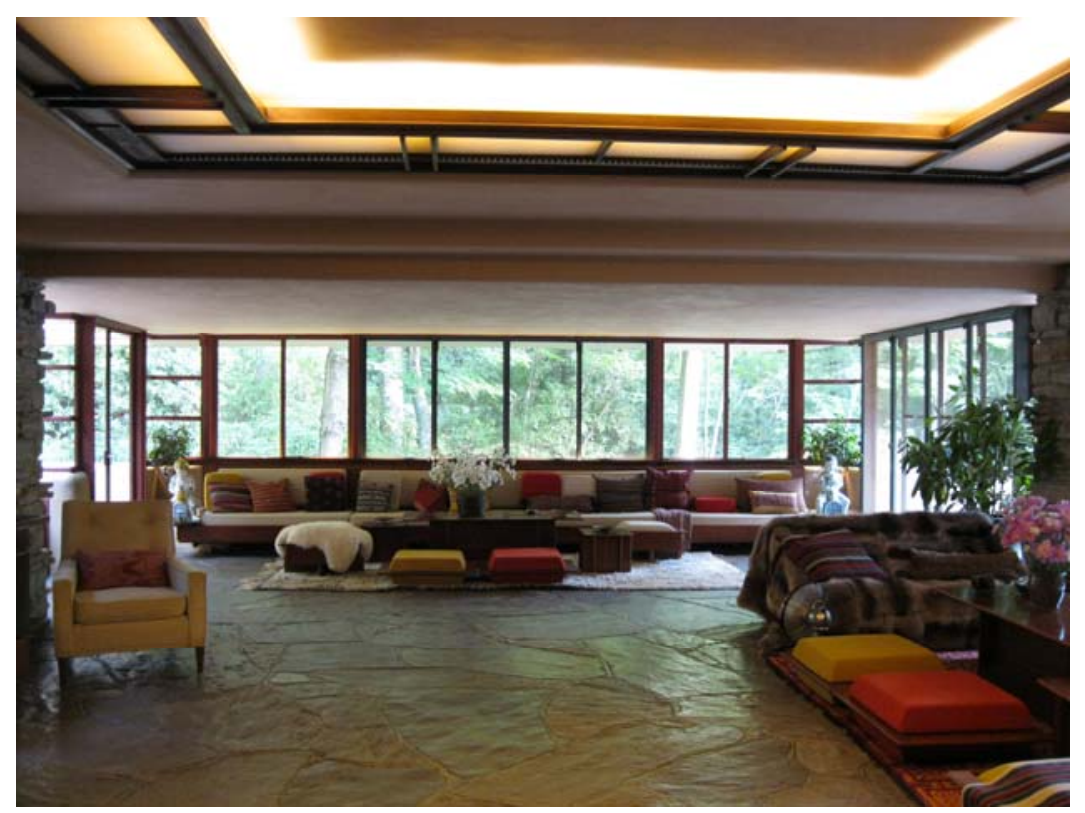

Image 22

Fallingwater living room, 1934-1939

Frank Lloyd Wright

Mill Run, Pennsylvania

(photograph by author) 


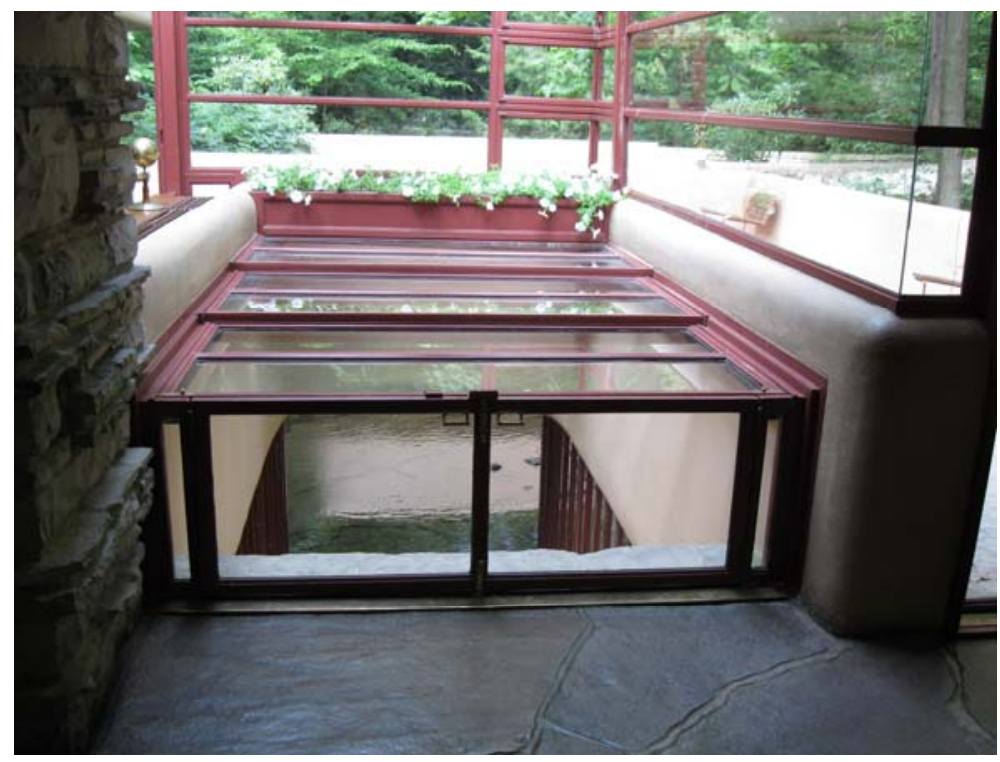

Image 23

Fallingwater hatch in living room, 1934-1939

Frank Lloyd Wright

Mill Run, Pennsylvania

(photograph by author)

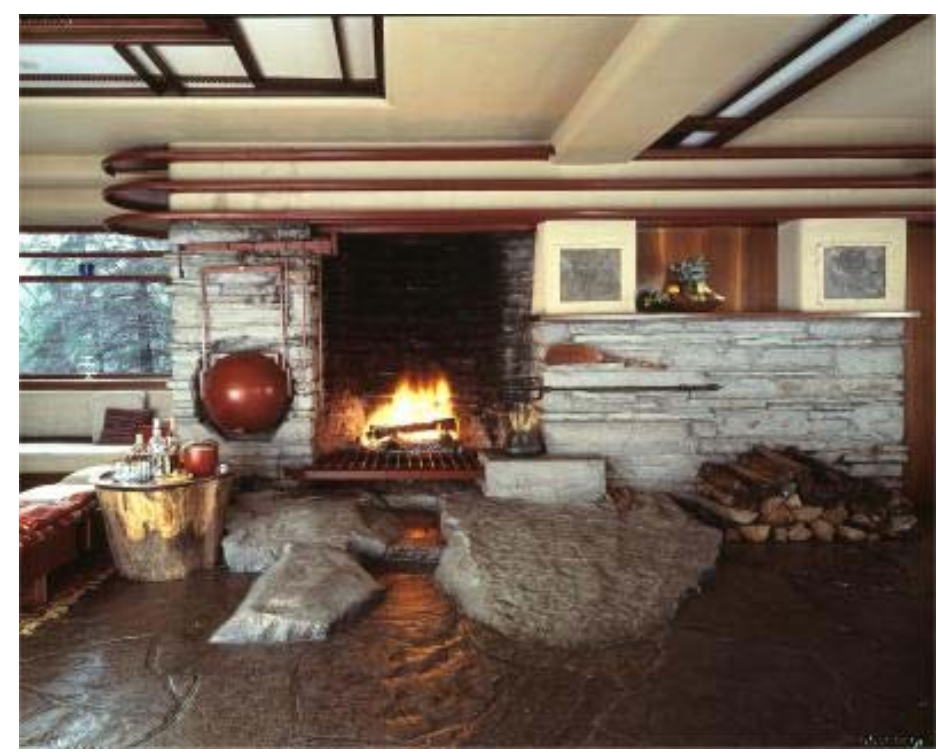

\section{Image 24}

Fallingwater fireplace in living room, 1934-1939

Frank Lloyd Wright

Mill Run, Pennsylvania

(http://pittsburgh.about.com/cs/pictures/l/bl_flw_2.htm) 


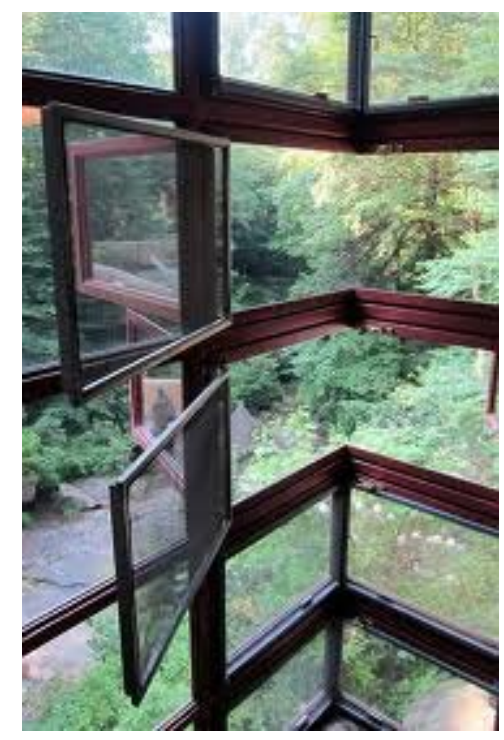

Image 25

Fallingwater windows in Edgar Kaufmann, Sr.'s bedroom, 1934-1939

Frank Lloyd Wright

Mill Run, Pennsylvania

(http://www.flickr.com/photos/wallyg/6043873342/)

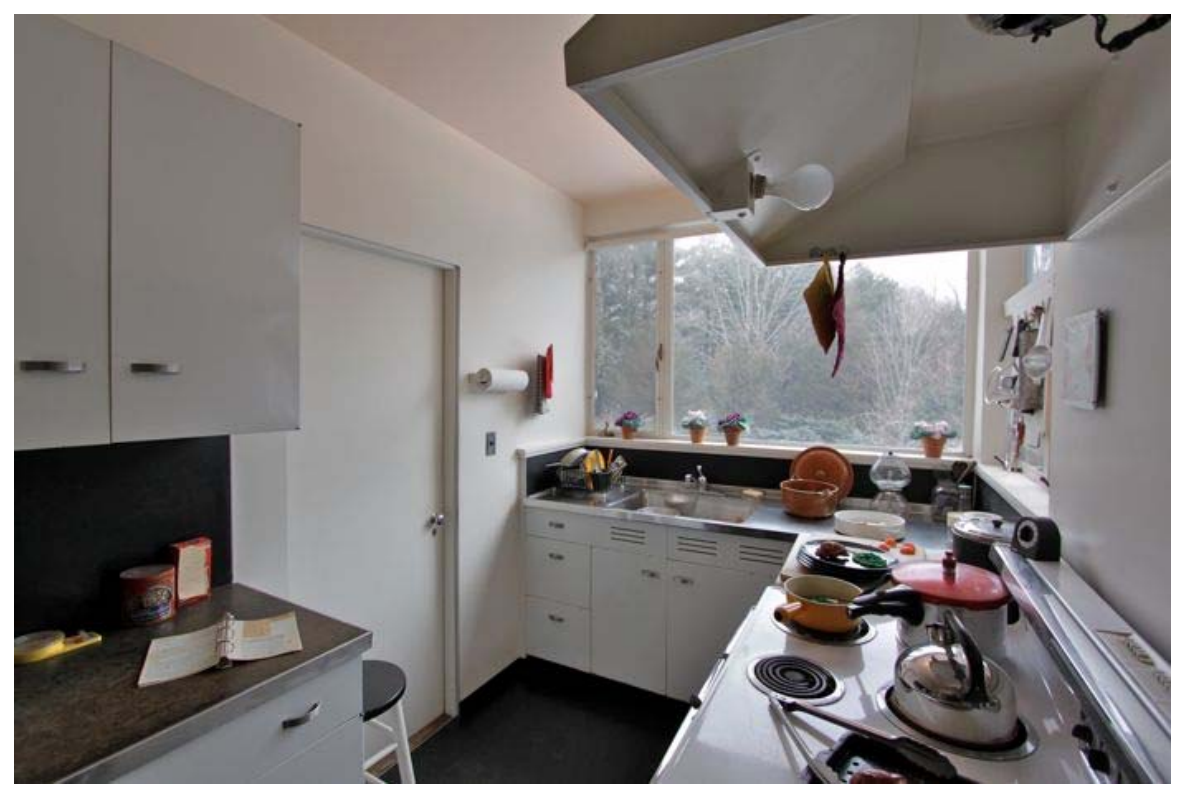

Image 26

The Gropius House kitchen, 1938

Walter Gropius

Lincoln, Massachusetts

(http://www.historicnewengland.org/historic-properties/homes/Gropius\%20House/gropiushouse) 


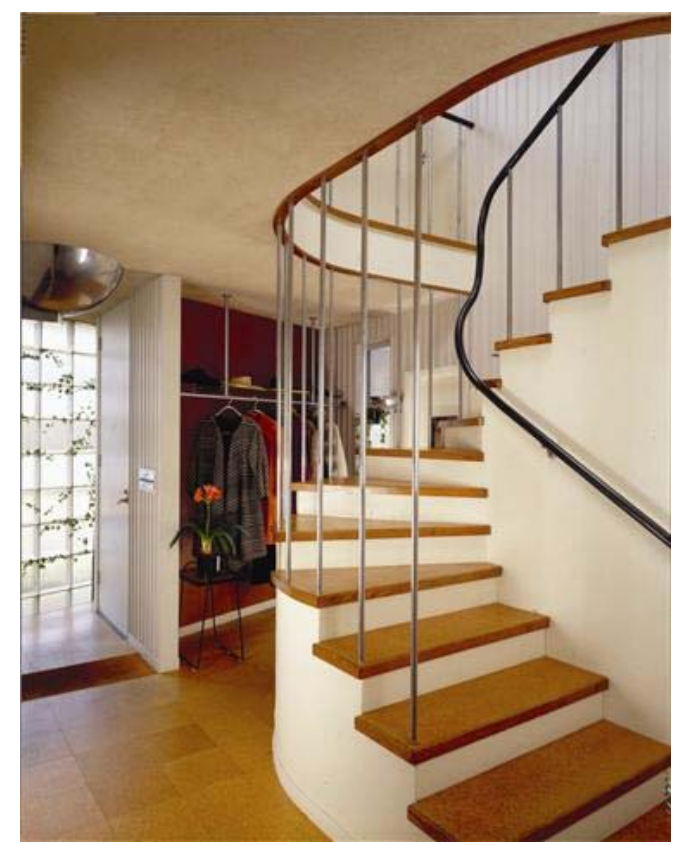

Image 27

The Gropius House entry, 1938

Walter Gropius

Lincoln, Massachusetts

(http://www.historicnewengland.org/historic-properties/homes/Gropius\%20House/gropiushouse)

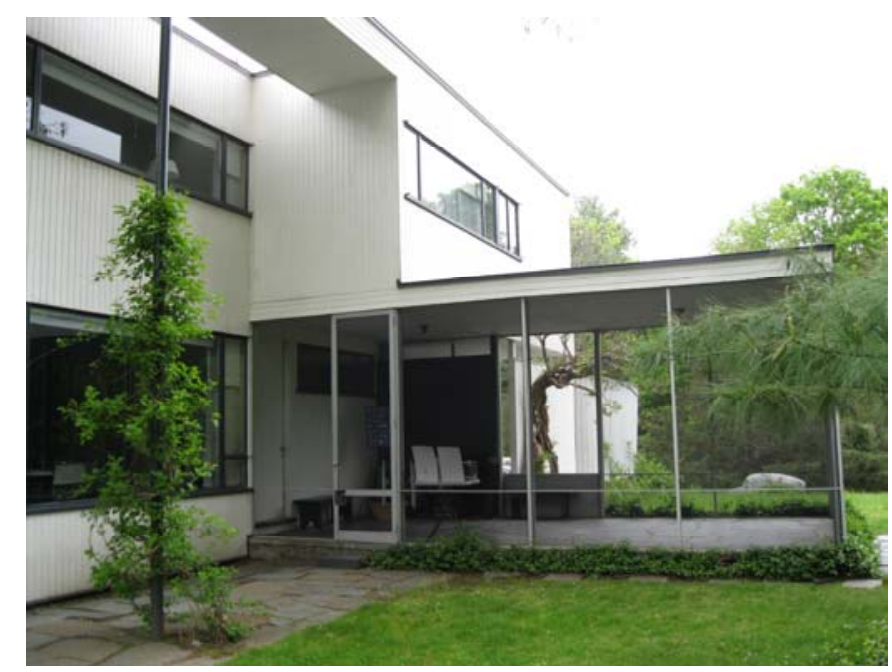

Image 28

The Gropius House screened back porch, 1938

Walter Gropius

Lincoln, Massachusetts

(photograph by author) 


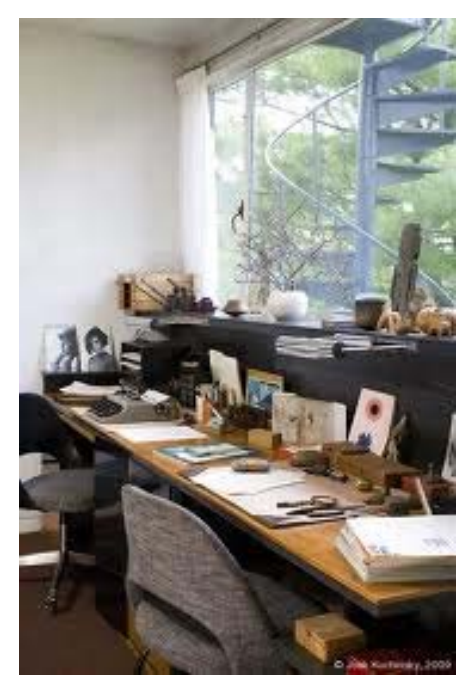

Image 29

The Gropius House office, 1938

Walter Gropius

Lincoln, Massachusetts

(http://www.historicnewengland.org/historic-properties/homes/Gropius\%20House/gropiushouse)

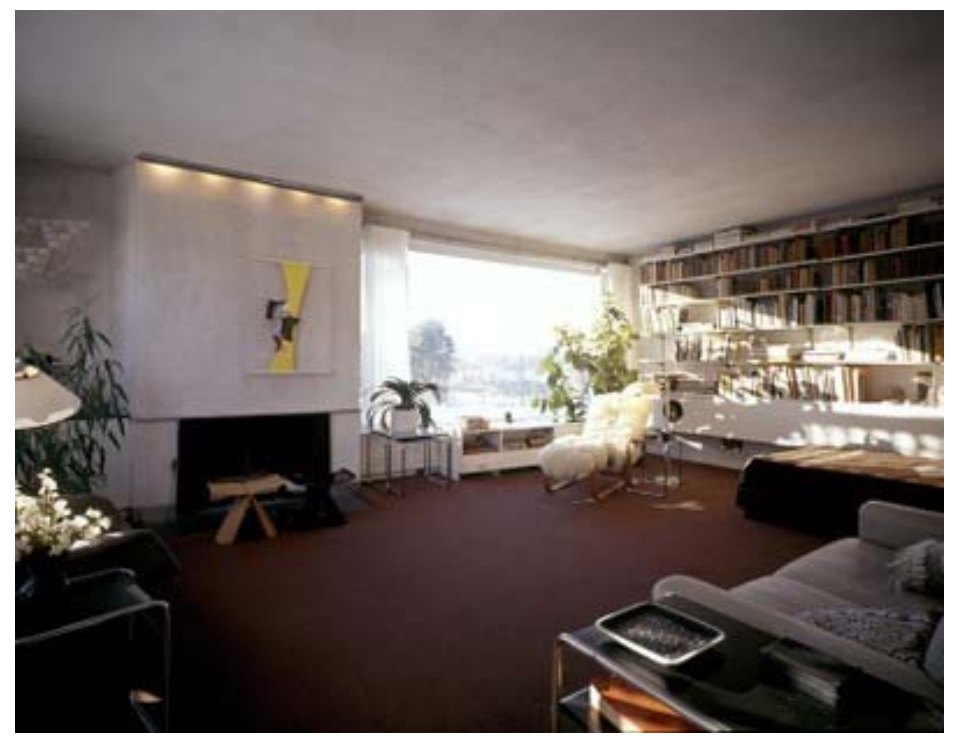

Image 30

The Gropius House living room, 1938

Walter Gropius

Lincoln, Massachusetts

(http://www.historicnewengland.org/historic-properties/homes/Gropius\%20House/gropiushouse) 


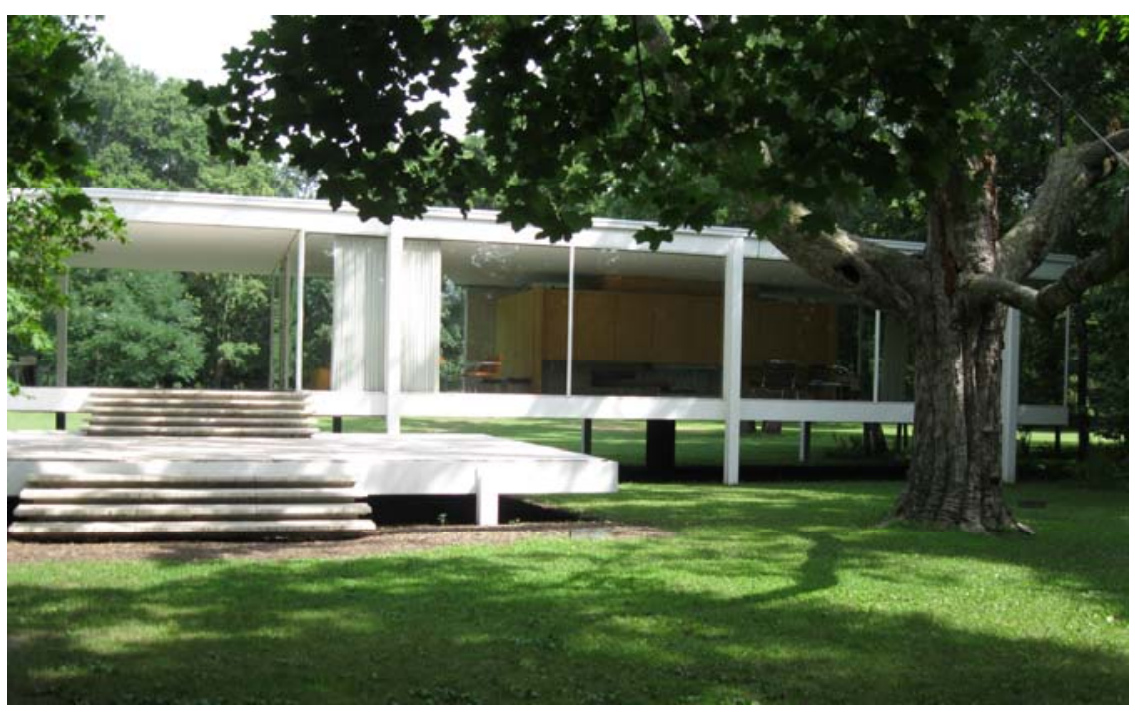

\section{Image 31}

The Farnsworth House, 1951

Ludwig Mies van der Rohe

Plano, Illinois

(photograph by author)

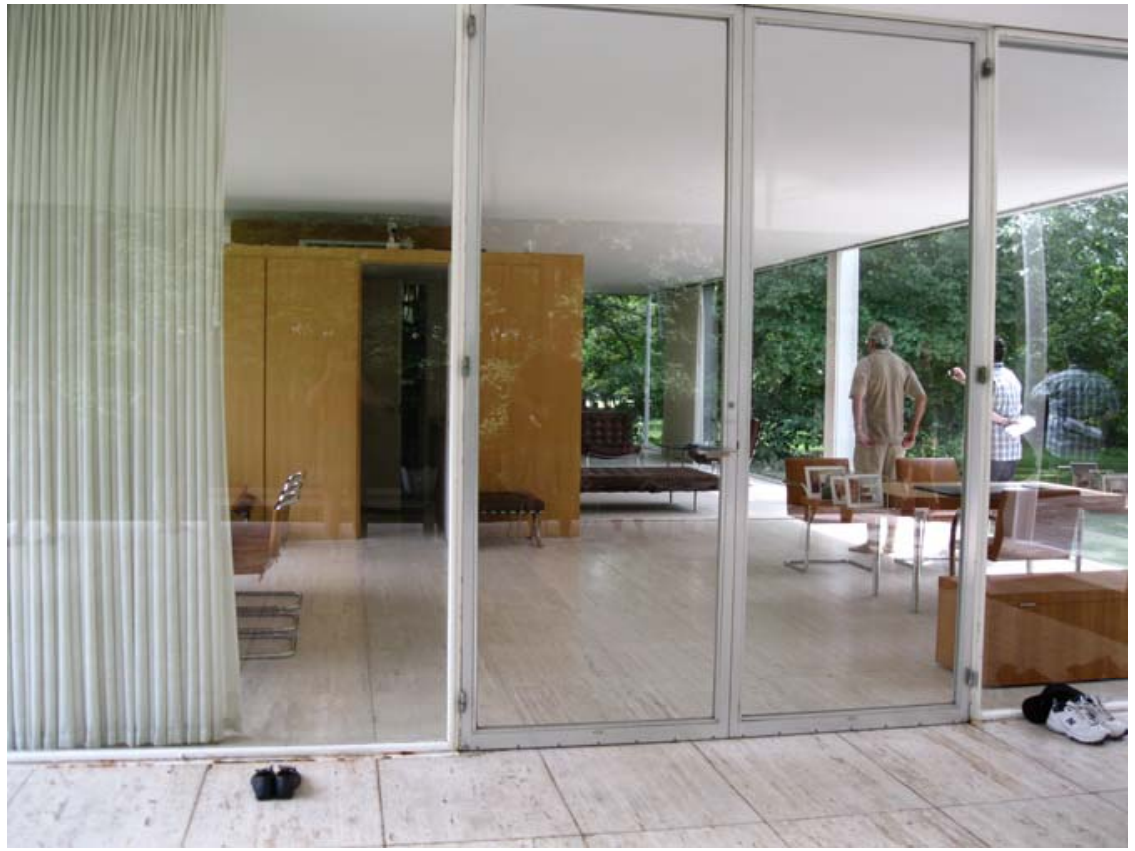

Image 32

The Farnsworth House entrance, 1951

Ludwig Mies van der Rohe

Plano, Illinois

(photograph by author) 


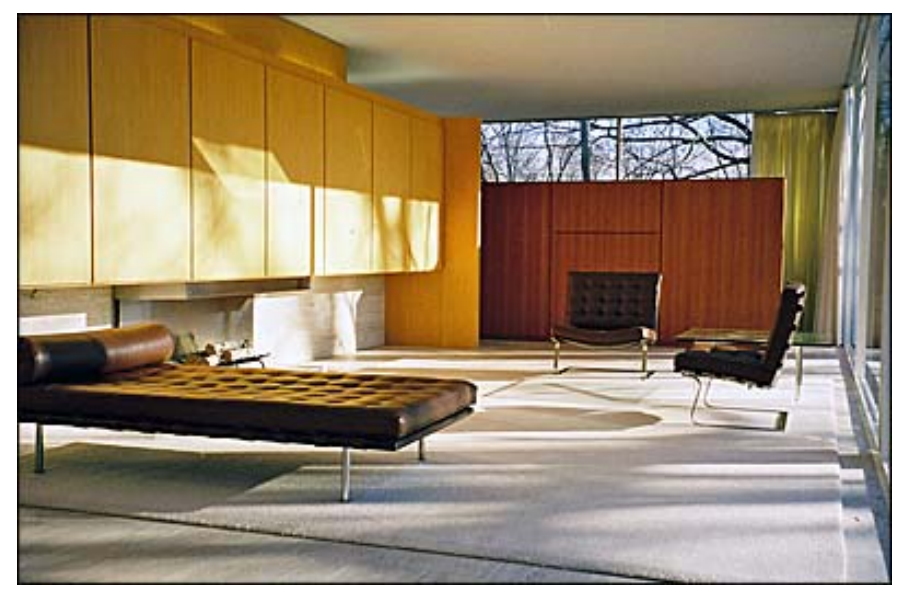

Image 33

The Farnsworth House living room, 1951

Ludwig Mies van der Rohe

Plano, Illinois

(farnsworthhouse.org)

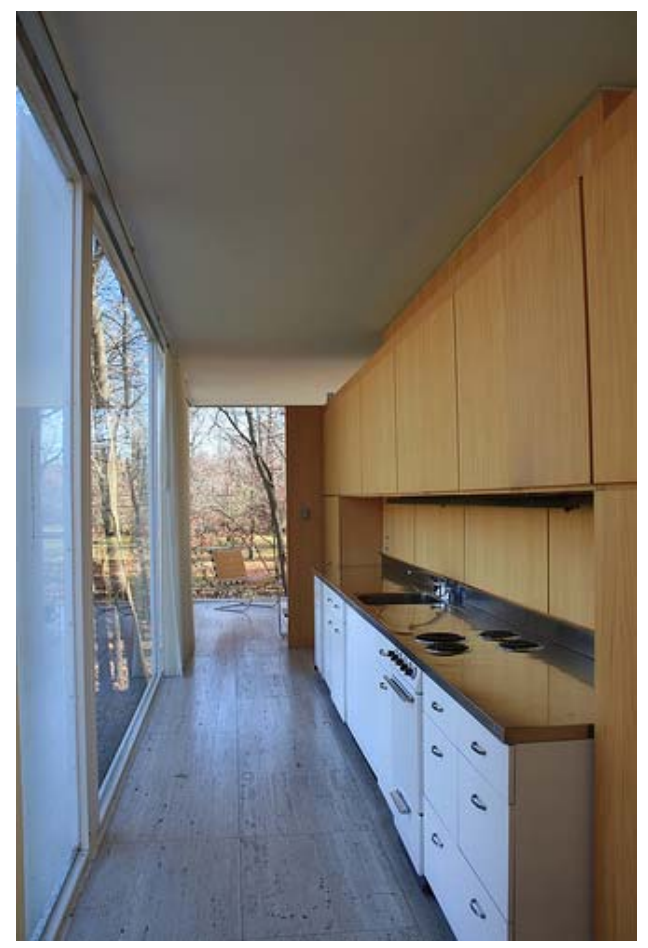

\section{Image 34}

The Farnsworth House kitchen, 1951

Ludwig Mies van der Rohe

Plano, Illinois

(farnsworthhouse.org) 


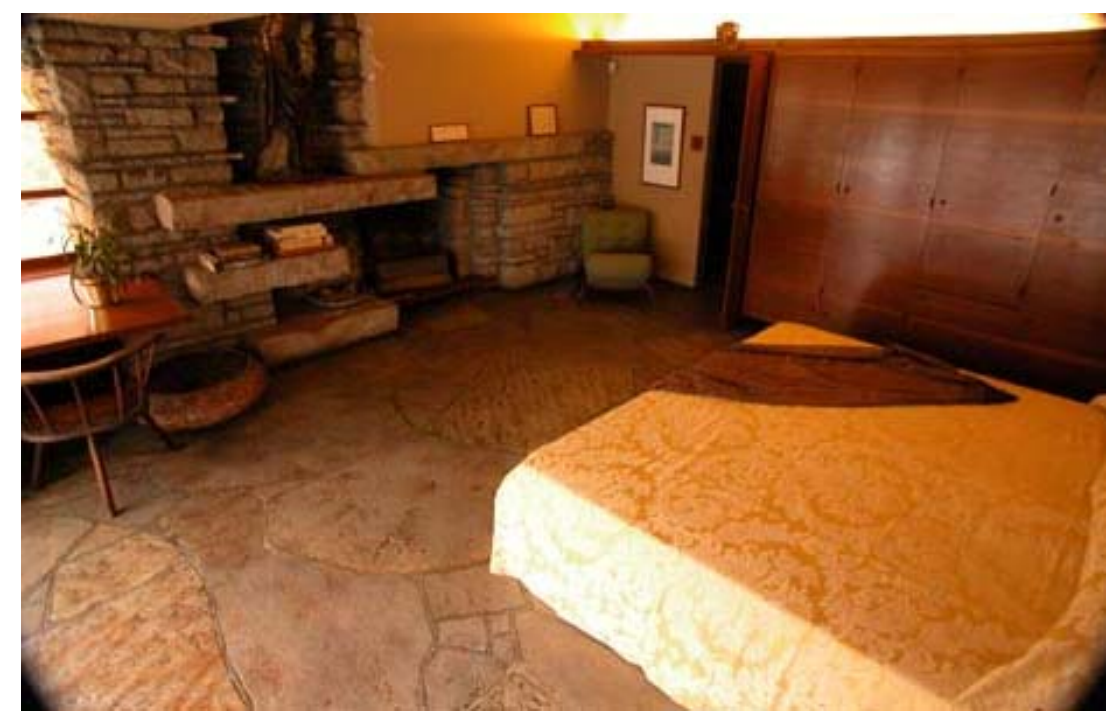

Image 35

Fallingwater Liliane Kaufmann’s bedroom, 1934-1939

Frank Lloyd Wright

Mill Run, Pennsylvania

(http://www.peterbeers.net/interests/flw_rt/Pennsylvania/Falling_Water/march_2003/fallingwate

r_march_2003.htm)

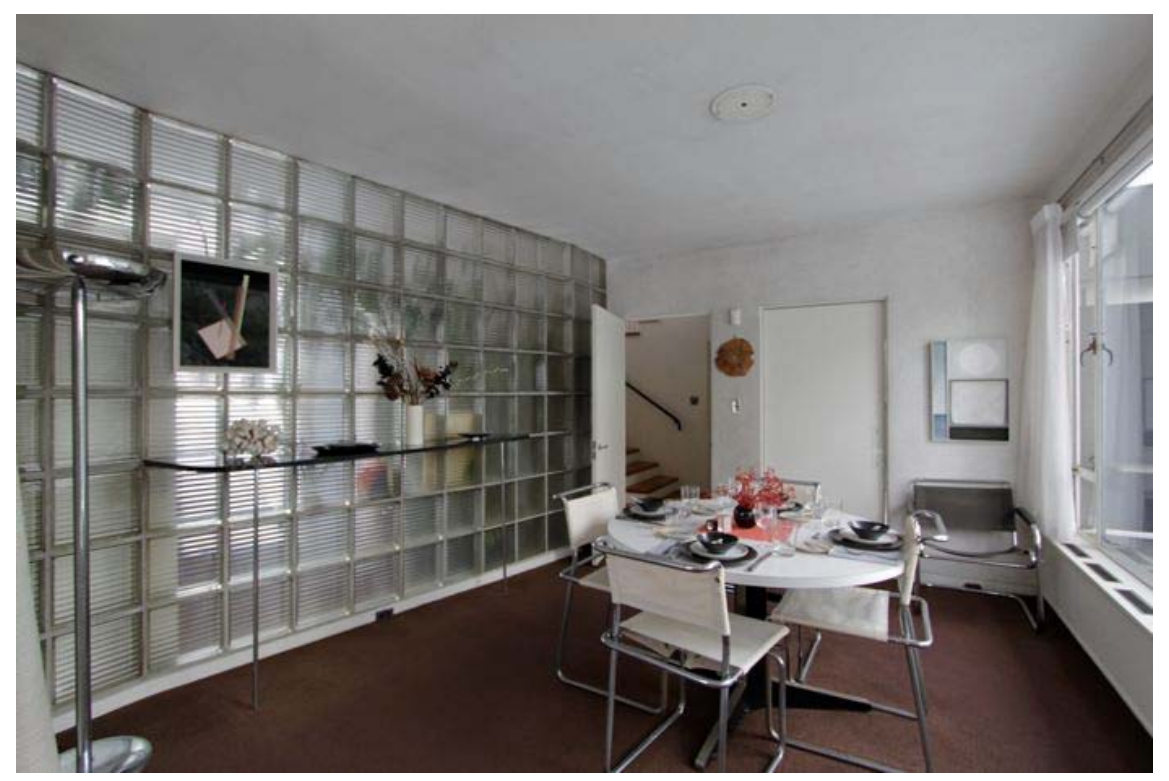

\section{Image 36}

The Gropius House dining room, 1938

Walter Gropius

Lincoln, Massachusetts

(http://www.historicnewengland.org/historic-properties/homes/Gropius\%20House/gropiushouse) 


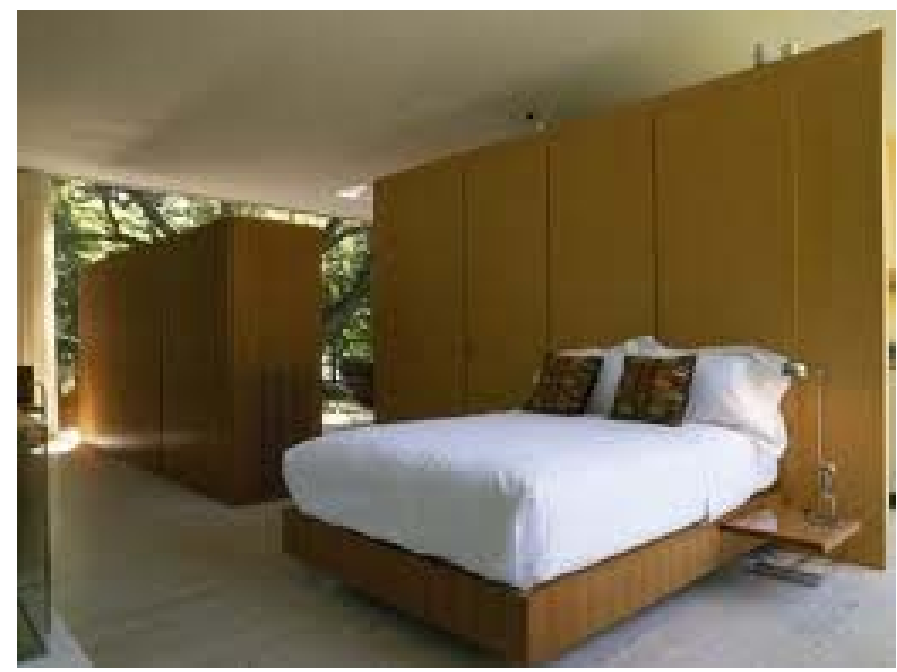

Image 37

The Farnsworth House bedroom, 1951

Ludwig Mies van der Rohe

Plano, Illinois

(farnsworthhouse.org)

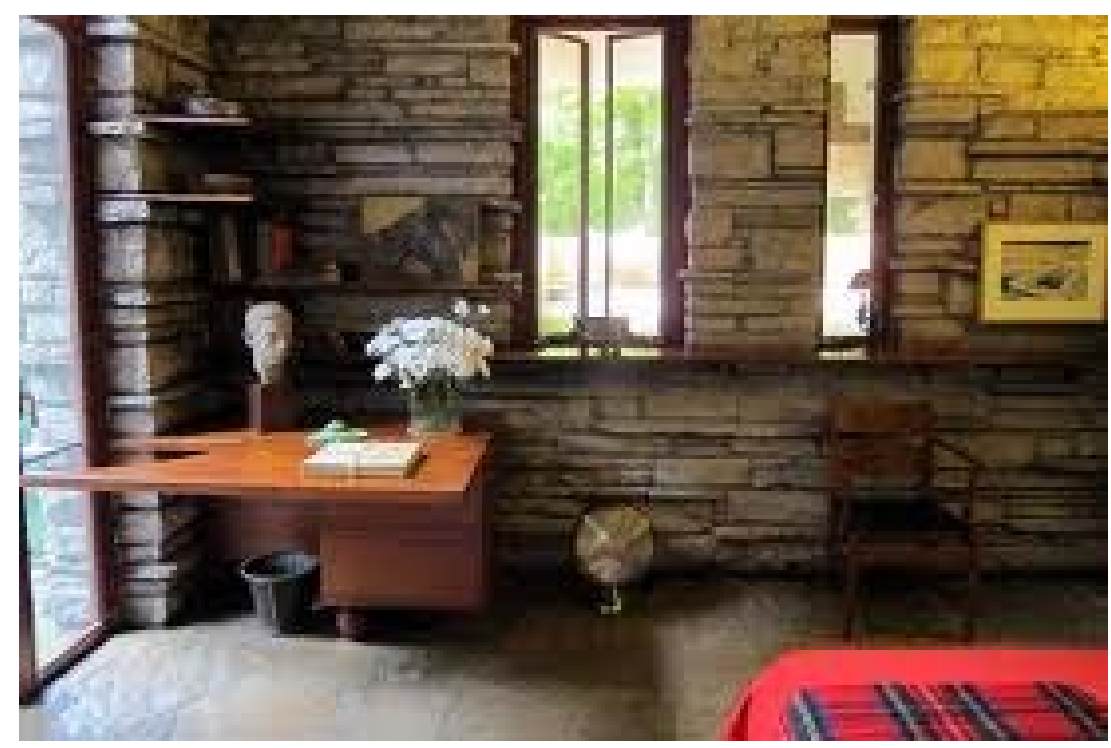

Image 38

Fallingwater Edgar Kaufmann, Sr.'s bedroom, 1934-1939 Frank Lloyd Wright

Mill Run, Pennsylvania

(http://www.flickr.com/photos/wallyg/6043323005/) 


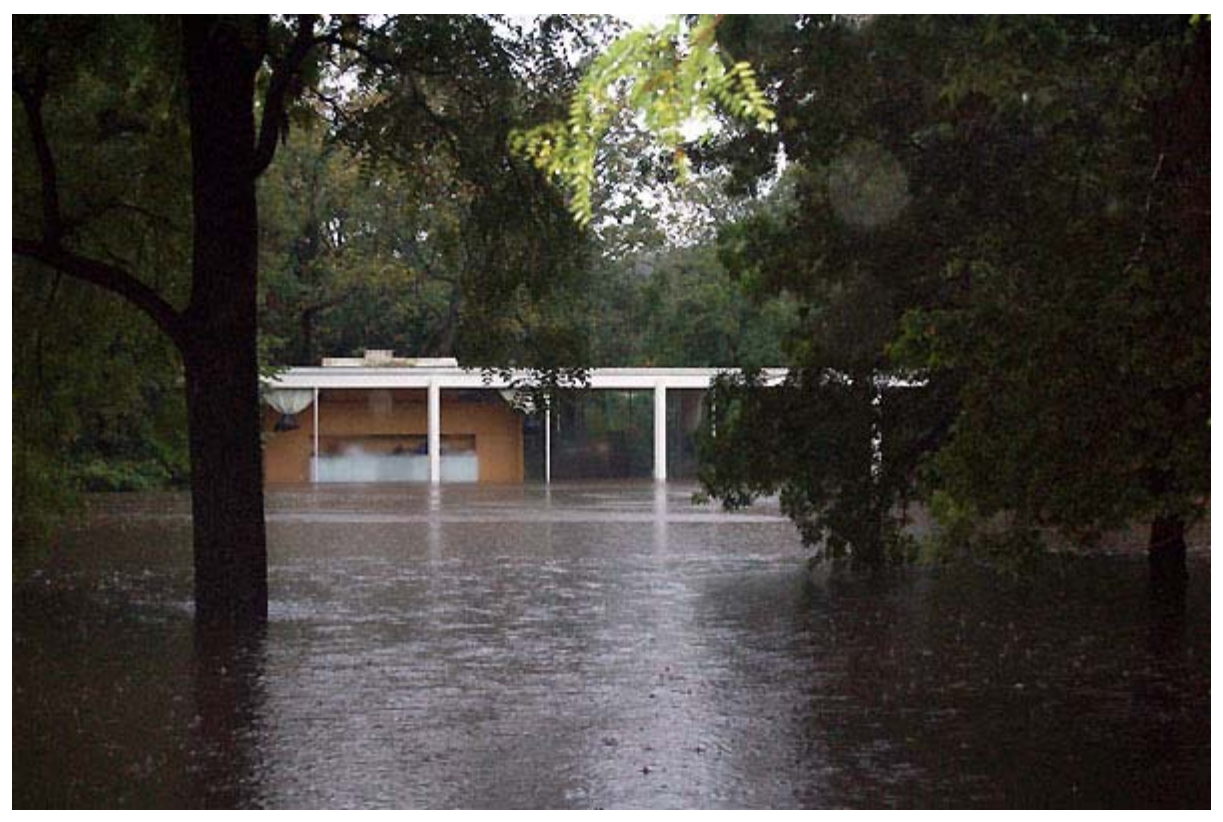

Image 39

The Farnsworth House flood 2008

(http://www.preservationnation.org/magazine/2008/todays-news/farnsworth-house-floods.html) 


\section{Bibliography}

Agnese, Braulio. “Farnsworth House Flooded.” Architect 97, no. 13 (2008): 22.

Berg, Lisa. Conversation with author, Chalk Hill, PA. March 2011.

Belle Grove Plantation, “About Us,” http://www.bellegrove.org/index.php?/about (accessed March 11, 2012).

Blake, Peter. The Master Builders: Le Corbusier, Mies van der Rohe, Frank Lloyd Wright. New York: The Norton Library, 1976.

Buck, Susan L. "A Material Evaluation of the Gropius House: Planning to Preserve a Modern Masterpiece.” APT Bulletin 28, no.4 (1997): 29-35.

Butcher-Younghans, Sherry. Historic House Museums: A Practical Handbook for their Care, Preservation, and Management. New York: Oxford University Press, 1993.

Cleary, Richard L. Merchant Prince and Master Builder. Pittsburgh: The Heinz Architectural Center, 1999.

Cloonan, Michele V. “The Boundaries of Preservation and Conservation Research.” Libraries \& the Cultural Record 46, no. 2 (2011): 220-9.

Commisso, Michael, H. Eliot Foulds. Land Use History for Cedar Creek and Belle Grove National Historical Park. Boston: National Park Service, 2007.

Covington, Howard E., Jr. Lady on the Hill. Hoboken: John Wiley and Sons, Inc., 2006.

Curtis, Nancy. "Historic Houses.” Humanities 18, no.1 (1997): 16-9.

De Long, David G. Frank Lloyd Wright: Designs for an American Landscape 1922-1932. Washington D.C.: Library of Congress, 1996.

Donnelly, Jessica Foy. Interpreting House Museums. Lanham, MD: AltaMira Press, 2003.

Fallingwater Interpretive Manual, revised 2009. Courtesy of the Western Pennsylvania Conservancy

Fallingwater Tour. Mill Run, Pennsylvania, March 18, 2011.

Farnsworth House Tour. Plano, Illinois, August 2, 2011.

Fitch, James Marston. Walter Gropius. New York: George Braziller, Inc., 1960. 
Flemming, John, Hugh Homour, Nikolaus Pevsner. The Penguin Dictionary of Architecture and Landscape Architecture. London: Penguin Books, 1999.

Freeman, A. "Open Houses- Two Modern Masterpieces Stand for all to see: The 1938 Gropius House in Lincoln, Mass., and Mies van der Rohe's 1951 Farnsworth House in Illinois." PRESERVATION 53, no.5 (2001): 20.

French, Whitney. Conversation with author, Plano, Illinois, August 2, 2011.

Gentle, Thom, and Victoria Jefferies. “Conservation of Furniture at Frank Lloyd Wright's Fallingwater. APT Bulletin 21, no.3/4 (1989): 55-61.

Gittleman, Peter. “The Spirit of the House.” Historic New England Magazine (Fall 2002): http://www.historicnewengland.org/publications/historic-new-england-magazine/fall2002/2002FallPage01.htm/?searchterm=ati\%20gropius

Gittleman, Peter and Wendy Hubbard. Conversation with author, Lincoln, Illinois, May 23, 2011.

Gropius House Tour. Lincoln, Massachusetts, May 22, 2011.

Gropius House Tour Outline. Courtesy of Historic New England.

Gropius House website. http://www.historicnewengland.org/historicproperties/homes/Gropius\%20House (accessed March 11, 2012).

Gunther, Justin. Conversations with author, Mill Run, Pennsylvania, from June 2010- August 2011.

Gunther, Justin. Fallingwater Preservation Manual. Courtesy of the Western Pennsylvania Conservancy.

Hale, J. “Tough Times for Wright Houses: Fallingwater and a Wing of Taliesin Need Restoration.” Architectural Record 186, no.9 (1998): 53.

Haraguchi, Hideaki. A Comparative Analysis of $20^{\text {th }}$ Century Houses. New York: Rizzoli, 1988.

Hatje, Gerd. Encyclopedia of Modern Architecture. London: Thames and Hudson, 1963.

Hilberseimer, L. Mies van der Rohe. Chicago: Paul Theobald and Company, 1956.

Historic New England, “About Us,” http://www.historicnewengland.org/about-us (accessed March 4, 2011).

Hoffmann, Donald. Frank Lloyd Wright's Fallingwater: The House and its History. New York: Dover Publications, Inc., 1978. 
Hoffmann, Donald. Frank Lloyd Wright's House Kentuck Knob. Pittsburgh: University of Pittsburgh Press, 2000.

Jerome, Pamela, Norman Weiss, and Hazel Ephron. “Fallingwater Part 2: MaterialsConservation Efforts at Frank Lloyd Wright's Masterpiece. APT Bulletin 37, no.2/3 (2006): 3-11.

Johnson, Philip C. Mies van der Rohe. New York: The Museum of Modern Art, 1947.

Johansen, Ati Gropius. “Designed for Living.” Historic New England Magazine (Fall 2003): http://www.historicnewengland.org/publications/historic-new-england-magazine/fall2003/2003FallPage02.htm/?searchterm=ati\%20gropius

Kaufmann, Edgar Jr. “Edited Text of Fallingwater Discussion: 31 May 1974.” Western Pennsylvania Conservancy Archives, Fallingwater Mill Run, Pennsylvania.

Kaufmann, Edgar Jr. “Edgar Kaufmann Jr. tour of Fallingwater: April 1985.” Western Pennsylvania Conservancy Archives, Fallingwater Mill Run, Pennsylvania.

Kaufmann, Edgar Jr. "Remarks on Fallingwater as Administered by the Western Pennsylvania Conservancy.” Western Pennsylvania Conservancy Archives, Fallingwater Mill Run, Pennsylvania.

Kay, Jane Holtz. “The Gropius House: Renovating A Modern Classic.” New York Times (December 1, 1988): 1.

Kilpatrick, John A., and Victoria B. Adams. "Preservation Easements.” Journal of Wealth Management (2008): 11.

Kramer, EF. “The Walter Gropius House Landscape: A Collaboration of Modernism and the Vernacular.” Journal of Architectural Education 57, no.3 (2004): 39-47.

Lambros, G. "Much Ado about Almost Aothing: Lord Peter Palumbo Rescues Mies van der Rohe's Elegant Farnsworth House.” Preservation 52, no.5 (2000): 64-7.

Levy, Barbara Abramoff, Sandra Mackenzie Lloyd, and Susan Porter Schreiber. Great Tours! Thematic Tours and Guide Training for Historic Sites New York: Alta Mira Press, 2001.

Lindgren, James Michael. Preserving Historic New England: Preservation, Progressivism, and the Remaking of Memory. New York: Oxford University Press (1995).

Lubell, Sam. “Farnsworth House Saved. Architectural Record 192, no.1 (2004): 157. 
Meyer, Kimberli. "The MAK Center at the Schindler House: Taking Cues from a Modern Experimentalist.” Presentation at Private Domains, Public Displays: The Modern House Museum Interpreted symposium. Pittsburgh, PA, April 5, 2011.

Nance, Kevin. "Preservation Heroes 'Landmarked': Event to Benefit Mies' Famous Farnsworth House” Chicago Sun-Times (February 13, 2007): 36.

National Trust for Historic Preservation "About Us.” http://www.preservationnation.org/aboutus/ (accessed March 2, 2012)

Neuwirth, Jessica, Robert Paynter, Kevin Sweeny, Braden Paynter, and Abbott Lowell Cummings. "Abbott Lowell Cummings and the Preservation of New England." The Public Historian 29, no.4 (2007): 57-81.

Norberg-Schulz, Christian. Principles of Modern Architecture. London: Andreas Papadakis Publisher, 200.

O’Connell, Kim A. “Modern Marvels,” Period Homes (November 2007).

Scott, Judith. Preservation of Gropius House, April 1, 2003. Courtesy of Historic New England.

Schulze, Franz. Mies van der Rohe: A Critical Biography. Chicago: The University of Chicago Press, 1985.

Secretary of the Interior's Standards for the Treatment of Historic Properties. http://www.nps.gov/hps/tps/standguide/overview/using_standguide.htm (accessed November 21, 2011).

Sharp, Dennis. Bauhaus, Dessau: Walter Gropius. London: Phaidon Press Limited, 1993.

Storrer, William Allin. The Architecture of Frank Lloyd Wright. The Massachusetts Institute of Technology, 9174.

Strasberg, Hadiya. “A Philosophy of Respect Guided the Conservation of Greene \& Greene’s Gamble House.” Period Homes. http://www.gamblehouse.org/conservation/articles/periodhomes.html (accessed March 27, 2012).

Sullivan, Louis H. “The Tall Office Building Artistically Considered.” Lippincott's Magazine, March 1896.

Thomas Jefferson’s Monticello tour. Charlottesville, Virginia, October, 2010.

Thompson, Paulette. Telephone conversation with author, March 20, 2012.

Waggoner, Linda. Fallingwater. New York: Rizzoli, 2011. 
Weiss, Norman, Pamela Jerome, and Stephen Gottlieb. "Fallingwater Part 1: MaterialsConservation Efforts at Frank Lloyd Wright's Masterpiece.” APT Bulletin 32, no.4 (2001): 44-55.

Welsh, John. Modern House. London: Phaidon Press Limited, 1995.

West, Patricia. Domesticating History: The Political Origins of America's House Museums. Washington D.C.: Smithsonian Books, 1999.

Western Pennsylvania Conservancy “about us” http://www.paconserve.org/2/about (accessed March 2, 2012).

Western Pennsylvania Conservancy mission statement for Fallingwater. http://www.fallingwater.org/64/mission (accessed March 22, 2012).

Weston, Richard. Modernism. Phaidon Press Limited, 1996.

Zevi, Bruno. Towards an Organic Architecture. London: Faber \& Faber Limited, 1950. 